Florida International University FIU Digital Commons

3-28-2012

\title{
Development of an Integrated Surface and Subsurface Model of Everglades National Park
}

Amy Cook

Florida International University, acook@fiu.edu

DOI: $10.25148 /$ etd.FI12050240

Follow this and additional works at: https://digitalcommons.fiu.edu/etd

\section{Recommended Citation}

Cook, Amy, "Development of an Integrated Surface and Subsurface Model of Everglades National Park" (2012). FIU Electronic Theses and Dissertations. 634.

https://digitalcommons.fiu.edu/etd/634

This work is brought to you for free and open access by the University Graduate School at FIU Digital Commons. It has been accepted for inclusion in FIU Electronic Theses and Dissertations by an authorized administrator of FIU Digital Commons. For more information, please contact dcc@fiu.edu. 


\section{FLORIDA INTERNATIONAL UNIVERSITY \\ Miami, Florida}

\section{DEVELOPMENT OF AN INTEGRATED SURFACE AND SUBSURFACE MODEL OF EVERGLADES NATIONAL PARK}

A thesis submitted in partial fulfillment of the requirements for the degree of MASTER OF SCIENCE in ENVIRONMENTAL ENGINEERING by

Amy M. Cook 
To: Dean Amir Mirmiran

College of Engineering and Computing

This thesis, written by Amy M. Cook, and entitled DEVELOPMENT OF AN INTEGRATED SURFACE AND SUBSURFACE MODEL OF EVERGLADES NATIONAL PARK, having been approved in respect to style and intellectual content, is referred to you for judgment.

We have read this thesis and recommend that it be approved.

Georgio Tachiev

Walter Z. Tang

Hector R. Fuentes, Major Professor

Date of Defense: March 28, 2012

The thesis of Amy M. Cook is approved.

\begin{tabular}{r} 
Dean Amir Mirmiran \\
College of Engineering and Computing \\
\hline Dean Lakshmi N. Reddi \\
University Graduate School
\end{tabular}

Florida International University, 2012 
(C) Copyright 2012 by Amy M. Cook All rights reserved. 


\section{ACKNOWLEDGMENTS}

I thank the Department of Interior for funding the development of this hydrological model, with a special thanks to Robert Fennema and Kiren Bahm from National Park Services for providing data and contributing their time, ideas, and intimate knowledge of the Everglades National Park. It was an honor to work with them. My sincerest gratitude goes to Dr. Georgio I. Tachiev with the Applied Research Center for his guidance, training, motivation, and support throughout the model development. The opportunity to work with him has provided me with invaluable experience and skills that will stay with me throughout my professional career. My gratitude also goes to the Department of Civil and Environmental Engineering at Florida International University, specifically Dr. Hector R. Fuentes and Dr. Walter Z. Tang, for their guidance in completing this thesis. Lastly, I would like to thank my family for their unwavering encouragement and support in both my professional and personal endeavors. 


\title{
ABSTRACT OF THE THESIS \\ DEVELOPMENT OF AN INTEGRATED SURFACE AND SUBSURFACE MODEL OF EVERGLADES NATIONAL PARK
}

\author{
by \\ Amy M. Cook \\ Florida International University, 2012 \\ Miami, Florida \\ Professor Hector R. Fuentes, Major Professor
}

An integrated surface-subsurface hydrological model of Everglades National Park (ENP) was developed using MIKE SHE and MIKE 11 modeling software. The model has a resolution of 400 meters, covers approximately 1050 square miles of ENP, includes 110 miles of drainage canals with a variety of hydraulic structures, and processes hydrological information, such as evapotranspiration, precipitation, groundwater levels, canal discharges and levels, and operational schedules. Calibration was based on time series and probability of exceedance for water levels and discharges in the years 1987 through 1997. Model verification was then completed for the period of 1998 through 2005. Parameter sensitivity in uncertainty analysis showed that the model was most sensitive to the hydraulic conductivity of the regional Surficial Aquifer System, the Manning's roughness coefficient, and the leakage coefficient, which defines the canal-subsurface interaction. The model offers an enhanced predictive capability, compared to other models currently available, to simulate the flow regime in ENP and to forecast the impact of topography, water flows, and modifying operation schedules. 


\section{TABLE OF CONTENTS}

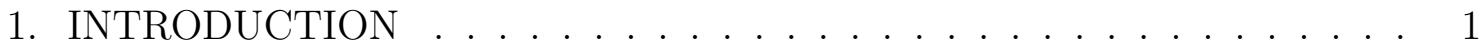

2. BACKGROUND OF THE STUDY AREA . . . . . . . . . . . . 3

2.1 Hydrogeology . . . . . . . . . . . . . . . . . . . . . 3

2.2 Soil . . . . . . . . . . . . . . . . . . . . . . . . 10

2.3 Vegetation . . . . . . . . . . . . . . . . . . . . 13

3. RESEARCH JUSTIFICATION AND OBJECTIVES . . . . . . . . . . . 14

3.1 Other Models of the Study Area . . . . . . . . . . . . . . . . . 15

4. METHODOLOGY . . . . . . . . . . . . . . . . . . 18

4.1 Model Domain and Discretization . . . . . . . . . . . . . . . 18

4.2 MIKE $11 \ldots \ldots \ldots \ldots \ldots \ldots \ldots$

4.2 .1 MIKE 11 geometry . . . . . . . . . . . . . . . . . 20 20

4.2 .2 Boundary conditions . . . . . . . . . . . . . . . . . . 21

4.2 .3 Control structures . . . . . . . . . . . . . . . . . . . 23

4.2 .4 Detention areas . . . . . . . . . . . . . . . . . . 26

4.3 MIKE SHE . . . . . . . . . . . . . . . . . . 30

4.3 .1 Soil . . . . . . . . . . . . . . . . . . . . . . . . . 31

4.3 .2 Vegetation . . . . . . . . . . . . . . . . . . . . 35

4.3 .3 Rainfall . . . . . . . . . . . . . . . . . . . . . . 36

4.3.4 Evapotranspiration . . . . . . . . . . . . . . . . . . . . 37

4.3 .5 Overland flow . . . . . . . . . . . . . . . . . . . . . 38

4.3 .6 Hydrogeology . . . . . . . . . . . . . . . . . . . . . . . 40

4.3 .7 Boundary conditions . . . . . . . . . . . . . . . . . . . 53

4.4 Model Calibration (1987-1997) and Validation (1998-2005) . . . . . 55

4.4 .1 Manning's number . . . . . . . . . . . . . . . . . . . 58

4.4.2 Conductivity of the Surficial Aquifer System . . . . . . . . . . . . 58

4.4 .3 Leakage factor . . . . . . . . . . . . . . . . . . . 58

4.5 Assumptions and Limitations . . . . . . . . . . . . . . . . . 58

5. RESULTS AND DISCUSSION . . . . . . . . . . . . 60

5.1 Exploratory Data Analysis . . . . . . . . . . . . . . . . . . . . . . 61

5.2 Statistical Parameters . . . . . . . . . . . . . . . . . . 63

5.3 Probability of Exceedance . . . . . . . . . . . . . . . . . 65 65

5.4 Water Balance . . . . . . . . . . . . . . . . . . . . . . . . . 69

5.5 Sensitivity Analysis . . . . . . . . . . . . . . . . . . . . 71

5.6 Comparison with Other Models . . . . . . . . . . . . . . . . 74

5.6 .1 Western Marl Prairie . . . . . . . . . . . . . . . . . . . . . 75

5.6 .2 Shark Slough . . . . . . . . . . . . . . . . . . 75 
5.6 .3 Rocky Glades . . . . . . . . . . . . . . . . . . . . 76

5.6 .4 Taylor Slough Basin . . . . . . . . . . . . . . . . . . 77

6. CONCLUSIONS AND RECOMMENDATIONS . . . . . . . . . . . . 79

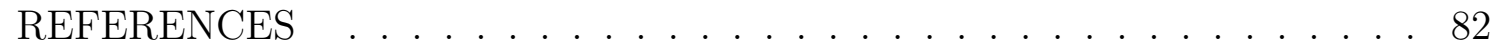




\section{LIST OF TABLES}

TABLE

PAGE

2.1 Approximate range of hydraulic conductivities . . . . . . . . . . . . 9

$4.1 \quad$ Prescribed discharge for L-29 culverts . . . . . . . . . . . . . . . . 22

4.2 Structures used for boundary condition input . . . . . . . . . . . . 24

4.3 Structures used for boundary condition output . . . . . . . . . . . 25

4.4 Structures implemented with operational rules . . . . . . . . . . . 25

4.5 Structures implemented in MIKE 11 as underflow . . . . . . . . . . . . 25

4.6 Hydraulic parameters of soils in the unsaturated zone . . . . . . . . . 33

4.7 Vegetation parameters used for calibration . . . . . . . . . . . . 35

4.8 List of hydrogeologic parameters . . . . . . . . . . . . . . . . . . 42

5.1 Statistical parameters for stations in the vicinity of G3273 . . . . . . . . 64

5.2 Exceedance probability for stations in the vicinity of NE1 . . . . . . . 67

5.3 Comparison of water storage data . . . . . . . . . . . . . 71 


\section{LIST OF FIGURES}

FIGURE

PAGE

2.1 Location of study area . . . . . . . . . . . . . . . . . . 4

2.2 Generalized hydrogeologic framework of aquifer systems . . . . . . . 6

2.3 Surficial aquifer system across central Miami-Dade County . . . . . . . 7

2.4 Conceptual hyrogeologic conditions of the Biscayne Aquifer . . . . . . 8

2.5 STATSGO soil coverage . . . . . . . . . . . . . . . . 11

2.6 Miami-Dade County FL soil map . . . . . . . . . . . . . . . . . . . . . . 12

2.7 FLGAP vegetation coverage . . . . . . . . . . . . . . . . . 13

4.1 Model Domain . . . . . . . . . . . . . . . . . . . . . . . . . . . 19

4.2 MIKE 11 boundary conditions . . . . . . . . . . . . . . 23

4.3 Implementation of canals at the domain boundary . . . . . . . . . . 24

4.4 Configuration of detention areas . . . . . . . . . . . . 27

4.5 Cross sections defining the S357 and C-111 Northern Detention Area . . 28

4.6 MIKE SHE and MIKE 11 exchange . . . . . . . . . . . . . . . 31

4.7 Soil coverage of the study area $\ldots \ldots \ldots \ldots$

4.8 Moisture retention curves . . . . . . . . . . . . . . . . . . 33

4.9 Soil classifications implemented in the model . . . . . . . . . . . . . 34

4.10 Vegetation coverage in the model . . . . . . . . . . . . . . . 36

4.11 Location of USGS wells used to determine hydrogeologic parameters . . 41

4.12 Bottom level of layer 1-Miami Oolite . . . . . . . . . . . . . . . . . 43

4.13 Thickness of layer 1 -Miami Oolite . . . . . . . . . . . . . . . 44

4.14 Horizontal Conductivity of layer 1-Miami Oolite . . . . . . . . . . . 45

4.15 Bottom level of layer 2-Surficial Aquifer System _ . . . . . . . . . 46

4.16 Thickness of layer 1-Surficial Aquifer System . . . . . . . . . . . 47

4.17 Horizontal Conductivity of layer 2-Surficial Aquifer System . . . . . . . 48 
4.18 Location of pump tests used to generate transmissivity of the Surficial

Aquifer System . . . . . . . . . . . . . . . . . . . . . 49

4.19 Transmissivity of layer 1 -Miami Oolite . . . . . . . . . . . . . 50

4.20 Interpolated transmissivity data for Layer 2-Surficial Aquifer System . . 51

4.21 Geological lens representing layer Q5 . . . . . . . . . . . . . 52

4.22 Prescribed subsurface boundary conditions . . . . . . . . . . . . . . 54

4.23 Flow chart of model calibration . . . . . . . . . . . . . . . 56

5.1 Example of stage time series . . . . . . . . . . . . . . 61

5.2 Example of discharge time series . . . . . . . . . . . . . . 62

5.3 Example of accumulated discharge . . . . . . . . . . . . . 62

5.4 Example of stage exceedance probability . . . . . . . . . . . . 65

5.5 Example of exceedance probability for discharge . . . . . . . . . . 66

5.6 Water balance for the model with detention areas . . . . . . . . . . . 70

5.7 Sensitivity for hydraulic conductivity of the Surficial Aquifer System . . 72

5.8 Sensitivity for Manning's number . . . . . . . . . . . . . 73

5.9 Location of stations used for comparison with other models . . . . . . . 74

5.10 Comparison with other models: P34 . . . . . . . . . . . . 75

5.11 Comparison with other models: P33 . . . . . . . . . . . . . 76

5.12 Comparison with other models: NP44 . . . . . . . . . . . . . . 77

5.13 Comparison with other models: NP67 . . . . . . . . . . . 78 


\section{LIST OF ABBREVIATIONS}

$\begin{array}{ll}\text { DA } & \text { Detention Areas } \\ \text { DERM } & \text { Department of Environmental Resources Management } \\ \text { ENP } & \text { Everglades National Park } \\ \text { ET } & \text { Evapotranspiration } \\ \text { ICU } & \text { Intermediate Confining Unit } \\ \text { Kc } & \text { Crop coefficient } \\ \text { LAI } & \text { Leaf Area Index } \\ \text { Manning's M } & \text { M }=(1 / \text { n): the reciprocal of Manning's n } \\ \text { MDCSM } & \text { Miami Dade County Soil Map } \\ \text { NDA } & \text { No Detention Areas } \\ \text { NPS } & \text { National Park Service } \\ \text { NRCS } & \text { U.S. Department of Agriculture Natural Resource Center } \\ \text { Qm } & \text { Miami Oolite } \\ \text { RD } & \text { Root Depth } \\ \text { SAS } & \text { Surficial Aquifer System } \\ \text { SFWMD } & \text { South Florida Water Management District (the District) } \\ \text { SFWMM } & \text { South Florida Water Management Model } \\ \text { SSURGO } & \text { Soil Survey Geographic Database } \\ \text { STATSGO } & \text { State Soil Geographic Database } \\ \text { SZ } & \text { Saturated Zone } \\ \text { TIME } & \text { Tide and Inflows in the Mangroves of the Everglades } \\ \text { USACOE } & \text { U.S. Army Corps of Engineers (the Corps) } \\ \text { USGS } & \text { U.S. Geological Survey } \\ \text { UZ } & \text { Unsaturated Zone }\end{array}$




\section{CHAPTER 1 \\ INTRODUCTION}

The Everglades is the largest sub-tropical ecosystem in the United States and home to numerous unique and endangered plant and animal species. The original Everglades was a shallow wetland, where water flowed freely from Lake Okeechobee in central Florida, south through the Mangrove estuaries and Florida Bay. Beginning in the 1880s, water control structures and canals were constructed to provide land for human settlement and agriculture. These projects not only reduced the Florida Everglades by more than half, but they also created a water deficit in the dry seasons and an over abundance of water in the wet season [1]. Established in 1947 by President Harry S. Truman, the Everglades National Park (ENP or the Park) serves to prevent further destruction of the remaining Everglades system. Water management projects in the area serve to return the natural flow regime to the remaining native wetland areas in an attempt to preserve and restore the diverse and unique flora and fauna that is found only in this area [2]. Since the Flood Control Act of 1968, federal and state agencies have been working to balance flood control for the established urban and agricultural areas with protecting of what remains of the Everglades [1]. However, only 25 percent of the original freshwater ecosystem remains within ENP [3].

There are numerous uncertainties concerning water delivery and control techniques and how they influence the interaction of the groundwater and surface water systems. The interaction of groundwater and surface water systems affect the flow, water levels, and destination of rerouted water within South Florida. While previously developed models, such as the South Florida Water Management Model (SFWMM) [4] and the Tides and Inflows in the Mangroves of the Everglades (TIME) [5], have been used for studying critical aspects of the hydrology in ENP, 
there is a research gap for the detailed hydrology needed in the areas of Shark Slough, the tree islands of the Western Marl Prairie, and the eastern boundary of the Park. The tree islands and Shark Slough are where the endangered Cape Sable Seaside Sparrow nest [2]. The nesting habitats of the sparrows are extremely sensitive to the timing of changing water levels, which are now controlled by water management operations schedules. The sensitive species will become extinct if water management projects deliver too much water to these areas during their nesting season. The complexity and diversity of the Everglades National Park's hydrology and the sensitivity of species in the Park require a comprehensive and detailed study of the flow regime and inclusion of the full hydrological cycle.

The models selected for the study are the MIKE SHE and MIKE 11 models, developed by the Danish Hydrological Institute (DHI). The coupled model is expected to be applied as analytical tool to determine the effects of proposed restoration projects, water management scenarios, and structure operation schedules on the current hydrology within the Park. The goal of this research is to develop a sophisticated hydrological model, which couples the surface and groundwater within the Park watershed, that will lead to a better understanding of the groundwatersurface water interaction and provide a tool to properly evaluate hydrology within the Park and make appropriate recommendations for future water control and delivery projects. 


\section{CHAPTER 2}

\section{BACKGROUND OF THE STUDY AREA}

Everglades National Park makes up approximately 2,400 square miles of South Florida. The study area, shown in Figure 2.1, includes 1,050 square miles of South Florida. Model development for this thesis is concentrated on the fresh water flow into Shark River Slough, Rocky Glades, most of the Western Marl Prairie, and the majority of Taylor Slough. The study area was chosen to exclude sections of brackish and salt water, as well as the river system in the western portion of the Park where data is scarce and less reliable.

The area includes more than 110 miles of levees and canals, along with their associated gates, weirs, pumps, culverts, and water storage areas. Control structures in the area are operated based on the operation schedules of the South Florida Water Management District (SFWMD or the District) [6] or the US Army Corps of Engineers (USACOE or the Corps) [7]. More than 300 monitoring stations are located within the study area which record groundwater levels, canal discharges, precipitation, and/or water levels. Daily time series of recorded data are available from the District, United States Geological Survey (USGS), and National Park Service (NPS).

\subsection{Hydrogeology}

A generalized vertical transect of the hydrogeology of Miami-Dade County was reported by Fish and Stewart [9]. Two major aquifer systems were identified: the Floridan aquifer and an intermediate confining unit (ICU). The Floridan aquifer system is approximately 950 to $1,000 \mathrm{ft}$ below sea level. The ICU overlays the Floridan aquifer system and has a thickness of 550 to $800 \mathrm{ft}$. The ICU consists of

green clay, silt, limestone, and fine sand. There are a few zones with possibly minor 


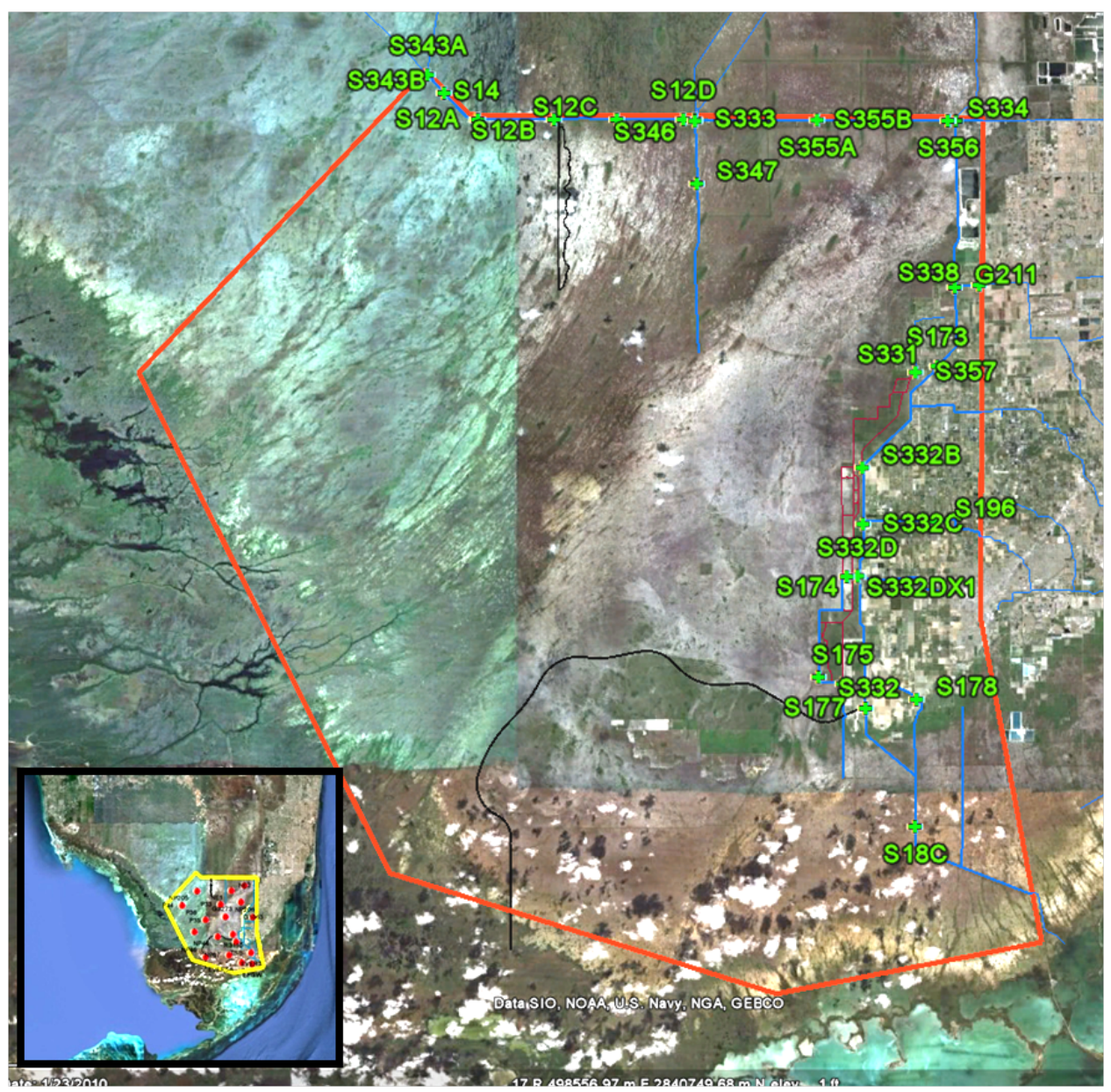

Figure 2.1: Location of study area (outlined in red), control structures (green crosses), canal network (blue lines), and ENP roads (black lines). Satellite image courtesy of Google Earth [8]

aquifers, but in general, the sediments have relatively low permeability. Most of this sequence is included in the Miocene Hawthorn Formation, but the upper most sediments of the sequence may locally be part of the Miocene-Pliocene Tamiami Formation.

The surficial aquifer system (SAS) overlays the ICU. The ICU and the SAS are suggested to be present for the majority of South Florida and presumably ENP [12]. The heads in the confined Floridan aquifer system are considerably above water- 
table elevations, while the hydraulic heads throughout the SAS are at or close to water-table elevations, which is generally less than $10 \mathrm{ft}$ above sea level.

The SAS comprises all the rocks and sediments from land surface downward to the top of the ICU. The top of the system is land surface, and the base of the system is defined hydraulically by a several orders of magnitude change in average permeability. The SAS consists primarily of limestones and sandstones, sand, shell, and clayey sand with minor clay or silt. The upper part of the ICU is usually green clay or silt, and locally sandy, except near the northeastern coastal Miami-Dade County and coastal Broward County where there is green, fine-grained calcarenite. Regionally, this green clay or silt is usually present at the top of the Hawthorn Formation.

Major layers of the SAS reported by Fish and Stewart [9] include the Biscayne Aquifer and the Gray Limestone Aquifer. From the land surface downward, the Biscayne aquifer is composed of Pamlico Sand, Miami Oolite, Anastasia Formation, Key Largo Limestone, and Fort Thompson Formation (all of Pleistocene age), and contiguous, highly permeable beds of the Tamiami Formation (Pliocene and late Miocene age). A generalized hydrogeological framework for the aquifer system within Miami-Dade County proposed by Fish and Stewart is shown in Figure 2.2.

The Biscayne aquifer boundary is presumed to be where the Fort Thompson Formation, Anastasia Formation, or Key Largo Limestone grade laterally into lesspermeable facies. At least $10 \mathrm{ft}$ of the Biscayne aquifer has a horizontal hydraulic conductivity of about 1,000 ft/day or more [9]. Miami-Dade and Broward Counties' sandstones and limestones have a well-developed secondary porosity with hydraulic conductivities commonly exceeding 10,000 ft/day [9]. Silt, clay, and mixtures of lime mud, shell, and sand in the upper and lower clastic units of the Tamiami Formation 


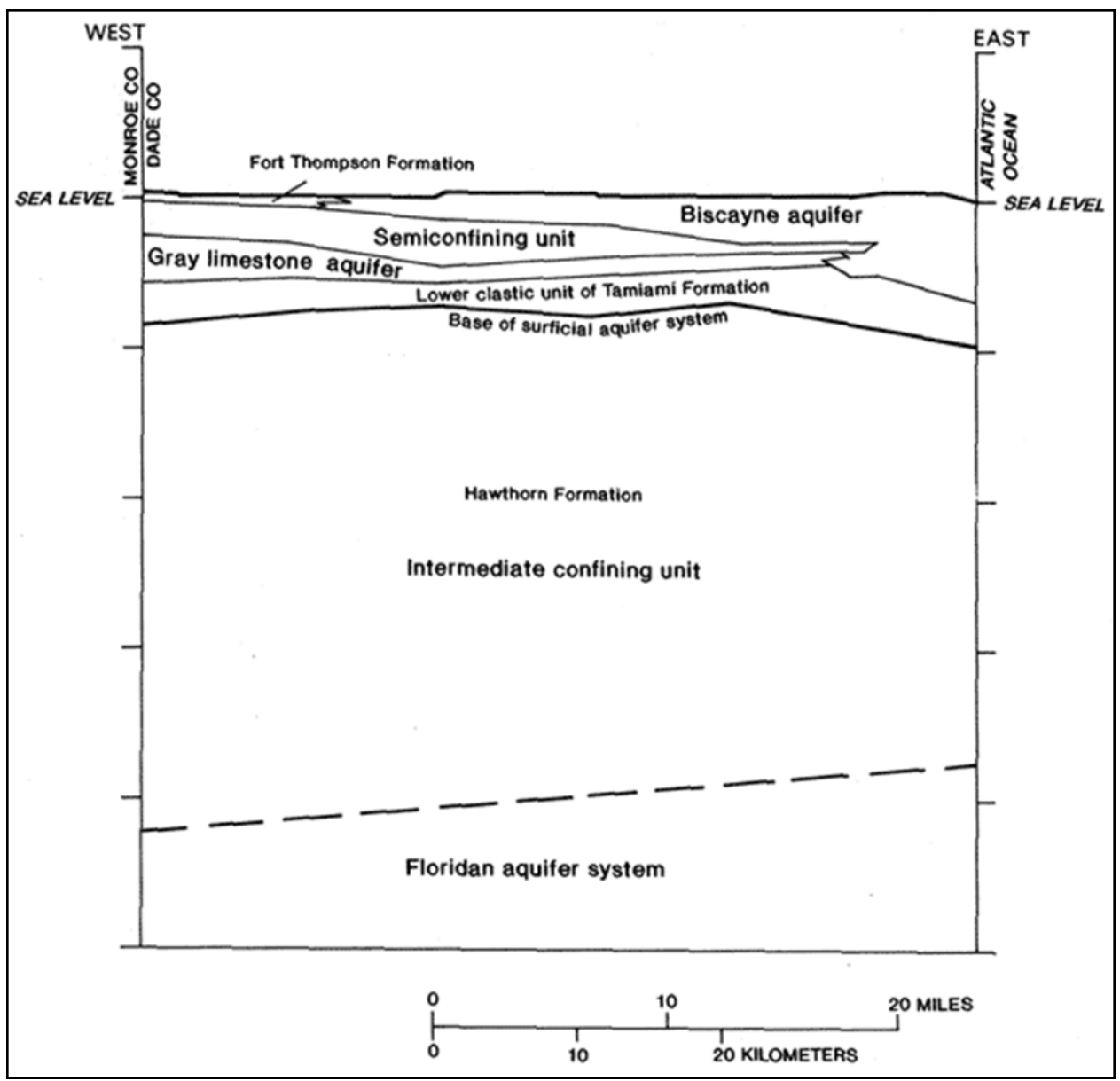

Figure 2.2: Generalized hydrogeologic framework of aquifer systems in Miami-Dade County [9]

have hydraulic conductivities of 0.001 to $1 \mathrm{ft} /$ day [9]. Some dense limestones within the SAS also have relatively low hydraulic conductivities.

The gray limestone aquifers have high permeabilities and, as mapped by Fish and Stewart, have a minimum hydraulic conductivity of $100 \mathrm{ft} /$ day [9]. Fish and Stewart also estimated that there are highly permeable sand and sandstone beds above or below, and connected laterally to the limestone. Permeable units (aquifers or smaller sections with higher permeability within aquifers) can exhibit semi-confined characteristics when stressed due to large permeability contrasts with adjacent sediments. 


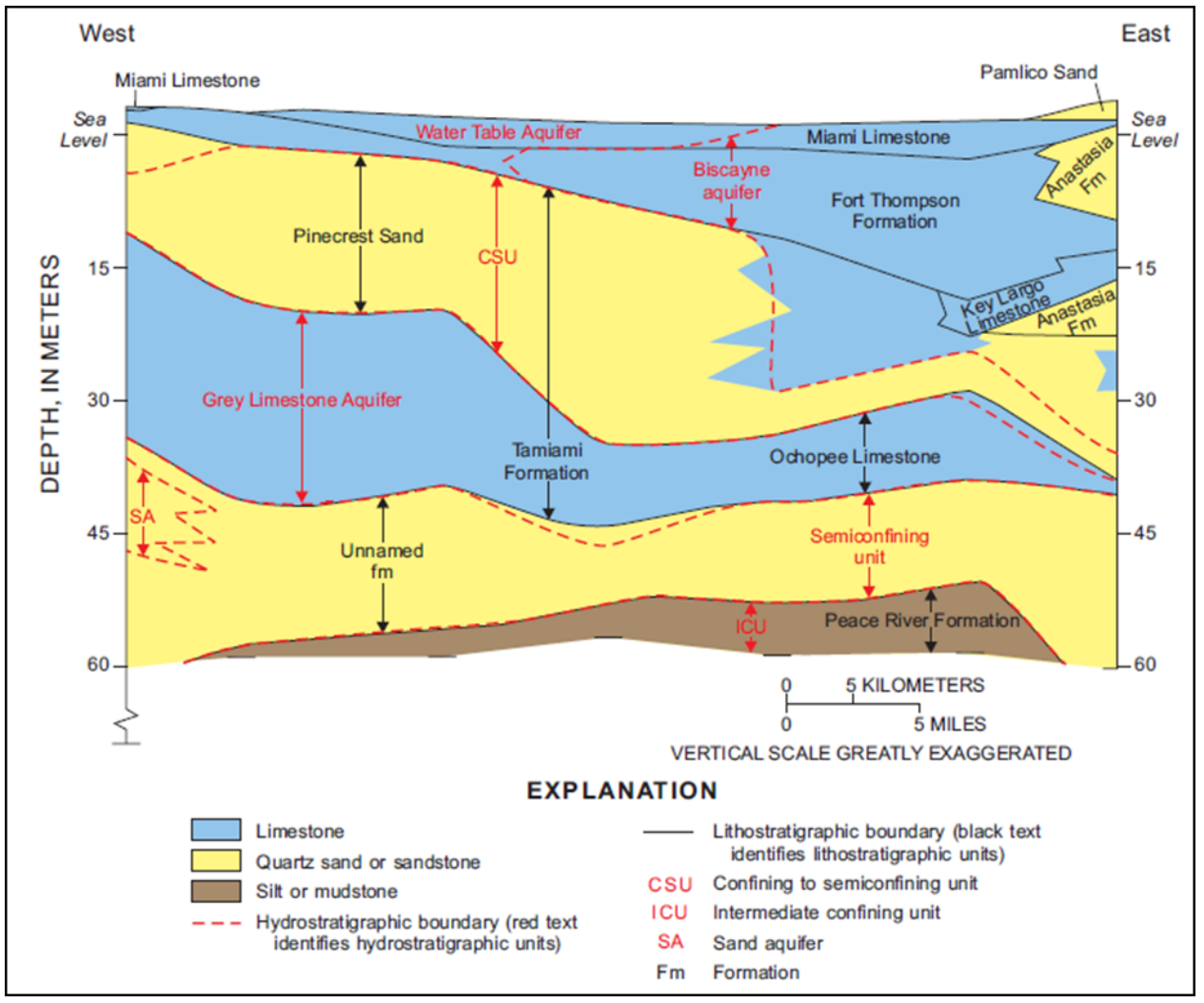

Figure 2.3: Surficial aquifer system across central Miami-Dade County. Geologic formations, aquifers, and semipermeable units of the SAS across central MiamiDade County [10]

Figure 2.3, from Reese and Cunningham [10], provides the generalized composition of the SAS along Tamiami Trail.

Hydrogeologic test drilling transects across South Florida identified a number of geologic formations and units [9]. The drilling transects where located across Miami-Dade County and a large section of the ENP. The hydrologic properties of the geologic formations are listed in Table 2.1. Transmissivity values exceeding $300,000 \mathrm{ft}^{2} \mathrm{day}^{-1}$ were reported in nearly all of central and eastern Miami-Dade County with an abrupt decrease to less than $75,000 \mathrm{ft}^{2} \mathrm{~d}^{-1}$ in western Miami-Dade County [9]. The decrease in transmissivity coincides with the western boundary of the Biscayne aquifer. The areas of very high transmissivity are associated with the 
limestones and calcareous sandstones of the Biscayne aquifer, principally within the Fort Thompson Formation. Transmissivity of the gray limestone aquifer in western Miami-Dade County ranges from about 5,800 to 39,000 $\mathrm{ft}^{2} \mathrm{day}^{-1}$ [9].

Nemeth et al [11] used 6 layers to develop a conceptual model of the subsurface hydrology in the vicinity of Levee-31N, north of station G-211, in Miami-Dade County. The hydraulic conductivity was estimated to be $29,000 \mathrm{ft} /$ day in the Biscayne aquifer and $470 \mathrm{ft} /$ day in the Tamiami Formation below the aquifer. There are two semi-confining layers of low-permeability limestone in the study area. The shallower semi-confining layer is about $2 \mathrm{ft}$ thick and is located at the top of the Fort Thompson Formation, just below the Miami Limestone. The deeper semi-confining layer averages about $5 \mathrm{ft}$ thick and has nearly the same slope as the upper surface of the Tamiami Formation. The layers used for the conceptual model are shown in Figure 2.4.

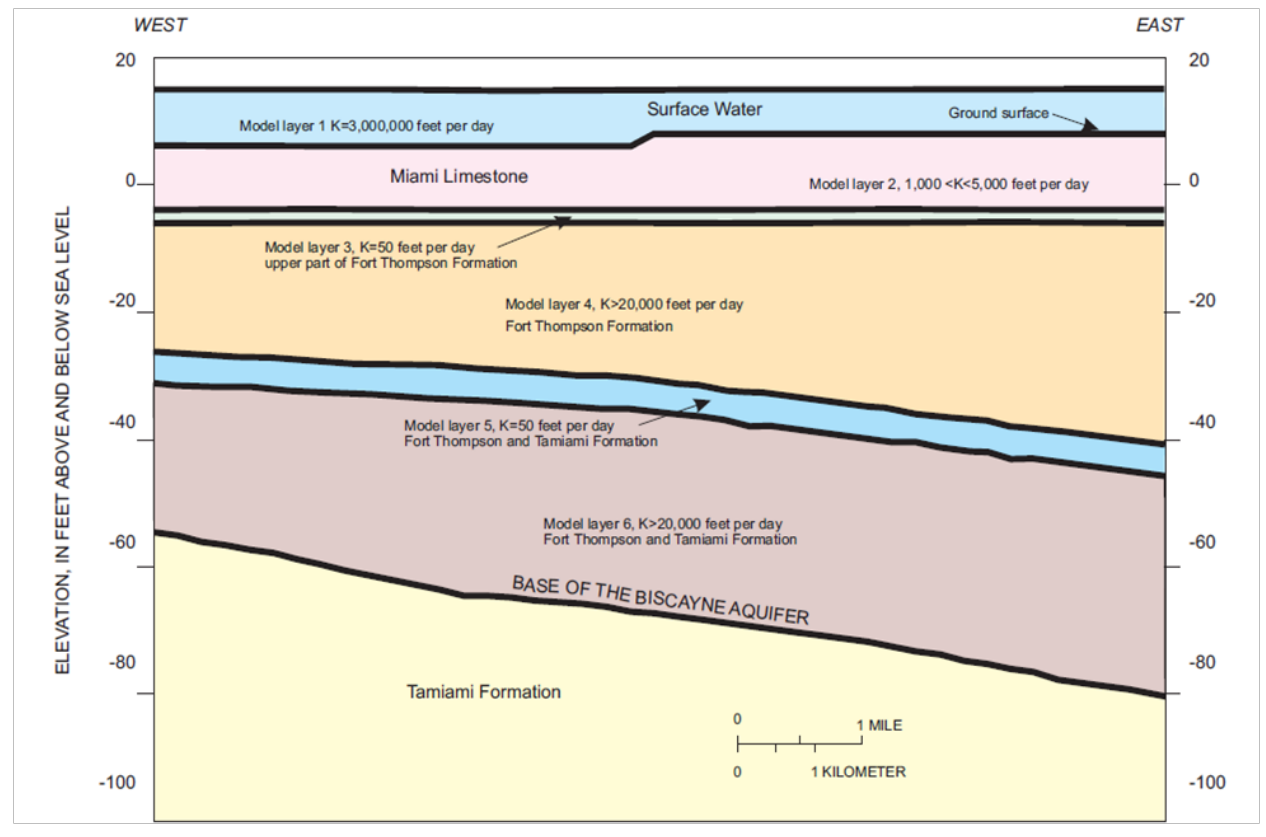

Figure 2.4: Conceptual hyrogeologic conditions of the Biscayne Aquifer, domain is north of structure G-211 [11] 
Table 2.1: Approximate range of hydraulic conductivities for Miami-Dade County [9]

\begin{tabular}{|c|c|c|}
\hline Range & Sediments-lithology and porosity & Geologic formation \\
\hline \multirow[t]{4}{*}{$\begin{array}{l}\text { Very high } \\
(\geq 1,000)\end{array}$} & $\begin{array}{l}\text { Solution-riddled limestone, commonly shelly or sandy. } \\
\text { Calcareous sandstone, may be shelly or have shell frag- } \\
\text { ments. }\end{array}$ & Qf, Qa \\
\hline & Solution holes or riblike channels. & $\mathrm{Qa}, \mathrm{Tt}$ \\
\hline & Coralline limestone, reefal, very porous. & Qk \\
\hline & Oolitic limestone. & Qm \\
\hline \multirow{5}{*}{$\begin{array}{l}\text { High } \\
(100-1,000)\end{array}$} & Gray, shelly limestone, locally sandy, relatively soft. & $\mathrm{Tt}$ \\
\hline & $\begin{array}{l}\text { Limestone or calcareous sandstone interbedded with sand } \\
\text { or with sand partially filling cavities. }\end{array}$ & $\mathrm{Qa}, \mathrm{Tt}, \mathrm{Qf}$ \\
\hline & Coarse shell sand and quartz sand. & $\mathrm{Tt}$ \\
\hline & $\begin{array}{l}\text { Dense, charcoal gray to tan limestone with some solution } \\
\text { channels, usually shelly or sandy }\end{array}$ & Ttu \\
\hline & Oolitic limestone. & Qm \\
\hline \multirow{7}{*}{$\begin{array}{l}\text { Moderate } \\
(10-100)\end{array}$} & Very fine to medium, relatively clean, quartz sand. & $\mathrm{Qp}, \mathrm{Qa}, \mathrm{Tt}$ \\
\hline & Fine to medium quartz and carbonate sand. & $\mathrm{Tt}$ \\
\hline & Cream-colored limestone with minor channels. & Qf, Qa \\
\hline & $\begin{array}{l}\text { Tan, cream, or greenish limestone, locally containing shelly } \\
\text { sand. }\end{array}$ & $\mathrm{Tt}$ \\
\hline & Calcareous sandstone and sand. & $\mathrm{Tt}, \mathrm{Qa}$ \\
\hline & Slightly clayey or sandy, gray limestone. & $\mathrm{Tt}$ \\
\hline & $\begin{array}{l}\text { Light-green, foraminiferal limestone, locally sandy or } \\
\text { shelly. }\end{array}$ & $\mathrm{Th}$ \\
\hline \multirow[t]{5}{*}{ Low $(0.1-10)$} & $\begin{array}{l}\text { Very fine to medium sand with some clay, silt, or lime mud; } \\
\text { locally shelly. }\end{array}$ & Tt, Qf, Qa \\
\hline & Soft gray or buff limestone with silt and fine sand. & $\mathrm{Tt}$ \\
\hline & Dense, calcareous sandstone. & $\mathrm{Tt}$ \\
\hline & $\begin{array}{l}\text { Light-green, fine-grained foraminiferal limestone with very } \\
\text { fine quartz sand. }\end{array}$ & $\mathrm{Tt}$ \\
\hline & $\begin{array}{l}\text { Dense, hard limestone with very small cavities or channels. } \\
\text { Approximately equal mixtures of sand, shell fragments, and } \\
\text { lime mud. }\end{array}$ & Qf \\
\hline \multirow{4}{*}{$\begin{array}{l}\text { Very low to prac- } \\
\text { tically } \\
\text { impermeable } \\
(\leq 0.1)\end{array}$} & $\begin{array}{l}\text { Green clay or silt; locally with very fine sand: siltstone, } \\
\text { claystone, often sandy. }\end{array}$ & Tth, Ttl, Ttu \\
\hline & Sandy, shelly lime mud. & $\mathrm{Tt}$ \\
\hline & $\begin{array}{l}\text { Very dense, hard limestone with no apparent solution cav- } \\
\text { ities or fractures. }\end{array}$ & Qf \\
\hline & $\begin{array}{l}\text { Dense, hard oolitic limestone with no apparent solution } \\
\text { cavities or fractures. }\end{array}$ & Qm \\
\hline
\end{tabular}




\section{$2.2 \quad$ Soil}

The soils within ENP range from sand to nutrient rich peat. Numerous sources of soil coverage are available for the Everglades, including the United States Department of Agriculture Natural Resources Conservation Service (NRCS) Soil Survey Geographic Database (SSURGO) [12] and State Soil Geographic Database (STATSGO) [13] and USGS Miami-Dade County FL Soil Map [14].

SSURGO is the most detailed soil mapping coverage with over 18,000 soil series for the United States [12]. SSURGO is very detailed, but only has data for the eastern portion of the study area. The NRCS dramatically generalized SSURGO to create STATSGO which provides soil mapping for the entire state of Florida and includes coverage for over the entire study area. For the areas lacking coverage by SSURGO, STATSGO statistically expanded the coverage using geology, topography, vegetation, and remote sensing. Soils with similar characteristics are grouped together to create the polygons as seen in Figure 2.5.

The Miami-Dade County FL soil map (MDCSM) is derived from twelve individual soil maps included in the U.S. Department of Agriculture Soil Survey Detailed Reconnaissance, April 1958. The individual maps were scanned and digitized for GIS analysis. The GIS files were updated by the USGS in 2001 with more than 49 soil types. The MDCSM was revised again by Jones in 2006 [15]. Figure 4.9 shows the 2006 updated soil coverage. The predominant soils reported are sandy marl, everglades peat, and perrine marl. Additional details about the soil data collection including relevant attributes for each soil type are provided on the USGS web site. 


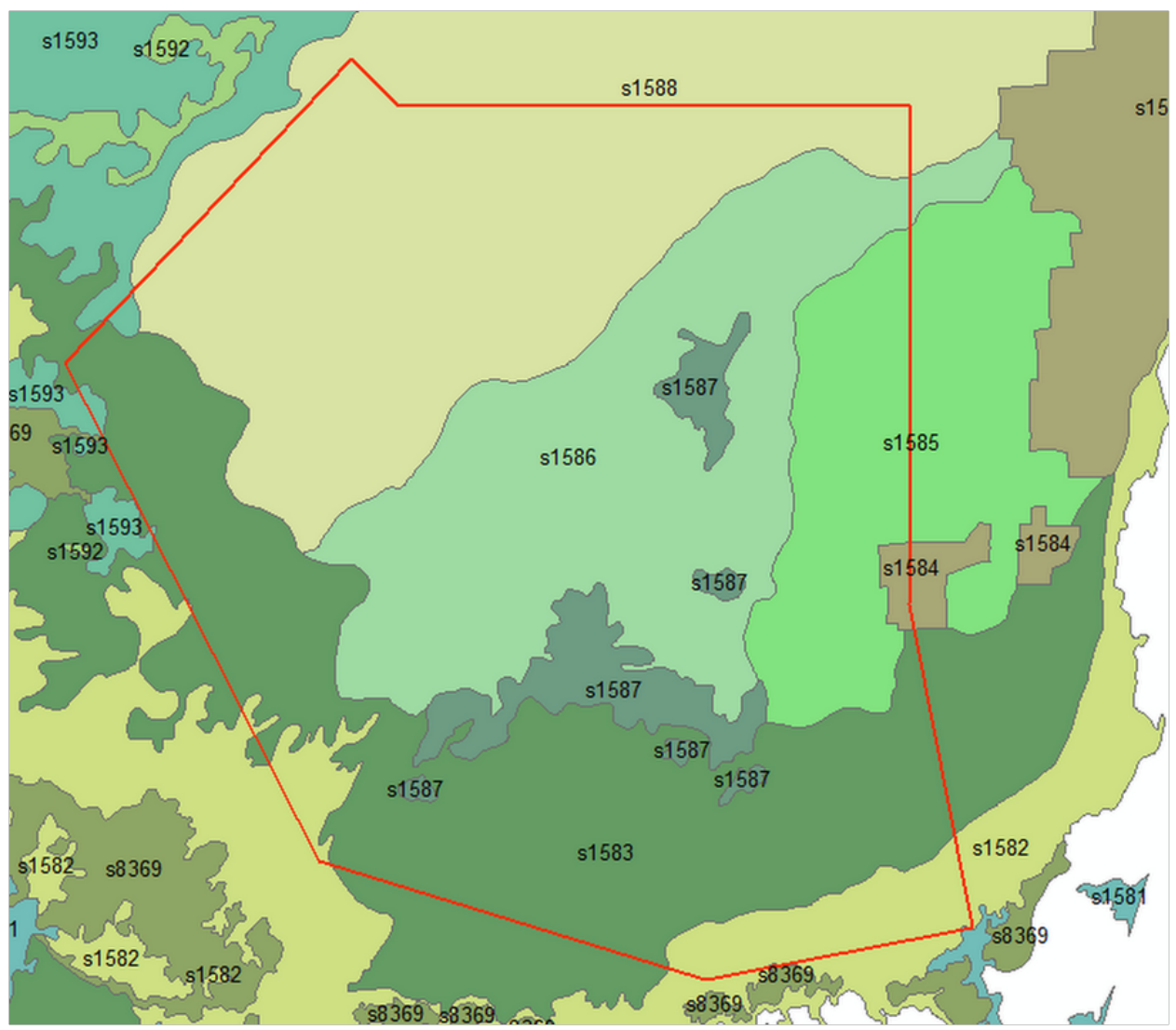

Figure 2.5: STATSGO polygon coverage of the study area. Soil types are: s1582 Terra Ceia-Perrine-Pennsuco-Okeelanta, s1583 Perrine-Pennsuco-Biscayne, s1586 Rock Outcrop-Chekika-Biscayne, s1588 Pahokee-Luderhill-Dania, and s1593 Riviera-Copeland-Boca [13] 

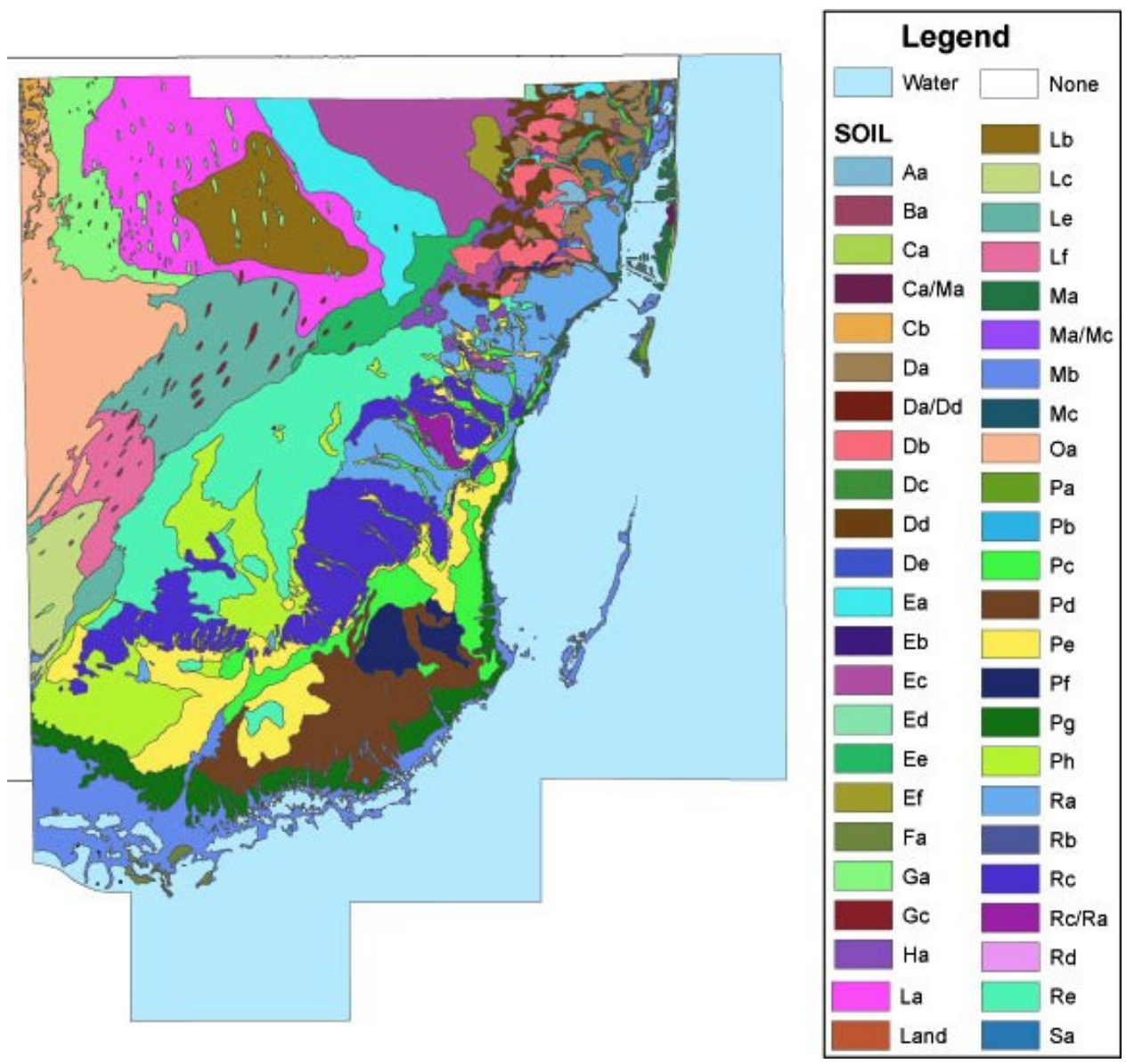

Figure 2.6: Miami-Dade County FL Soil Map. Definitions for the legend can be found at http://sofia.usgs.gov/exchange/jjones/jjones.html [14] 


\subsection{Vegetation}

The Everglades is characterized by having a unique, diverse vegetation. The Florida Gap Project (FLGAP) [16], sponsored by the USGS Biological Resources Division, is based on the United States National Vegetation Classification System and the Florida GAP classification. FLGAP provides a greater level of detail in comparison to the vegatation coverage provided by the National Land Cover Database 2001 data from USGS [17]. FLGAP includes more than 70 categories of vegetation along with the associated leaf area index (LAI) and root depth (RD) time series. Figure 2.7 shows the FLGAP vegetation coverage within the study area. The main categories reported in the study area include the Freshwater Marsh/Wet Prairie and Wet Shrubland.

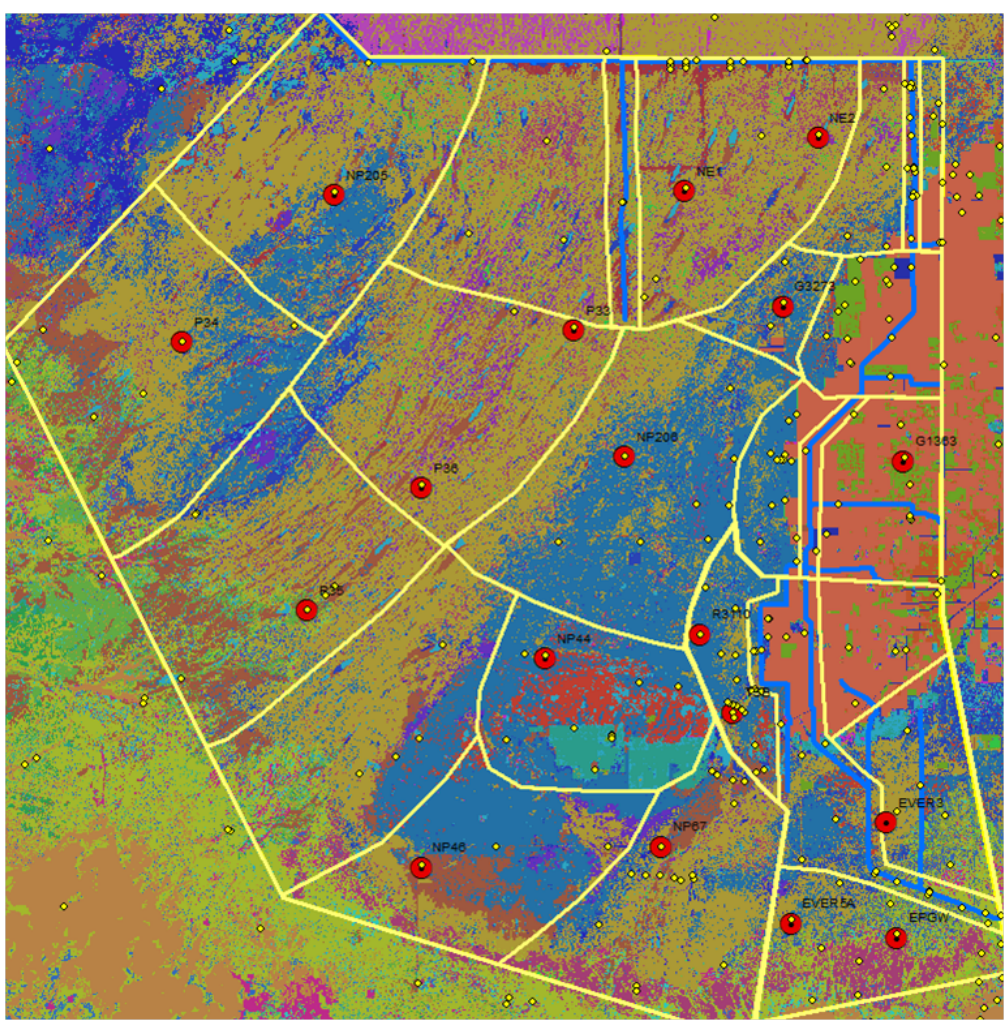

Figure 2.7: FLGAP vegetation coverage [16] 


\section{CHAPTER 3 RESEARCH JUSTIFICATION AND OBJECTIVES}

Computer models were developed in the past to study restoration of the historic, natural hydrology of the Everglades ecosystem [18], to determine effects of water management structures and their operations on the current hydrology of the Park $[19,20]$, or how alterations to hydrology would affect species in the area [21]. Most of these models have a restricted domain, include a small portion of the remaining natural Everglades system, or study a limited portion of the hydrologic cycle without the details necessary to make informed decisions for water management operations and restoration strategies. Models, which cover the study area, include South Florida Water Management Model [4] and the Tides and Inflows in the Mangroves of the Everglades [5]. The proposed research will address many limitations of previously developed models and will target accurate stage (errors less than $0.2 \mathrm{ft}$ ) and flow calculations, implement control structures, and take into account canal seepage rates. Due to the increased complexity of water control, operation schedules, and management structures, improved models are required to reduce the uncertainty of the restoration scenarios. This can be achieved by incorporating a greater number of the components impacting the hydrological system.

The main research objective of the study is to develop a modeling tool with an enhanced predictive capability compared to other tools currently available, to simulate the flow regimes of ENP. This objective will be achieved by implementing an increased spatial resolution, a better defined surface-subsurface interaction, a more accurate physical description of ENP, and operation schedules. 
A number of specific objectives attempted to answer the following questions:

- According to the regional water balance, what components have the greatest influence on the regional hydrology?

- What are the subsurface flow components?

- What is the water distribution between the surface and subsurface layers?

- What is the current flow path of water through the Park according to current daily hydrological events, such as rainfall and ET, and current vegetation patterns?

The proposed model will provide a more accurate account of operation schedules and infiltration rates, use a finer grid resolution, implement control structures, such as culverts, levees, and pumps, include a defined canal package, and shorten model run times and computations by simplifying the subsurface system. In addition, a considerable advantage of the proposed MIKE SHE/MIKE 11 model is the use of the Saint Venant equation for free surface flow. Previously developed models have used Darcy's law with a very high conductivity value. Darcy's law is defined for flow through porous medium. Increasing the conductivity in Darcy's law makes an approximation of the free surface flow, however, the Saint Venant equation is a more accurate method and accounts for backwater conditions which occur in the study area.

\subsection{Other Models of the Study Area}

South Florida Water Management Model: The SFWMD began developing the SFWMM, a regional scale model, in the 1970s. The domain is comprised of a $2 \times 2$ mile grid and covers 7,600 square miles of South Florida from Lake Okeechobee to 
Florida Bay [4]. The model includes significant hydrological parameters and aims to simulate hydrology and water management scenarios. This model is widely applied in planning water management and operation schedules in South Florida. However, the model output is averaged over an area of 4 square miles and lacks the details needed for stage variations of the isolated wetlands found in the Everglades. In addition, since the computational power is consumed by operations of hundreds of control structures, the model is limited to water depth and general flow calculations [18]. The SFWMM is more suited to be used as an input for other more detailed hydrological models [22], than to analyze the hydrology within ENP.

Tides and Inflows in the Mangroves of the Everglades: The TIME project began in 1999 as a collaborative effort between USGS, NPS, and South Florida Natural Resource Center (SFNRC) [23]. The model uses the FTLOADDS (Flow and Transport in a Linked Overland/Aquifer Density Dependent System) code which couples SWIFT2D, a two-dimensional surface water and transport model, with SEAWAT, a three-dimensional groundwater and transport model with variable density [5]. The model has a $500 \mathrm{~m}$ grid resolution. with boundaries along Tamiami Trail to Everglades City in the north, L-31N and C-111 canals in the east, Florida bay in the south, and the Gulf of Mexico in the West. TIME aims to simulate salinity fluxes along the coastal estuaries and fresh water inflows within the Park [23]. As the name suggests, the model focuses on the effects of wetland sheet flow and tidal fluctuations on the Mangrove ecosystem, but the model is also being applied to predict hydroperiods throughout the Park. SFWMM simulation results are used as boundary conditions for the surface water inflows and groundwater stages for the North and East boundaries. The use of SFWMM $2 \times 2$ mile grid input causes some errors in calculating stages when used for input in the $500 \mathrm{~m}$ TIME grid cells. There is also concerns with the infiltration within the TIME model, as some rainfall 
in the simulations does not infiltrate properly which prevents analysis of surface water hydroperiods. The implementation of infiltration in the model has not been verified [23].

The TIME model includes 10 subsurface layers. The topography is defined by a variable thickness in the first layer which has a bottom depth positioned at -7 m NGVD88. The elevation of the top surface layer also defines a "preferred flow path" for the overland flow because there is not a module in the model for defining canals [23]. With no module for defining canals, they are defined by boundary conditions. The lack of such a module limits the ability to accurately define water flow and velocities, may lead to water balance errors, and does not allow for an accurate representation of the Park hydrology. The width of rivers in the model are defined by the width of cells. For the TIME model 2.0, the smallest river width is $500 \mathrm{~m}$ [23]. This limitation can have profound implications when describing the variable landscape of the tree islands. 


\section{CHAPTER 4 \\ METHODOLOGY}

The steps of model development consisted of:

- Development of MIKE 11 flow model for canals and water management components, such as control structures, culverts, cross sections, gates and pumps

- Development of MIKE SHE overland and subsurface flow model

- Coupling of the canal (MIKE 11) and subsurface (MIKE SHE)

- Model calibration for the selected historical period $(1 / 1 / 87-12 / 31 / 1997)$

- Analysis of model performance by comparing computed time series to observed time series, using statistical analysis for observed and computed data pairs

- Model verification for the selected time period (1/1/98-12/31/05)

- Implementation of detention areas along L-31N and C-111

- Comparison of the computed water levels at five monitoring stations in the study area with the SFWMM and TIME 2.0 model simulation results

\subsection{Model Domain and Discretization}

The model domain includes an area of approximately 1,050 square miles, 110 miles of canals, Main Park Road, Shark Valley Loop Road, C-111 detention areas, monitoring stations, and control structures along the canals, including the culverts along Tamiami Trail. Figure 4.1 shows the model domain. The north boundary of the model domain is at L-29 from S343A to east of L-30 and S336. The domain includes the northeast portion of Park and the urban settlements between the Park's eastern boundary and Krome Avenue. The western and southern boundaries were selected to exclude the tidal zones and riverine estuaries where data is scarce. 
Topography contour lines were provided by NPS. LIDAR and NEXRAD data were used, along with local Topo survey data for the 8.5-mile area, to manually draw the contour lines with a 50-mile interpolation which were then extrapolated to $400 \mathrm{~m}$ for model implementation.

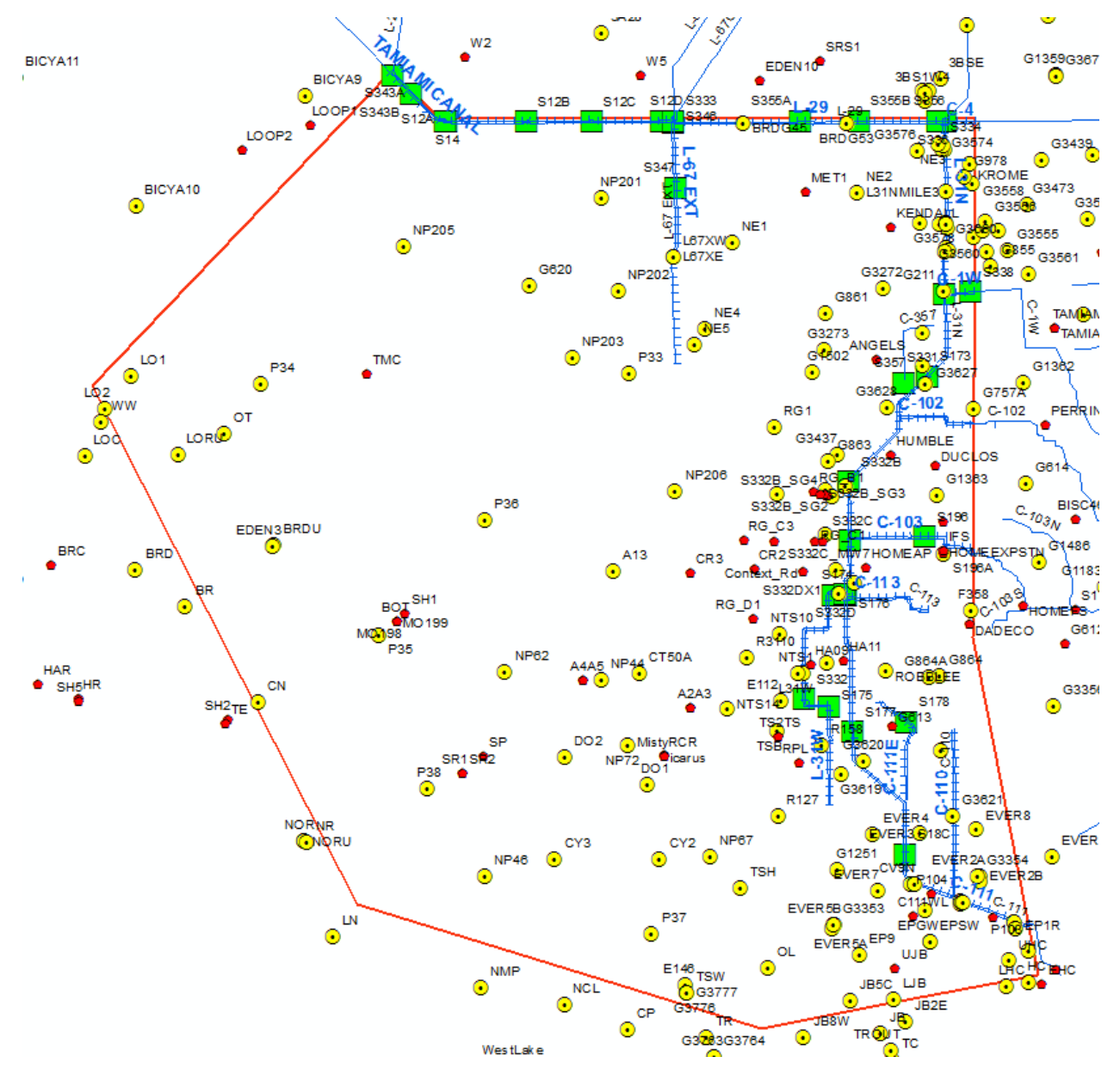

Figure 4.1: Model domain (outlined in red), monitoring stations (yellow dots and red circles), canals and cross sections (light blue), and structures (green squares)

The model grid resolution was varied between 100, 200, 400, and $600 \mathrm{~m}$. The majority of the model computation time was expended on the overland flow module due to the low gradient sheet flow across ENP. A resolution of $400 \mathrm{~m}$ was selected for the model development based on model run times and desired resolution. 


\subsection{MIKE 11}

The MIKE 11 component is a one-dimensional dynamic flow model for rivers, channels, irrigation systems, and canals and includes structure operations and schedules. MIKE 11 analyzes the management and operation of canals and rivers. The complete Saint Venant equation is solved between all grid points at a specified time step for the given boundary conditions. The hydrodynamic module of MIKE 11 contains an implicit finite difference computation of unsteady flows in rivers and canals. Both sub-critical and supercritical flows are described by a numerical scheme which adapts according to local flow conditions. In addition, the model includes options for diffusive wave, kinematic wave, quasi-steady state, kinematic routing, and high order, fully dynamic flow descriptions [24].

\subsubsection{MIKE 11 geometry}

The initial MIKE 11 model for the calibration period of 1987 to 1997 implements the primary canal network and pertinent water management structures which were operational for the selected time period. Control structures along the canals which historically modified the water flux through the north and east limits of ENP were implemented in the model, including the full historical L-67 EXT length of 9.8 miles.

The model for the canal network was implemented using polyline GIS maps obtained from SFWMD's GIS Data Catalog. MIKE 11 requires canal cross sections between canal junctions, before and after control structures, and where changes in canal bed slope, cross section area, canal resistance, or leakage factors occur. AS BUILT surveys provided by the SFWMD Map Room, as scanned drawings in DVD format, were used to determine canal cross sections and profiles. Cross sections for most canals east of L-31N and C-111 were extracted from AUTOCAD 
files obtained from DERM. For areas not covered by the DERM files, the distance between canal berms was determined manually using high resolution aerials and the ARC MAP distance measurement tool. A canal slope, $\mathrm{H}: \mathrm{V}$, of 1:2 was assumed. Smooth transitions along the canal bottom were maintained when generating cross sections and a uniform Manning's number $\mathrm{M}$ was used to define the bed resistance. Manning's number M, is the reciprocal of the commonly used Manning's n, of 30 $\mathrm{m}^{1 / 3} \mathrm{~s}^{-1}$.

\subsubsection{Boundary conditions}

MIKE 11 boundary conditions, shown in Figure 4.2, include prescribed inflows, outflows, and water levels for the canals crossing the model domain. Structures S338, S194, S196, and S197 specify discharge outside the model domain. The observed water level at BRDG105, located approximately 10 miles west of the domain boundary, provides the boundary condition at the west end of L-29. In addition, S343A is implemented as a closed discharge boundary so discharge becomes overland flow. Discharges through the culverts along L-29 are defined as percentage of the total flow in L-30 to station FMB. Table 4.1 lists the percentages provided by NPS [25]. The percentage's ensure the correct discharge from WCA3 enters the model domain. A link just north of S12A used S12A headwater as the boundary condition for east L-29 and S12A. Figure 4.3 shows the approach for modeling the canals along the domain boundary in MIKE 11.

Boundary $Q_{L-30}$ - A discharge time series is used for the inflow discharge into L-31N. The discharge is calculated using the sum of discharges through S334 and S335 and a seepage of $25 \mathrm{cfs}$ of (based on $20 \mathrm{cfs} / \mathrm{mi} / \mathrm{ft}$-head) received from the water conservation area (for 1.25 miles canal length). 
Boundary $Q_{C-1 W}$ - The prescribed boundary condition is the daily time series of flow through structure S338.

Boundary $Q_{C-102}$ - The outflow from the domain through S194.

Boundary $Q_{C-103}$ - The discharge boundary condition through structure S196 on C-103 allows for inflow discharges to the model domain.

Boundary $Q_{C-111}$ - The outflow discharge through structure S197.

Table 4.1: Prescribed discharge for L-29 culverts [25]

\begin{tabular}{|c|c|}
\hline Culvert & Percent Flow \\
\hline 24 & $5.46 \%$ \\
25 & $4.46 \%$ \\
26 & $3.15 \%$ \\
27 & $3.19 \%$ \\
28 & $1.08 \%$ \\
\hline \multicolumn{2}{|c|}{ From flow at L-30 to FMB } \\
\hline 41 & $1.31 \%$ \\
42 & $2.11 \%$ \\
43 & $2.31 \%$ \\
44 & $2.00 \%$ \\
45 & $11.46 \%$ \\
46 & $2.27 \%$ \\
47 & $1.88 \%$ \\
48 & $1.79 \%$ \\
49 & $4.75 \%$ \\
50 & $4.65 \%$ \\
51 & $1.61 \%$ \\
52 & $0.01 \%$ \\
53 & $7.92 \%$ \\
54 & $4.39 \%$ \\
55 & $6.30 \%$ \\
56 & $5.78 \%$ \\
57 & $10.30 \%$ \\
58 & $11.97 \%$ \\
59 & $17.19 \%$ \\
60 & $17.19 \%$ \\
\hline Percent of total for culverts 41 to 60 \\
\hline
\end{tabular}




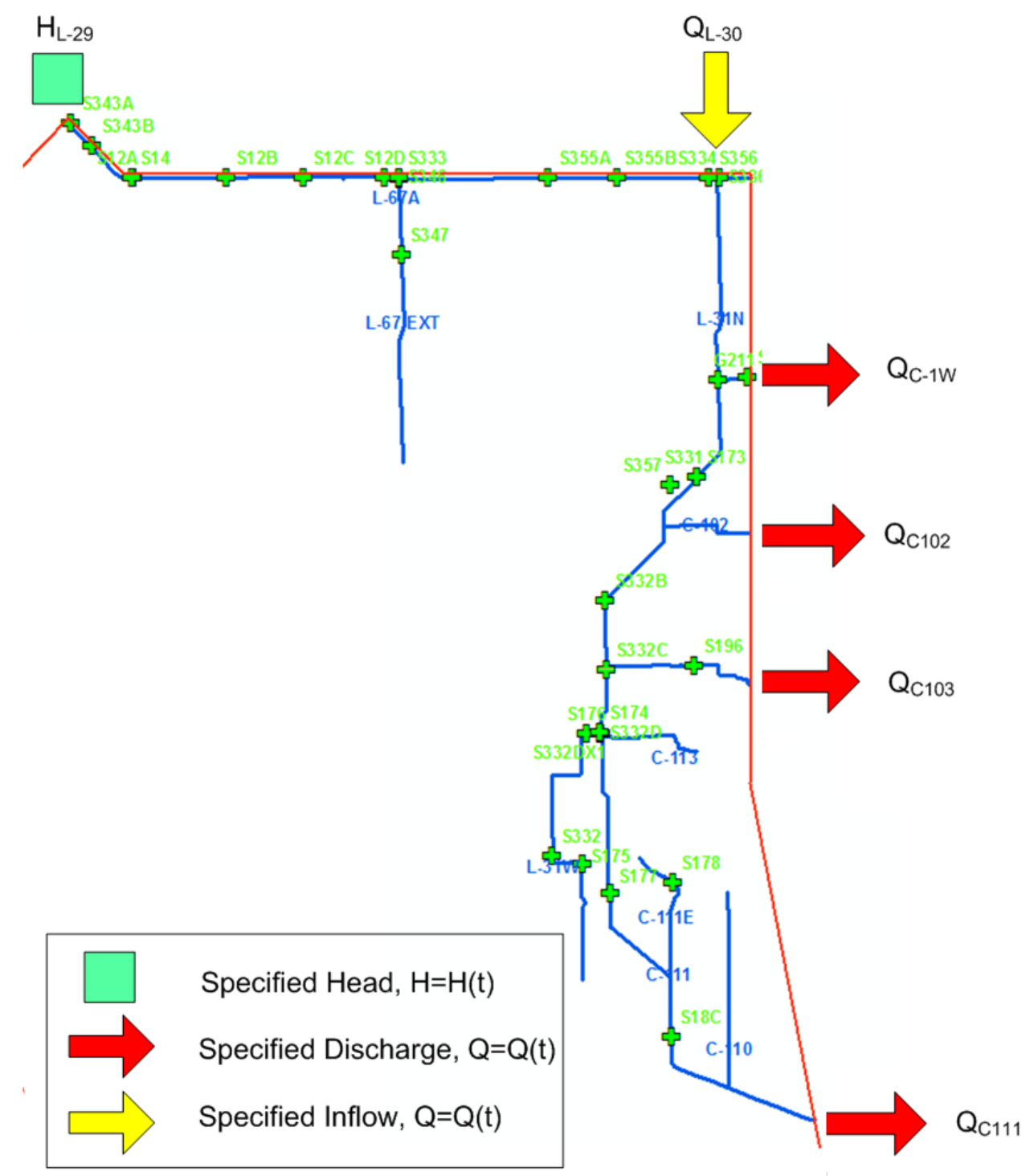

Figure 4.2: MIKE 11 boundary conditions. Green square - water level boundary conditions, yellow arrow - inflow discharge boundary condition, red arrow - mostly out flow discharge boundary condition)

\subsubsection{Control structures}

The canal network in the model domain has numerous structures and culverts to manage the flow and canal levels. For the calibration period, 1987-1997, some structures were not included in the model because they had either not been built during 


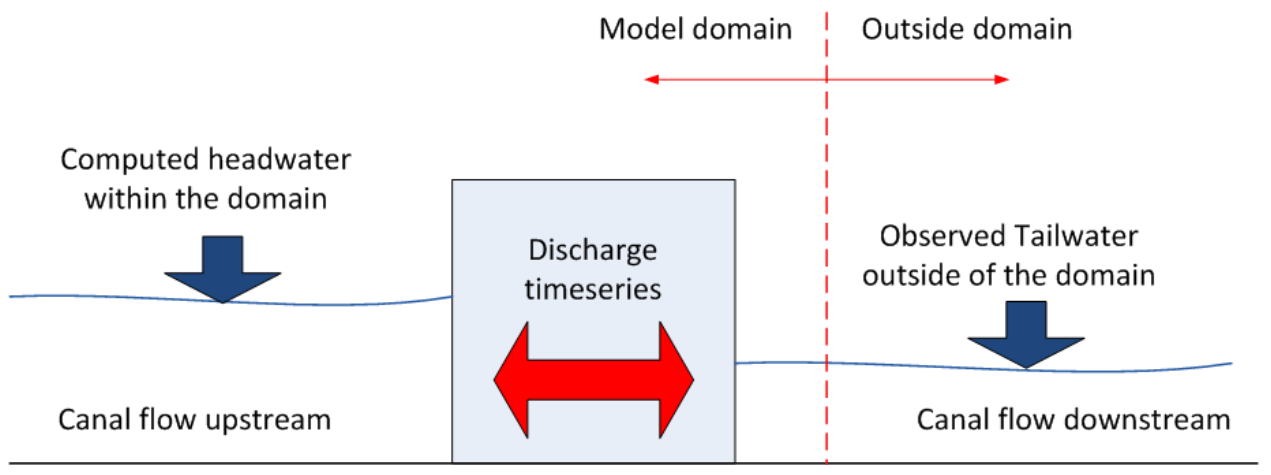

Figure 4.3: Implementation of canals at the domain boundary in MIKE 11

this period, or they did not have a significant impact on the flows and water levels within the domain. Structures within the model served different roles: discharge into the domain, discharge out of the domain, or operation based on schedules. Structures discharging into or out of the domain were implemented using historical time series data. These structures are listed in Tables 4.2 and 4.3, respectively. Structures which were implemented based on operational schedules are listed in Table 4.4, and structures included in the MIKE 11 model as underflow in Table 4.5.

Table 4.2: Structures used for boundary condition input

\begin{tabular}{lll}
\hline Structure & Canal & Note \\
\hline S332 & L-31W & Discharge time series for the pumps \\
S12A & L-29 & Discharge into ENP based on time series \\
S12B & L-29 & Discharge into ENP based on time series \\
S12C & L-29 & Discharge into ENP based on time series \\
S12D & L-29 & Discharge into ENP based on time series \\
S334 & L-29 & Input in the domain, TW used to \\
& & open and close \\
S335 & L-30 & Input in the domain \\
S343A & L-29 & Gated culvert \\
S343B & L-29 & Gated culvert \\
L-29 Culverts & L-29 & A series of culverts discharging from L-29 into \\
& & ENP \\
Seepage from & L-31N & Combination of flow and seepage \\
WCA3B & & \\
\hline
\end{tabular}


Table 4.3: Structures used for boundary condition output

\begin{tabular}{lll}
\hline Structure & Canal & Note \\
\hline S194 & C-102 & $\begin{array}{l}\text { Model discharges from the domain based on } \\
\text { time series }\end{array}$ \\
S196 & C-103 & $\begin{array}{l}\text { Model discharges from the domain based on } \\
\text { time series }\end{array}$ \\
S197 & C-111 & $\begin{array}{l}\text { Model discharges from the domain based on } \\
\text { time series } \\
\text { Model discharges from the domain based on } \\
\text { time series } \\
\text { S338 }\end{array}$ C-1W \\
S336 & C-4 & $\begin{array}{l}\text { Model discharges from the domain based on } \\
\text { time series, the flow through this station is } \\
\text { mostly zero }\end{array}$ \\
\hline
\end{tabular}

Table 4.4: Structures implemented with operational rules

\begin{tabular}{lll}
\hline Structure & Canal & Function \\
\hline G211 & L-31N & At intersection of L-31N levee and C-1N levee \\
S173 & L-31N & Culvert on levee L-31N at site of current S331 \\
S174 & L-31W & $\begin{array}{l}\text { Spillway on levee L-31N near its junction with } \\
\text { C-111 }\end{array}$ \\
S175 & L-31W & Culvert on levee L-31W near FL Highway 27 \\
S177 & C-111 & Spillway on canal C-111 near FL Highway 27 \\
S178 & C-111E & Spillway on canal C-111E near FL Highway 27 \\
S18C & C-111 & Canal 111 at S18C near Florida city, FL \\
S331 & L-31N & Pump station in L-31N borrow canal about 9 \\
& & miles north of Homestead \\
S176 & C-111 & Gated Spillway on C-111 \\
\hline
\end{tabular}

Table 4.5: Structures implemented in MIKE 11 as underflow [6]

\begin{tabular}{ccccc}
\hline ID & Branch & Gates & Width (ft) & Sill Level (ft NGVD) \\
\hline G211 & L-31N & 6 & 6 & -2.5 \\
S173 & L-31N & 1 & 6 & -2.5 \\
S174 & L-31W & 1 & 16 & -1.5 \\
S176 & C-111 & 1 & 20 & -1 \\
S177 & C-111 & 1 & 22 & -7.1 \\
S18C & C-111 & 2 & 22 & -7 \\
S197-03 & C-111 & 3 & 7 & -8 \\
S197-10 & C-111 & 7 & 7 & -8 \\
S197-13 & C-111 & 3 & 7 & -8 \\
S333 & L-29 & 1 & 29 & -3.1 \\
S334 & L-29 & 1 & 29 & -6.9 \\
\hline
\end{tabular}




\subsubsection{Detention areas}

Detention areas and the associated pumps, weirs, and culverts included in the model and constructed and/or planned under the Central and Southern Florida Project and Comprehensive Everglades Restoration Plan are outlined in the following sections [26-28]. The detention areas are implemented as a broad, shallow canal which extends from the southern end of C-357 at the S357 pump to S332D (Frog Pond) Cell 3. Figure 4.4 shows the configuration of detention areas in grey and the canal in blue. All detention areas are currently included in the model; however, there is an option to include the detention areas in sections as a function of the time they were built. Canal cross sections define the boundaries of the detention areas, see Figure 4.5. The implementation within MIKE 11 allows for a more accurate representation of the detention area geometry and a more accurate calculation of detained volumes than using overland flow cells.

S357 detention area: The S357 detention area includes an inflow weir along the north end of the detention area (W-S359) which connects the detention area with the S357 getaway. The weir is $400 \mathrm{ft}$ long and 9.5 NGVD29 high. Water is pumped from C-357 to the getaway, via the S357 pump, and reaches the detention area via the S359 weir. Two outflow weirs (W-S360W and W-360E) are located along the southern end of the detention area. W-360W has a length of $350 \mathrm{ft}$ and a height $11.0 \mathrm{ft}$ NDVG29. W-360E has a length of $350 \mathrm{ft}$ with a height of $10.5 \mathrm{ft}$ NGVD29. The weirs are implemented with no overflow.

C-357 is a seepage collection canal. The canal is implemented with a closed boundary on the north, a pump on the south, and is recharged by groundwater infiltration. Overland flow is not active and the canal does not directly collect 

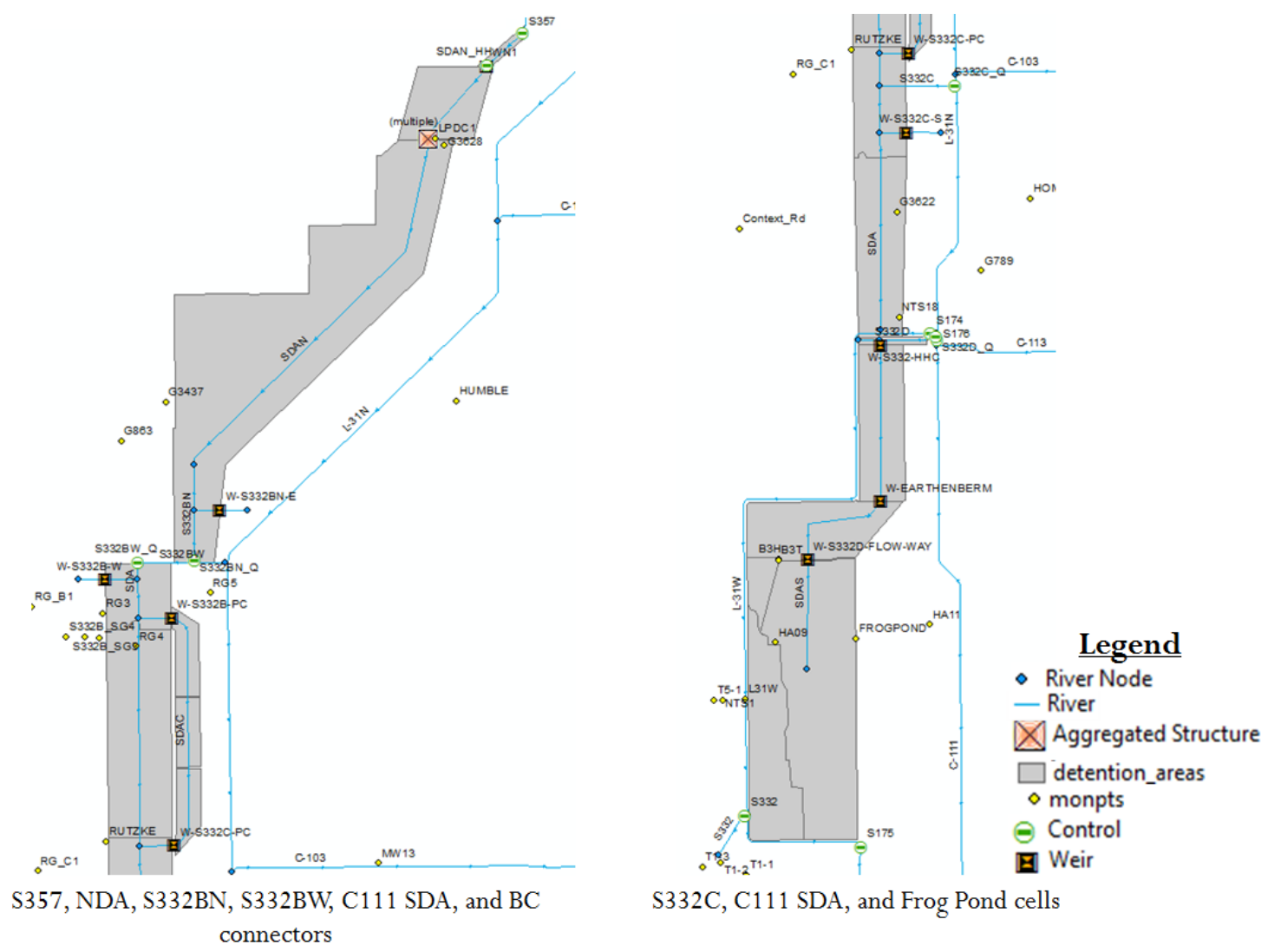

Figure 4.4: Configuration of detention areas along with associated pumps, weirs, and culverts. The canal which provides the shape of the each area is shown in blue

surface water runoff. The S357 pump operations control the water level within the canal and prevents overland flow.

C-111 North Detention Area: The C-111 North Detention Area is currently in the planning phase. The area is included in the model for the analysis of future restoration and operation scenarios.

S332BN: The S332BN detention area is implemented with an emergency outflow weir along the eastern side (W-S332BN-E). The weir is approximately $400 \mathrm{ft}$ long with a height of $11 \mathrm{ft}$ NGVD29. The southern boundary includes a control structure which discharges water into the S332BW detention area (S332BN-Q). 


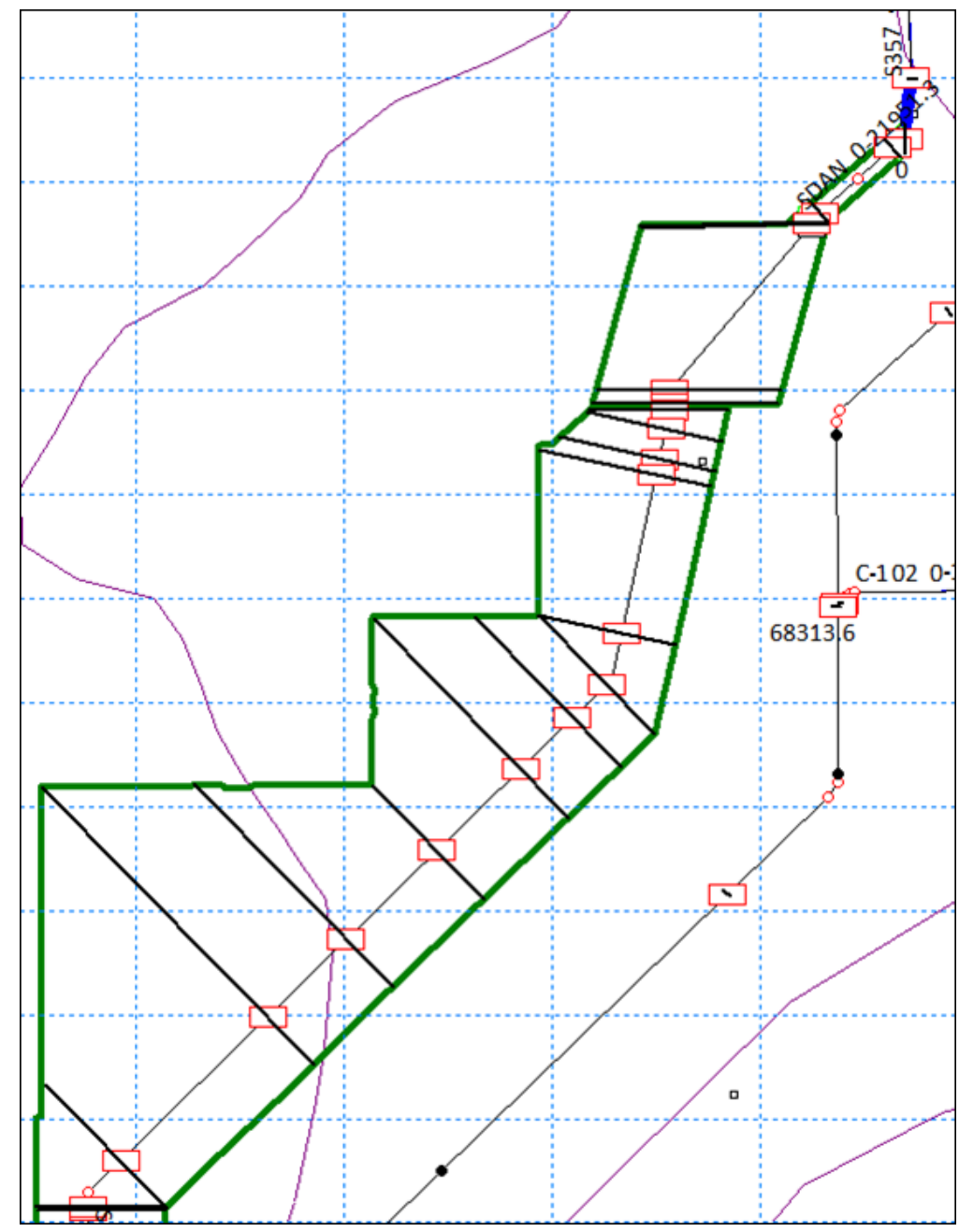

Figure 4.5: Canal cross sections defining the S357 and C-111 NDA

S332BW: The north side of the S332BW detention area includes a control structure to release discharge from the S332BN detention area (S332BW-Q). The west side of the area has a 1,500 ft by $9 \mathrm{ft}$ emergency outflow weir (W-S332B-W). The east side includes 8 culverts and a $350 \mathrm{ft}$ long, $9.5 \mathrm{ft}$ NGVD29 high weir. The connector culverts are $66 \mathrm{ft}$ long, with a diameter of $4 \mathrm{ft}$. The culverts are currently not included in the model.

S332 partial connectors: Current construction includes only the S332B partial connector and the S332C partial connector. The USACOE plans to join the 
partial connectors and create one large southern detention area (SDAC). The model currently implements the entire SDAC detention area.

The model includes a weir (W-S332B-PC) along the S332BW and S332B partial connector, north half, boundaries. The model also implements the weir (W-S332CPC) between the S332C detention area and the S332C partial connector, south half, boundaries. The weir is $500 \mathrm{ft}$ long with a height of $3.6 \mathrm{ft}$. There are also 15 culverts between the connector and detention area. The model does not currently include the culverts.

S332C detention area: The $\mathrm{S} 332 \mathrm{C}$ detention area receives flow along the east side from the weir adjoining the S332C partial connector (W-S332C-PC), as well as flow from pump S332C discharging from L-31N. An overflow weir along the southern east side of the detention area (W-S332C-S) provides a discharge outlet. The weir is $1,500 \mathrm{ft}$ long and $4.1 \mathrm{ft}$ high.

S332D high head cell: The S332D high head cell receives discharge from the S332D pump. The high head cell is implemented as an additional canal and the area of the cell is defined by the canal cross sections. There is a weir along the south side of the cell (W-S332-HHC) which is $1900 \mathrm{ft}$ long and $8.1 \mathrm{ft}$ NGVD29 high. The weir connects the high head cell with S332D cell 1.

S332D Cell 1 and Cell 2: The S332D Cell 1 detention area has an earthen berm (W-EARTHENBERM) along the south side with a length of 2,100 ft and a height of $6.5 \mathrm{ft}$ NGVD29. The berm is implemented as a weir and connects Cell 1 with Cell 2.

Cell 2 has a 1,900 ft long, $6 \mathrm{ft}$ NGVD29 high, weir (W-S332D-FLOW-WAY) along the south side. The weir connects Cell 2 with S332D Cell 3.

S332D Cell 3: S332D Cell 3, also called Frog Pond or Flow Way, is the southern most detention area. Flow is received across the weir joining the S332D Cell 2 and 
Cell 3 (W-S332D-FLOW-WAY). The canal is implemented in the model to represent flow through the detention areas and ends in the center of Cell 3.

\subsection{MIKE SHE}

The MIKE SHE component is a distributed, three-dimensional saturated and unsaturated groundwater flow model with two-dimensional overland/sheet flow which uses Richard's equation and known van Genuchten's parameters to determine flow in the unsaturated zone (UZ). Using the law of conservation of mass and the laws of momentum and energy (three-dimensional Boussinesq and transport equations), MIKE SHE solves the subsurface flow and transport by coupling several partial differential equations (PDEs) which describe flow in the saturated zone (SZ) and UZ with overland and channel flow. Different numerical solution schemes are then used to solve the different PDEs for each process. A solution to the system of equations associated with each process is found iteratively by use of different numerical solvers [29].

Coupling of the MIKE 11 and MIKE SHE model is defined through leakage factors. Leakage factors define the exchange between the overland and subsurface flow and flow within the canals. The actual model coupling is provided in MIKE 11, which specifies the branches to be coupled and the leakage coefficient. The initial values of the leakage factors for infiltration in the UZ were obtained from previous literature data [11]. The exchange between the overland flow and the SZ are based on the hydraulic conductivity of SZ. This parameter is one of the calibration variables. The flow exchange between the canal and groundwater is shown in Figure 4.6. A leakage factor of 0.0002 was used for the canals with the exception of C-111 (0.001), L-29 (0.002), and the L-67 EXT (2.00E-05). 

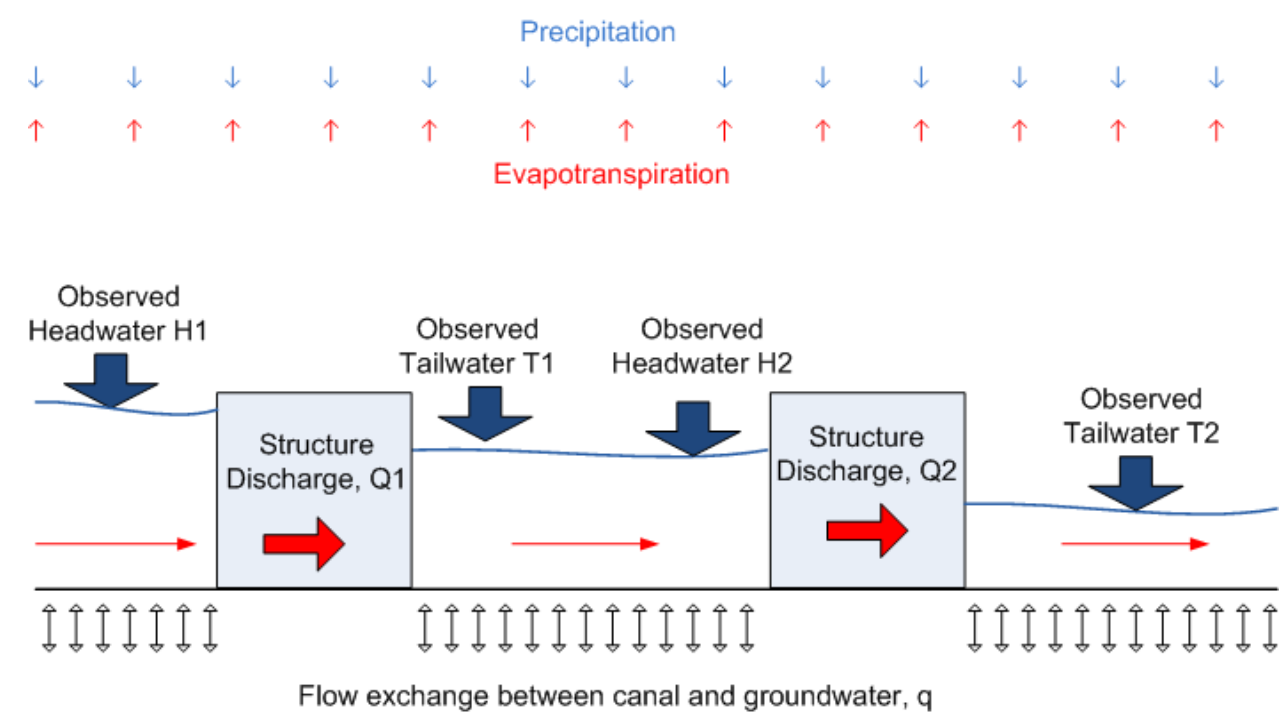

Figure 4.6: MIKE SHE and MIKE 11 exchange

\subsubsection{Soil}

The models initial soil coverage was derived from STATSGO [13] and MDCSM [14]. The GIS files for both the STATSGO and MDCSM maps were combined and implemented in the model. The coverage is shown in Figure 4.7. Labels and relevant attributes of soils found within the model domain are listed in Table 4.6.

The MIKE SHE model primarily uses values for the unsaturated parameters of Loamy Sand, Sand, and Peat soil types. The typical moisture retention curves in Figure 4.8 show the drainage curve, the matric potential as a function of moisture content. The hydraulic conductivity of sand soils, which are characterized with rapid drainage, is strongly dependent on the moisture content and small changes of the moisture content lead to a rapid decrease of the hydraulic conductivity. Peat and similar soils show a higher moisture content at any potential compared to the other primary types of soils available in the MIKE SHE database.

The combined soil coverage map was greatly simplified by NPS personnel [25] based on the properties of soil types found within ENP. Reducing the number of 


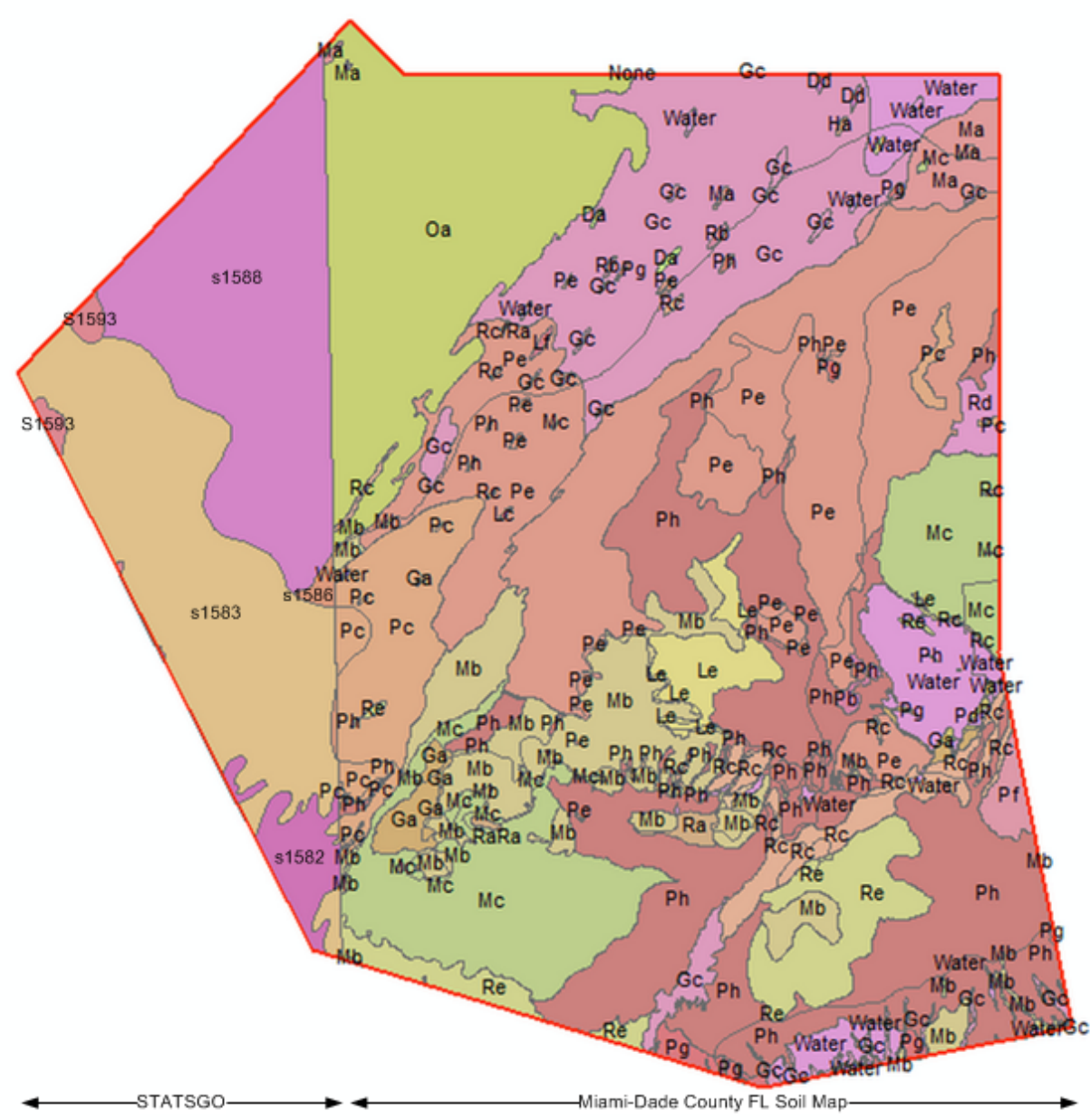

Figure 4.7: Soil coverage of the study area. STATSGO and MDCSM combined soil coverage used as initial soil coverage in the model $[13,14]$

soil types in the model resulted in better run times without having a significant effect on the overall model response. The soil profiles implemented in the model were grouped into five categories and are shown in Figure 4.9: Marl, Gandy Peat, Everglades Peat, Mangrove Peat, and Rockale. 
Table 4.6: Hydraulic parameters of soils in the unsaturated zone [29]

\begin{tabular}{lccccc}
\hline Type & $\theta$ res & $\theta$ sat & $\alpha, \mathrm{cm}^{-1}$ & $\mathbf{n}$ & $K_{\text {sat }}, \mathbf{f t} /$ day \\
\hline Sand & 0.045 & 0.43 & 0.145 & 2.68 & 23.39 \\
Loamy Sand & 0.057 & 0.41 & 0.124 & 2.28 & 11.49 \\
Loam & 0.078 & 0.43 & 0.036 & 1.56 & 0.82 \\
Silt Loam & 0.067 & 0.45 & 0.02 & 1.41 & 0.35 \\
Sandy Clay Loam & 0.1 & 0.39 & 0.059 & 1.48 & 1.03 \\
Clay Loam & 0.095 & 0.41 & 0.019 & 1.31 & 0.2 \\
Silty Clay Loam & 0.089 & 0.43 & 0.01 & 1.23 & 0.06 \\
Loam & 0.078 & 0.43 & 0.036 & 1.56 & 0.82 \\
Sandy Clay & 0.1 & 0.38 & 0.027 & 1.23 & 0.09 \\
Silty Clay & 0.07 & 0.36 & 0.005 & 1.09 & 0.02 \\
Peat & 0.1 & 0.7 & 0.05 & $1.1-1.3$ & $0.05-1$ \\
\hline
\end{tabular}
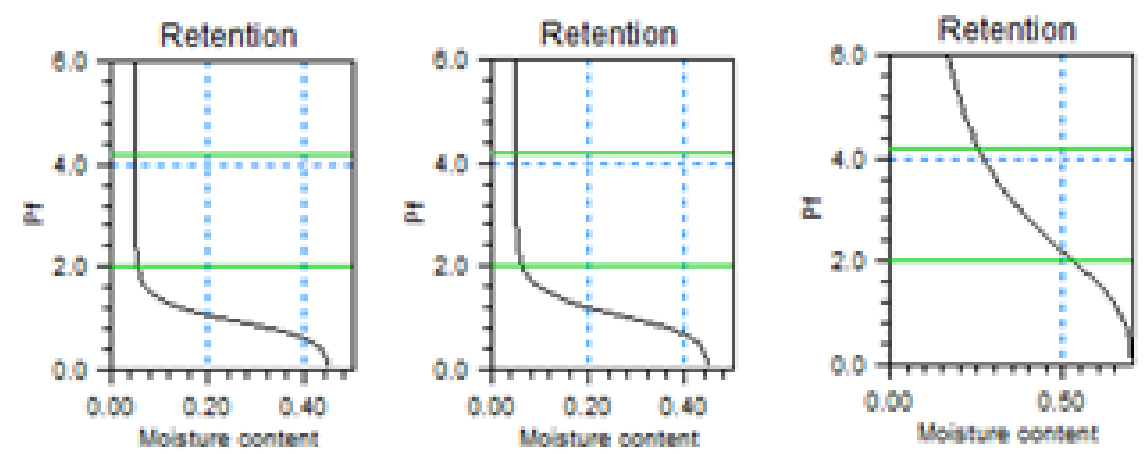

Figure 4.8: Moisture retention curves (matric potential/moisture content) for the three primary types of soils as available within the MIKE SHE database (from the left: Sand, Sandy Loam, and Peat) 


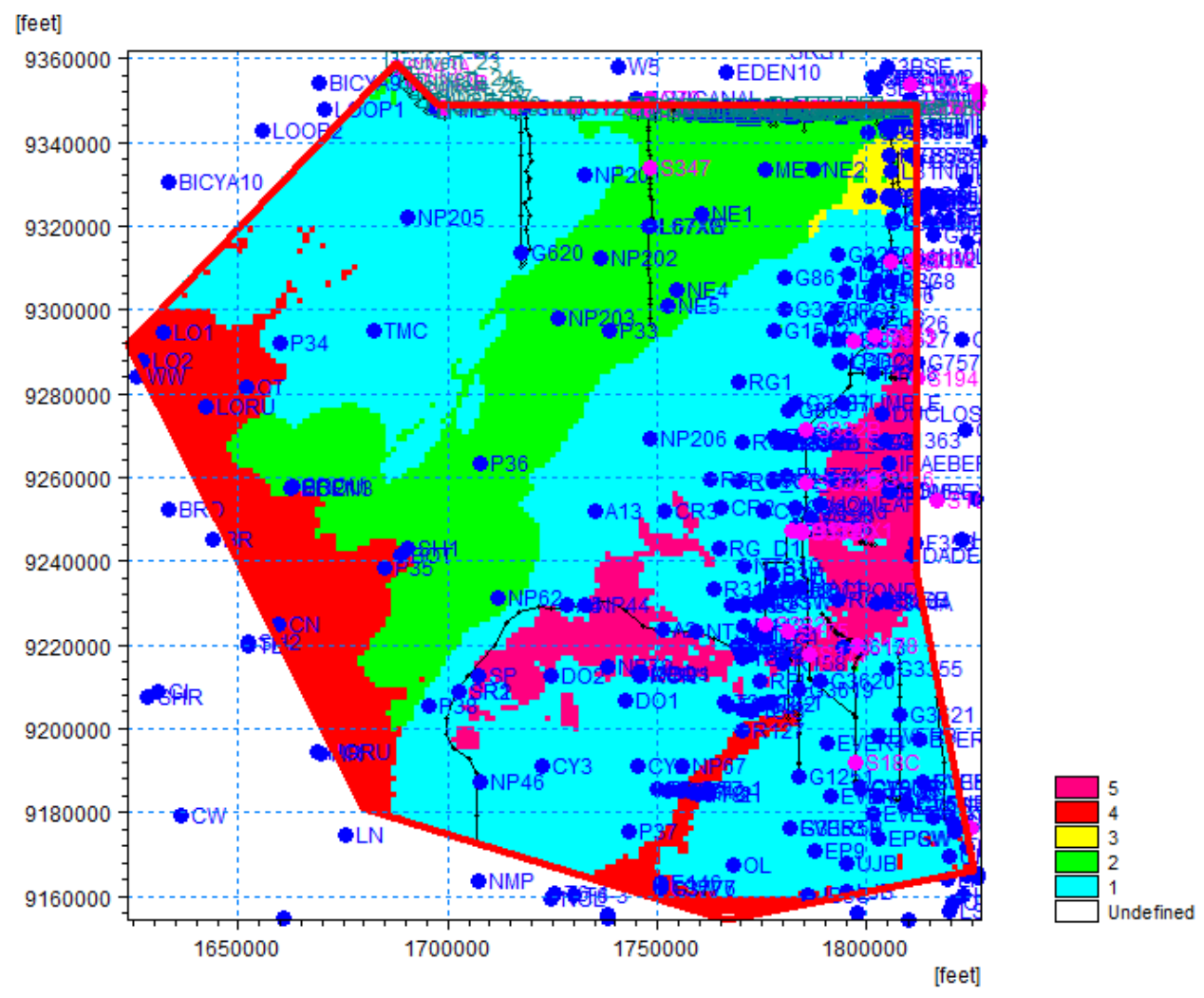

Figure 4.9: Soil classifications implemented in the model. 1. Marl, 2. Gandy Peat, 3. Everglades Peat, 4. Mangrove Peat, 5. Rockdale [25] 


\subsubsection{Vegetation}

Vegetation coverage was obtained from the FLGAP coverage map as shape files (more than 100,000 polygons with approximately 80 classes of vegetation). The shape files were merged into a single shape file, clipped according to the model domain, and used in MIKE SHE for the classification of the vegetation.

Considering that the FLGAP has more than 70 categories, the vegetation types were divided into nine major categories based on similar LAI, RD and crop coefficient $K_{c}$ values. Initially, the LAI was seasonally adjusted between 3, 3.5 and 4, while $K_{c}$ and $\mathrm{RD}$ were kept constant during the season. A set of simulations was completed with adjustments made to the $K_{c}$ and the RD to improve model response in selected areas. It was found that the model was sensitive to LAI, but showed very little sensitivity to RD. The model was calibrated using a seasonally adjusted $K_{c}$, a constant $\mathrm{RD}$, and seasonally varied LAI values as shown in Table 4.7. Figure 4.10 shows the distribution of the vegetation types used as model input.

Table 4.7: Vegetation parameters used for calibration

\begin{tabular}{lccc}
\hline Type & $\left(K_{c}\right)$ & LAI & RD, in \\
\hline Emergent March & $0.9-1.2$ & $3-4$ & 29.53 \\
Wet Prairie & $0.76-0.84$ & $2-3$ & 39.37 \\
Sawgrass & $0.65-0.76$ & $3-4$ & 23.62 \\
Open Water & 1.2 & 0 & 0 \\
Hammock & 1 & $3-4$ & 68.90 \\
Mangrove & $1-1.1$ & $3-4$ & 70.87 \\
Pine Forest & 1 & $3-4$ & 49.21 \\
Ag and Urban & 1 & $3-4$ & 29.53 \\
Exotics & 1 & $3-4$ & 68.90 \\
\hline
\end{tabular}




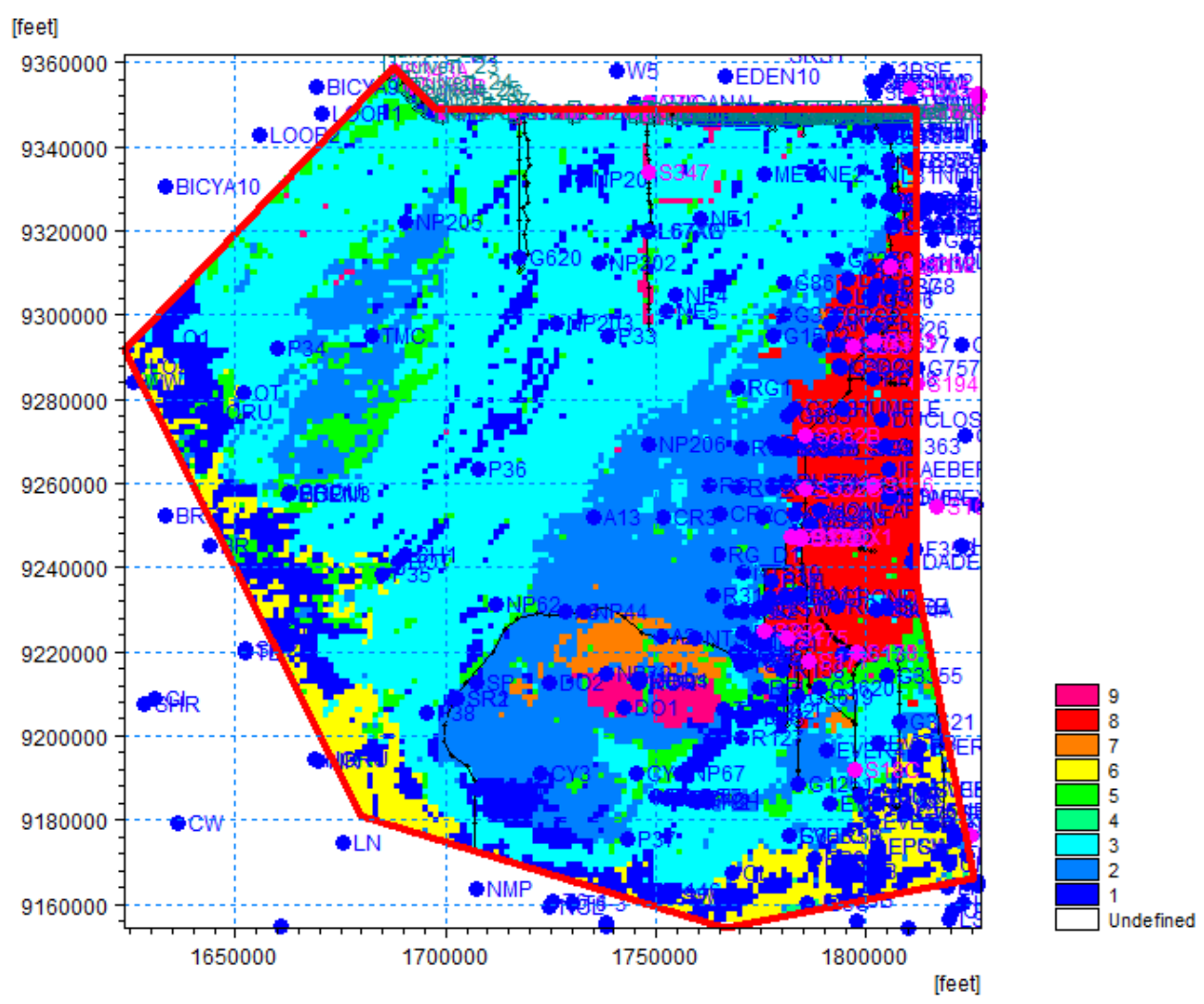

Figure 4.10: Vegetation coverage in the model: 1. Emergent Marsh, 2. Wet Prairie, 3. Sawgrass, 4. Open Water, 5. Hammock, 6. Mangrove, 7. Pine Forest, 8. Agriculture and Urban, 9. Exotics [25]

\subsubsection{Rainfall}

Gridded time series from the SFWMM, provided by NPS, were implemented in the model. A simulation was completed using Thiessen polygons. The model showed a similar response to simulations with gridded time series. The calibrated model uses the gridded data from the SFWMM. 


\subsubsection{Evapotranspiration}

The primary evapotranspiration (ET) model is based on empirically derived equations that follow the work of Kristensen and Jensen [30]. In the Kristensen-Jensen model, the actual ET and the actual soil moisture status in the root zone is calculated from the reference evaporation rate, along with maximum RD and LAI for the plants. The empirical equations in the model are based on actual measurements.

The primary ET model is based on empirically derived equations. Actual ET is the sum of ET from the canopy, ponded water, UZ, and SZ. The actual ET cannot be greater than ET max and the ET is calculated in a specific order until ET max is reached. After the ET is removed from any available snow storage, ET is removed from the canopy storage until the canopy storage is exhausted or ET max is satisfied. If the interception storage cannot satisfy ET max, water is evaporated from the ponded water until the ponded water is exhausted. If ET max has not yet been satisfied, water is removed from the UZ until ET max is satisfied or the water content of the upper UZ layer is reduced to the minimum. If the water table is above the extinction depth, then ET is removed from SZ until ET max is satisfied. Potential ET is the amount of water that could be evaporated and transpired if there were sufficient water available. It represents the ET rate of a short green crop, completely shading the ground, of uniform height and with adequate water status in the soil profile.

The calculation of ET uses meteorological and vegetative data to predict the total ET and net rainfall due to:

- Interception of rainfall by the canopy

- Drainage from the canopy to the soil surface

- Evaporation from the canopy surface 
- Evaporation from the soil surface

- Uptake of water by plant roots and its transpiration, based on soil moisture in the unsaturated root zone

In MIKE SHE, the ET processes are modeled in the following order [29]:

1. A proportion of the rainfall is intercepted by the vegetation canopy, from which part of the water evaporates.

2. The remaining water reaches the soil surface, producing either surface water runoff or percolating to the UZ.

3. Part of the infiltrating water is evaporated from the upper part of the root zone or transpired by the plant roots.

4. The remainder of the infiltrating water recharges the groundwater in the SZ.

The ET calculations include the following parameters:

1. Canopy Interception, typical value is $0.05 \mathrm{~mm}$. This parameter defines the fraction of precipitation which is retained on the leaves, branches, and stems of vegetation, which evaporates directly without adding to the moisture storage in the soil.

2. Evaporation from the Canopy

3. Plant Transpiration

\subsubsection{Overland flow}

Overland flow in MIKE SHE is represented using the diffusive wave approximation of the Saint Venant equations computed in two dimensions. Use of the diffusive wave approximation allows the depth of flow to vary significantly between neighboring 
cells and for the backwater conditions to be simulated. In MIKE SHE, the resistance of the bed to overland flow is defined through the Stickler's coefficient M, which is the inverse of the Manning's n.

Two options are available for the exchange of overland flow with flow in the canal: overbank spilling or flood codes. Both methods are implemented in the model.

The overbank spilling option treats the canal bank as a weir. When the overland flow water level or the river water level is above the left or right bank elevation, then water will spill across the bank based on the standard weir formula. Numerical problems can occur when the slope of the water surface profile is very shallow and the velocities are very low, causing water to form a wall along the bank instead of flowing to neighboring cells as overland flow. Overbank spilling is used for the shallow ditch/berm system used to represent the road at Shark River (Tram Road), the main park road, and the L-67EXT. Overbank spilling was not used for the other canals.

Flood codes are numerically more stable than overbank spilling for shallow water surface profiles and low velocity flow, which represents most of the flow in the model domain. When the MIKE 11 water level is above the topography, the water level of the canal becomes the level of water on the bank of the adjacent cells. Overland flow within the flooded cell is part of the MIKE 11 water balance calculation; however, lateral flow into neighboring non-flooded cells is included in the MIKE SHE calculations for exchange between the overland flow, SZ, and UZ. Flood codes are implemented for the culverts along L-29 and for section of L-67EXT, in addition to overbank spilling. 


\subsubsection{Hydrogeology}

The MIKE SHE model includes the entire SAS. The lower vertical boundary of the model is the top of the ICU. The selection of this boundary was based on the significant change of permeability, which represents a natural vertical boundary condition. The vertical discretization of the MIKE SHE hydrogeological model was developed using two layers:

- A surface layer which accounts for the highly permeable Miami oolite (Qm). Qm overlays the majority of the ENP domain.

- A second layer which includes the remaining SAS.

The bottom of the SAS and Qm were determined by spatial interpolation of transect data published by Fish and Stewart [9]. Figure 4.11 indicates the location of the drill sites and Table 4.8 provides a list of the wells and the corresponding hydrogeologic parameters.

The relation between transmissivity of the SAS and the hydraulic conductivity of several layers is described by equations (4.1) and (4.2) [9]:

$$
\begin{gathered}
T=\sum_{i=0}^{n} T_{i}=\sum_{i=0}^{n} K_{i} b_{i} \\
K=\frac{T}{\sum_{i=0}^{n} b_{i}}
\end{gathered}
$$

Where $T$ is total transmissivity; $T_{i}$ is transmissivity of the $i^{\text {th }}$ layer of total of n layers; $K_{i}$ is hydraulic conductivity of the $i^{\text {th }}$ layer; and $b_{i}$ is thickness of the $i^{t h}$ layer of the $\mathrm{n}$ layers. MIKE SHE requires hydraulic conductivity. The equations were used to determine the horizontal hydraulic conductivity of SAS since 


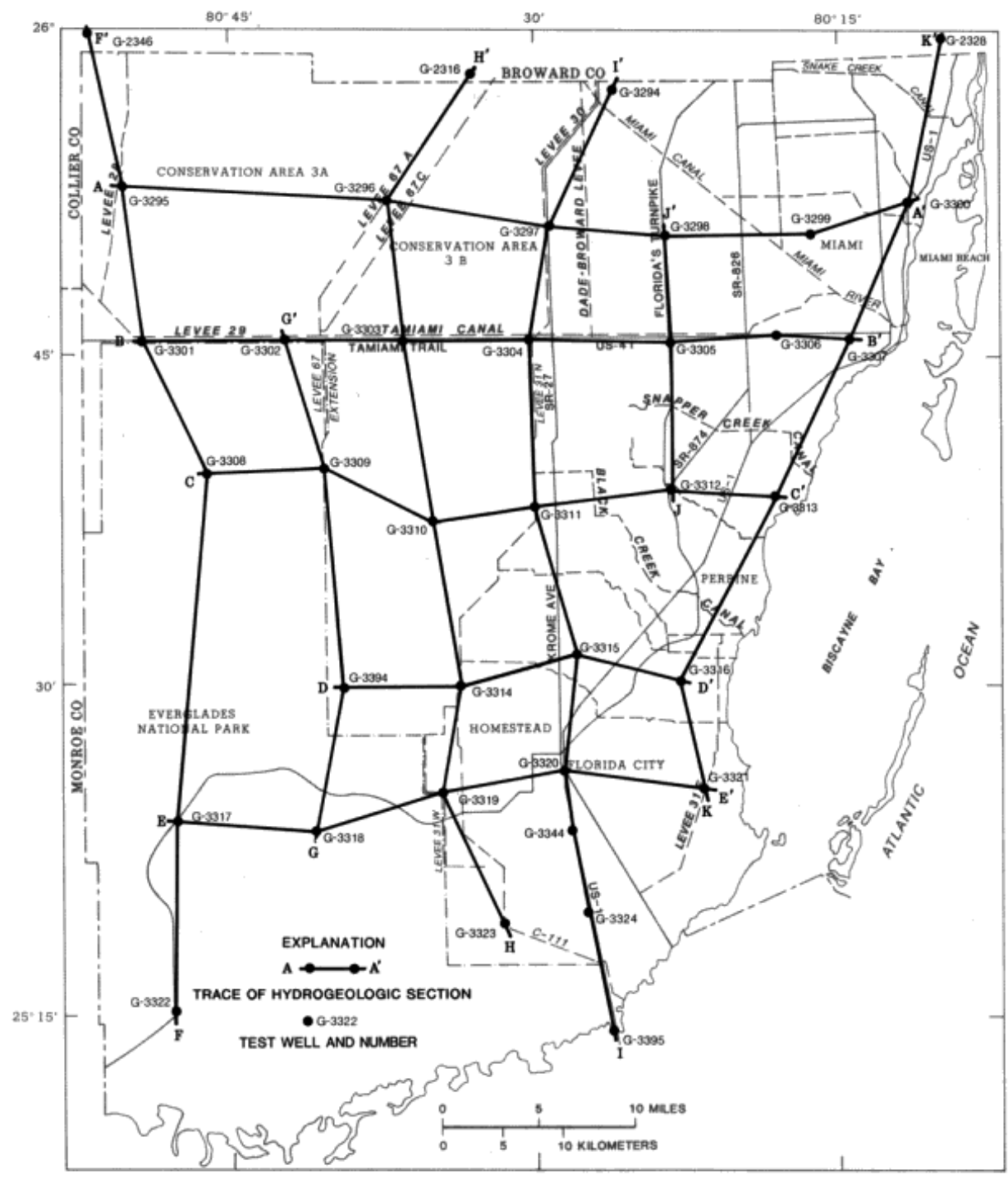

Figure 4.11: Location of USGS well sites where the hydrogeologic parameters listed in Table 4.8 were obtained [9]

Surface maps and model grids of the bottom level and the thickness of each layer and the hydraulic conductivity of the surface layer were generated using triangulation and linear interpolation (Figures 4.12-4.17). Transmissivity measurements (Figure 4.18) were used to provide the gridded spatial interpolation for transmissivity of the Qm and the SAS (Figure 4.19 and Figure 4.20, respectively). 
Table 4.8: List of hydrogeologic parameters [9]

\begin{tabular}{|c|c|c|c|c|c|}
\hline $\begin{array}{l}\text { USGS well } \\
\text { number }\end{array}$ & $\begin{array}{c}\text { State Plane } \\
\text { X Coordinate }\end{array}$ & $\begin{array}{c}\text { State Plane } \\
\text { Y Coordinate }\end{array}$ & $\begin{array}{c}\mathbf{K}_{Q m} \\
\mathbf{f t} / \mathbf{d a y}\end{array}$ & $\begin{array}{l}\text { Qm Depth, } \\
\mathrm{ft}\end{array}$ & $\begin{array}{c}\text { SAS Depth, } \\
\mathrm{ft}\end{array}$ \\
\hline G-2316 & 545179.5 & 2871883 & 1 & 1 & 190 \\
\hline G-2328 & 584332.2 & 2874584 & 10 & 1 & 280 \\
\hline G-2346 & 513390.5 & 2875540 & 1 & 3 & 155 \\
\hline G-3294 & 556988.8 & 2870314 & 100 & 1 & 200 \\
\hline G-3295 & 516208.6 & 2862733 & 1 & 5 & 215 \\
\hline G-3296 & 538170 & 2861325 & 1 & 5 & 180 \\
\hline G-3297 & 551607 & 2858902 & 1 & 6 & 160 \\
\hline G-3298 & 561167.9 & 2858068 & 100 & 8 & 170 \\
\hline G-3299 & 573379 & 2858090 & 10 & 8 & 225 \\
\hline G-3300 & 581523.1 & 2860806 & 10 & 9 & 210 \\
\hline G-3301 & 517805.2 & 2849619 & 1 & 1 & 200 \\
\hline G-3302 & 529631.6 & 2849594 & 1 & 1 & 190 \\
\hline G-3303 & 539430.1 & 2849525 & 10 & 5 & 170 \\
\hline G-3304 & 549922.1 & 2849468 & 1 & 3 & 180 \\
\hline G-3305 & 561714.6 & 2849169 & 1000 & 7 & 170 \\
\hline G-3306 & 570516.8 & 2849538 & 10 & 0 & 210 \\
\hline G-3307 & 576691.8 & 2849220 & 1000 & 1 & 235 \\
\hline G-3308 & 523099.2 & 2838372 & 100 & 3 & 195 \\
\hline G-3309 & 532828.5 & 2838734 & 10 & 2.5 & 200 \\
\hline G-3310 & 541850.5 & 2834197 & 1000 & 10 & 210 \\
\hline G-3311 & 550215 & 2835353 & 1000 & 3 & 180 \\
\hline G-3312 & 561714 & 2836550 & 2000 & 7 & 185 \\
\hline G-3313 & 570319.5 & 2835958 & 1000 & 14 & 145 \\
\hline G-3314 & 544079.7 & 2820272 & 1000 & 8 & 235 \\
\hline G-3315 & 553761.7 & 2822843 & 1000 & 17 & 185 \\
\hline G-3316 & 562319.1 & 2820537 & 1000 & 16 & 145 \\
\hline G-3317 & 520462.8 & 2809047 & 1000 & 5.5 & 170 \\
\hline G-3318 & 532046.1 & 2808117 & 1000 & 11 & 210 \\
\hline G-3319 & 542551.5 & 2811332 & 1000 & 2.7 & 230 \\
\hline G-3320 & 552613.2 & 2813056 & 1000 & 26 & 135 \\
\hline G-3321 & 564278.9 & 2811485 & 1000 & 25 & 170 \\
\hline G-3322 & 520247.3 & 2793054 & 1000 & 5 & 200 \\
\hline G-3323 & 547548.8 & 2800171 & 1000 & 13 & 170 \\
\hline G-3324 & 554666.5 & 2801099 & 1000 & 16 & 170 \\
\hline G-3344 & 553401.2 & 2807983 & 1000 & 15 & 150 \\
\hline G-3394 & 534325.6 & 2820253 & 1000 & 7.5 & 180 \\
\hline G-3395 & 556593.5 & 2791026 & 1 & 25 & 220 \\
\hline G0 & 537000 & 2787000 & 1 & 11 & 210 \\
\hline Fo & 520247.3 & 2783054 & 1 & 5.5 & 170 \\
\hline
\end{tabular}


A one foot layer with low conductivity was identified on the north east section of the domain (Figure 4.21). This layer has been implemented as a geological lens with conductivity of $1 \mathrm{ft} /$ day [25].

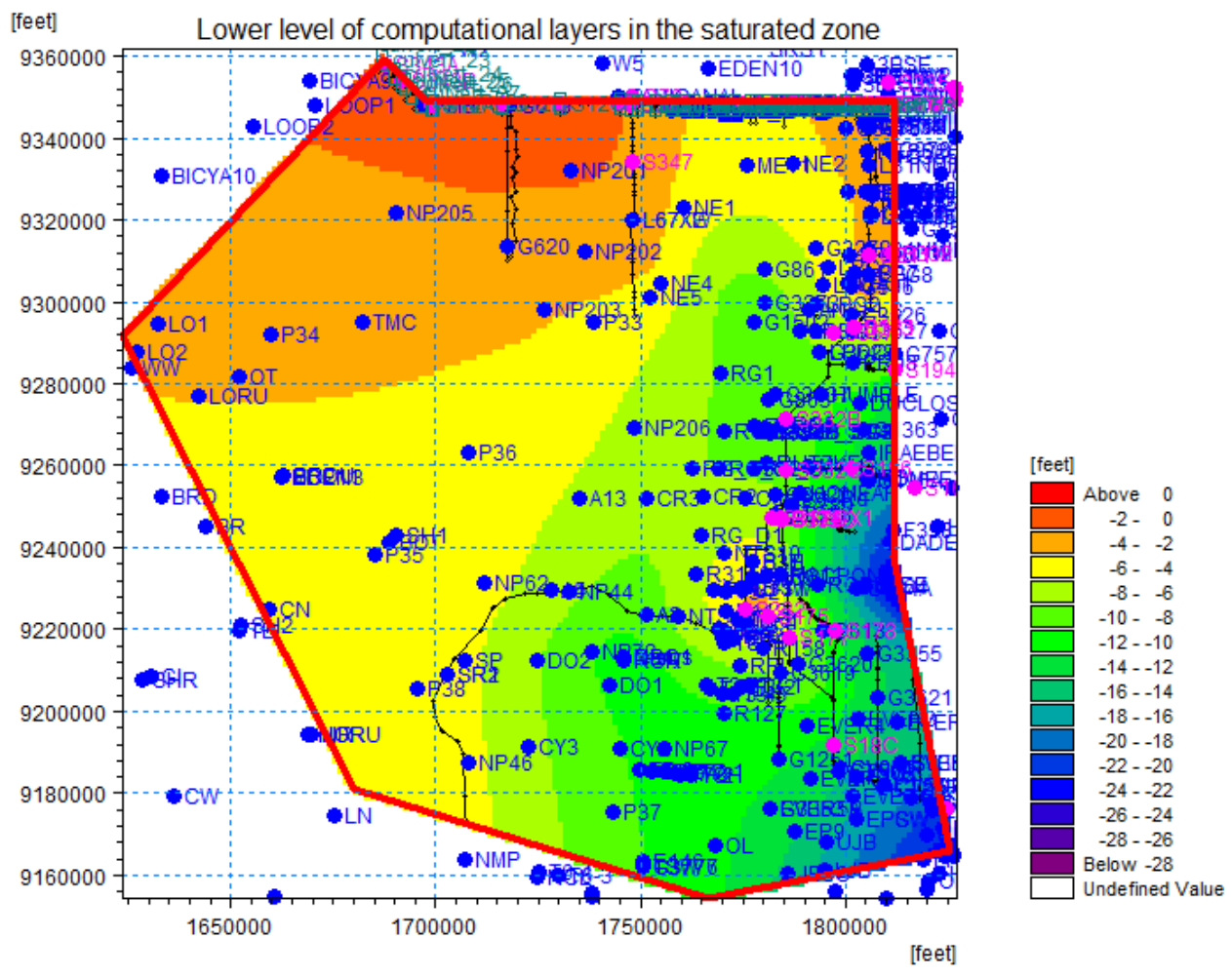

Figure 4.12: Bottom level of layer 1-Miami Oolite 


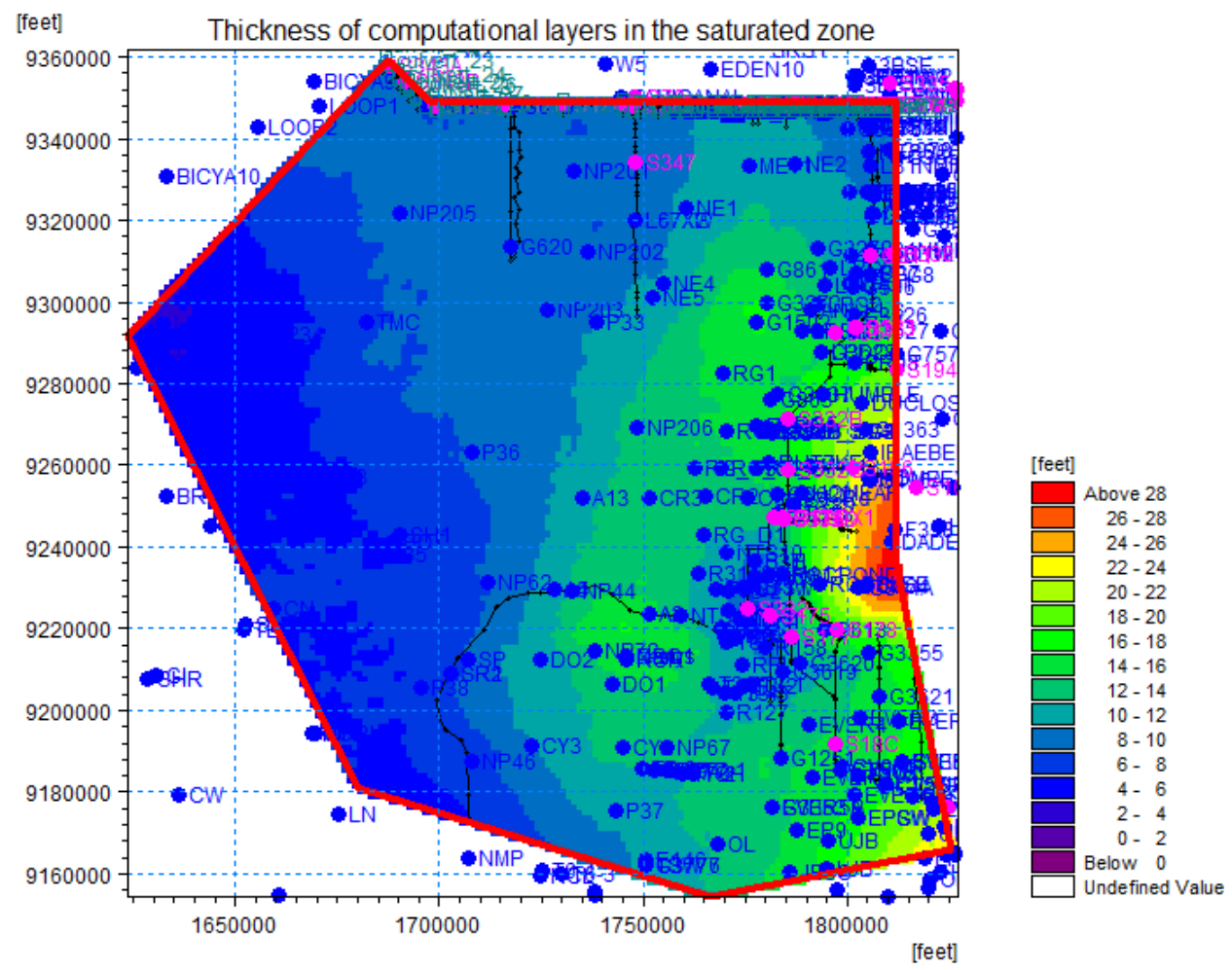

Figure 4.13: Thickness of layer 1-Miami Oolite 


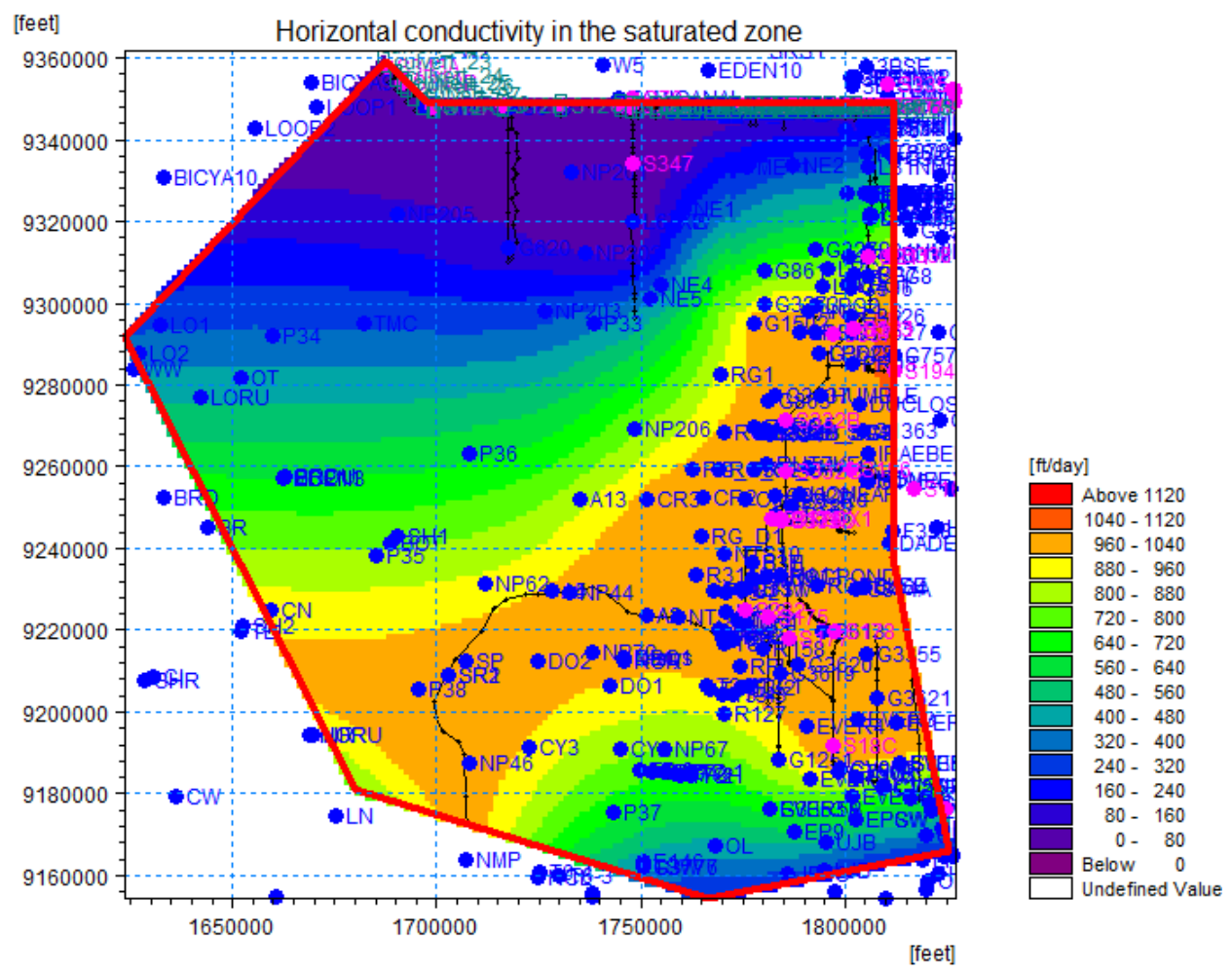

Figure 4.14: Horizontal Conductivity of layer 1-Miami Oolite 


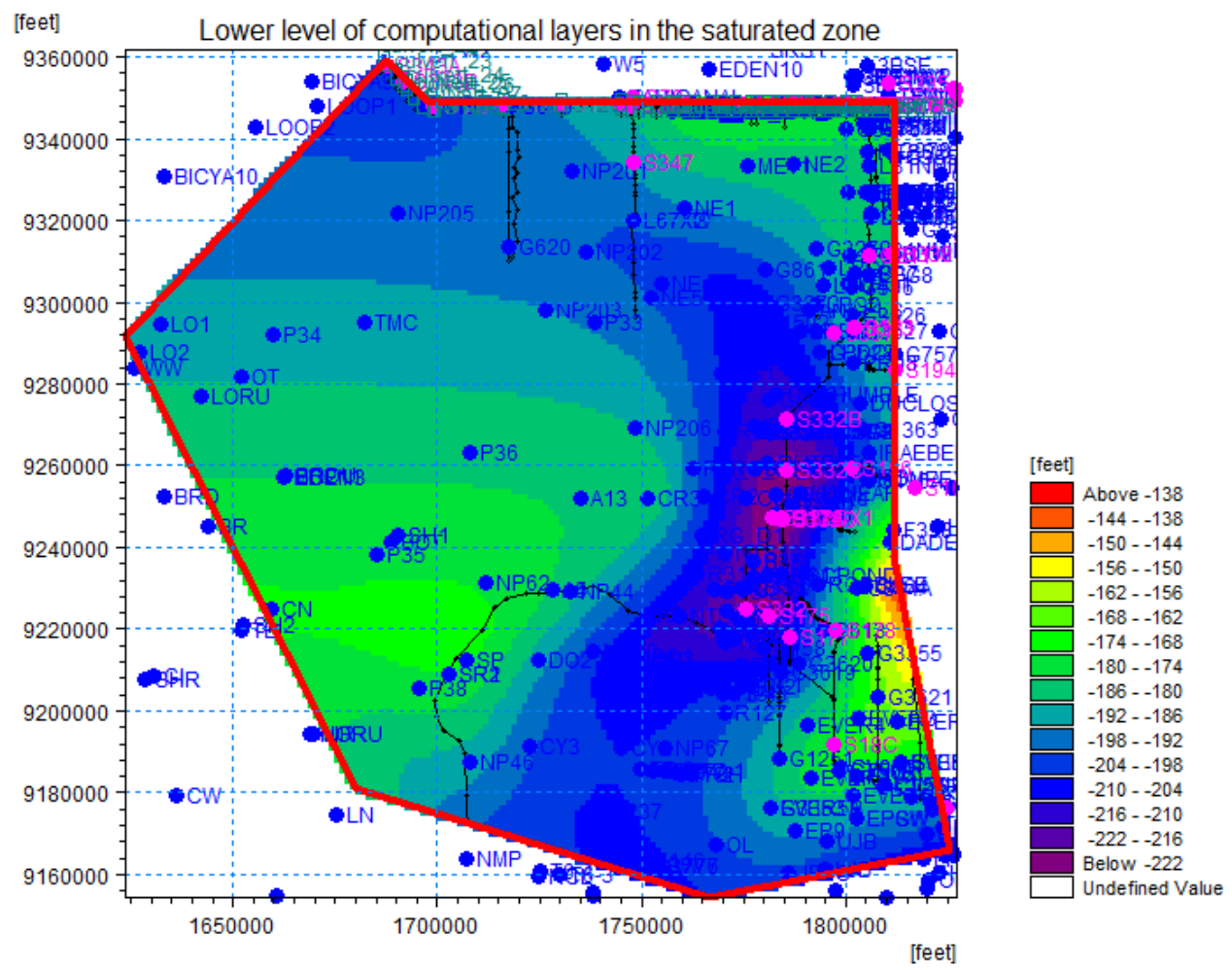

Figure 4.15: Bottom level of layer 2-SAS 


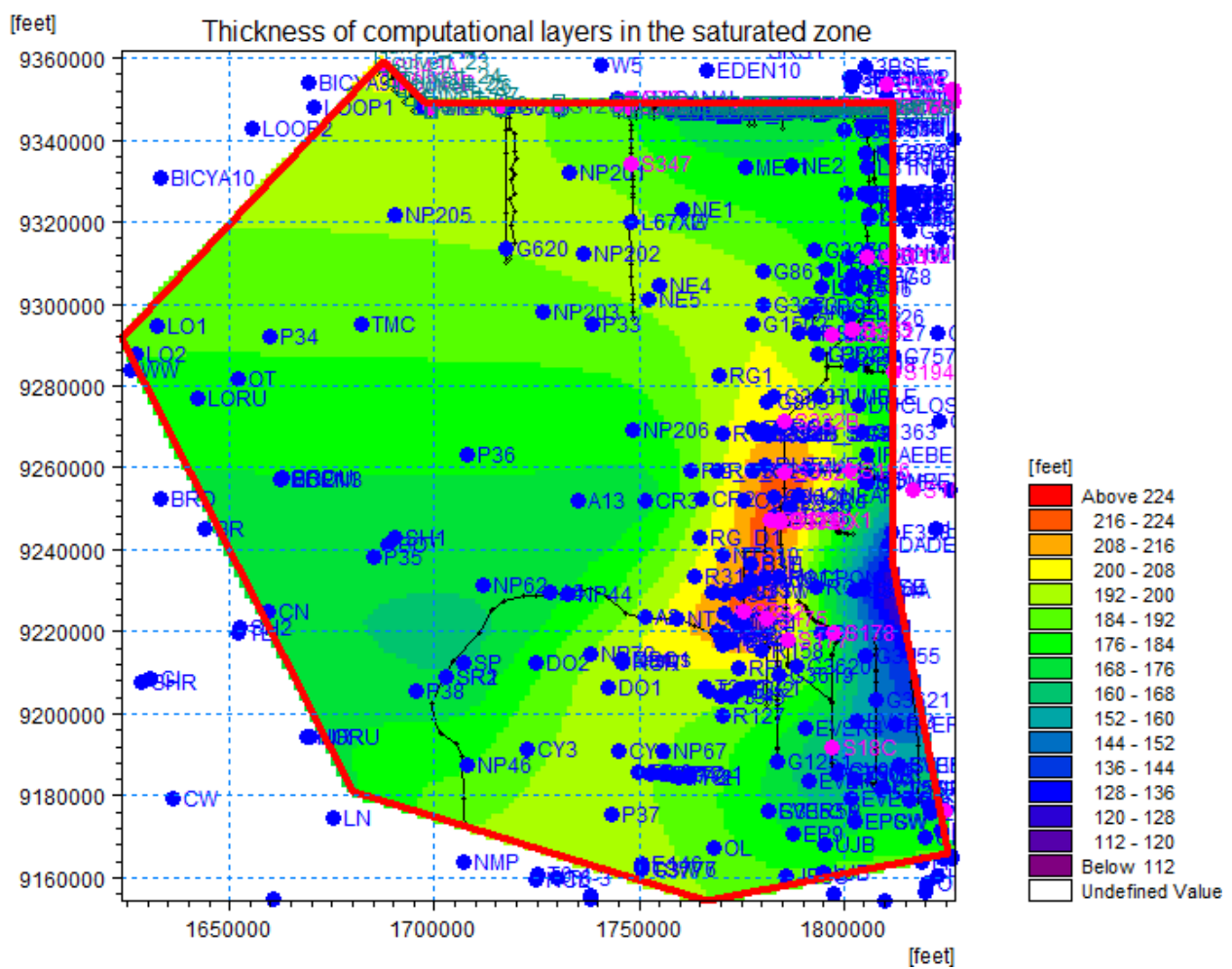

Figure 4.16: Thickness of layer 2-SAS 


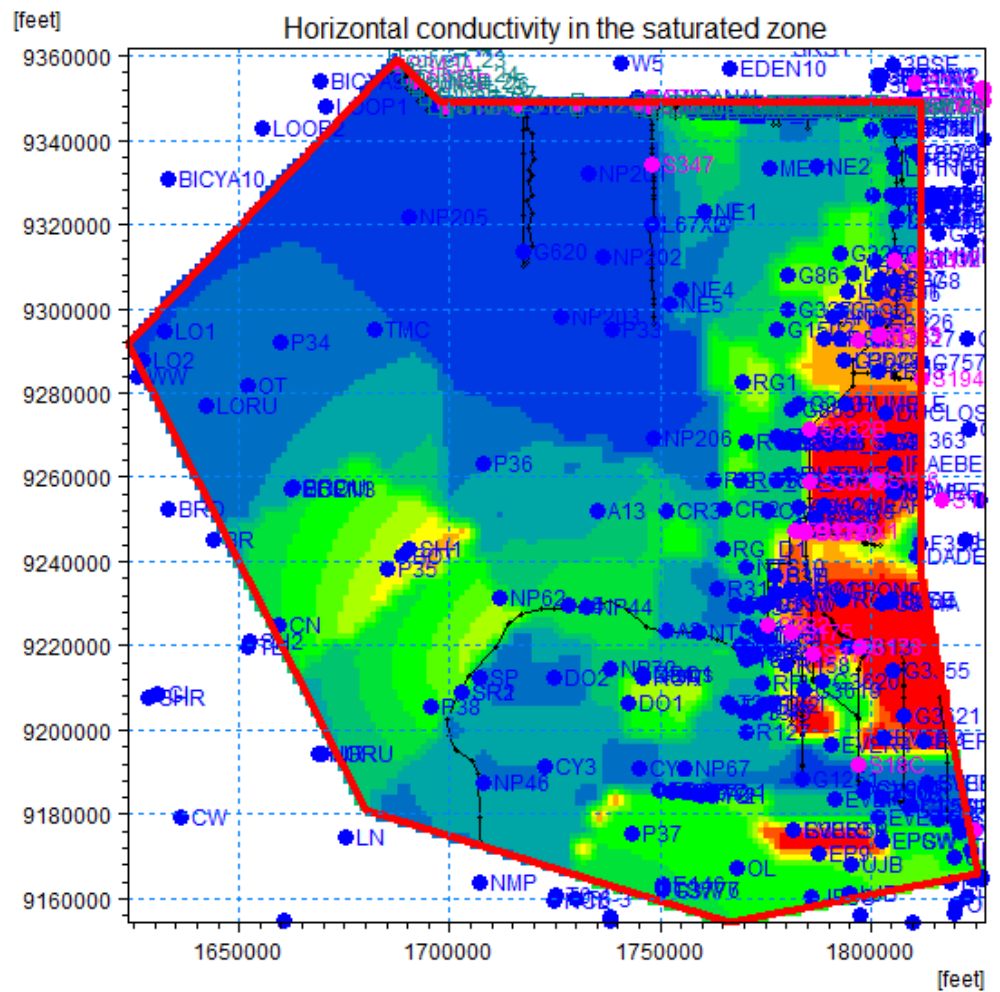

[ft/day]

Above 44000

$40000-44000$

$36000-40000$

$32000-36000$

$28000-32000$

$24000-28000$

$20000-24000$

$16000-20000$

$12000-16000$

$8000-12000$

4000 - 8000

0 - 4000

$-4000-\quad 0$

$-8000--4000$

$-12000--8000$

Below -12000

Undefined Value

Figure 4.17: Horizontal Conductivity of layer 2-SAS 


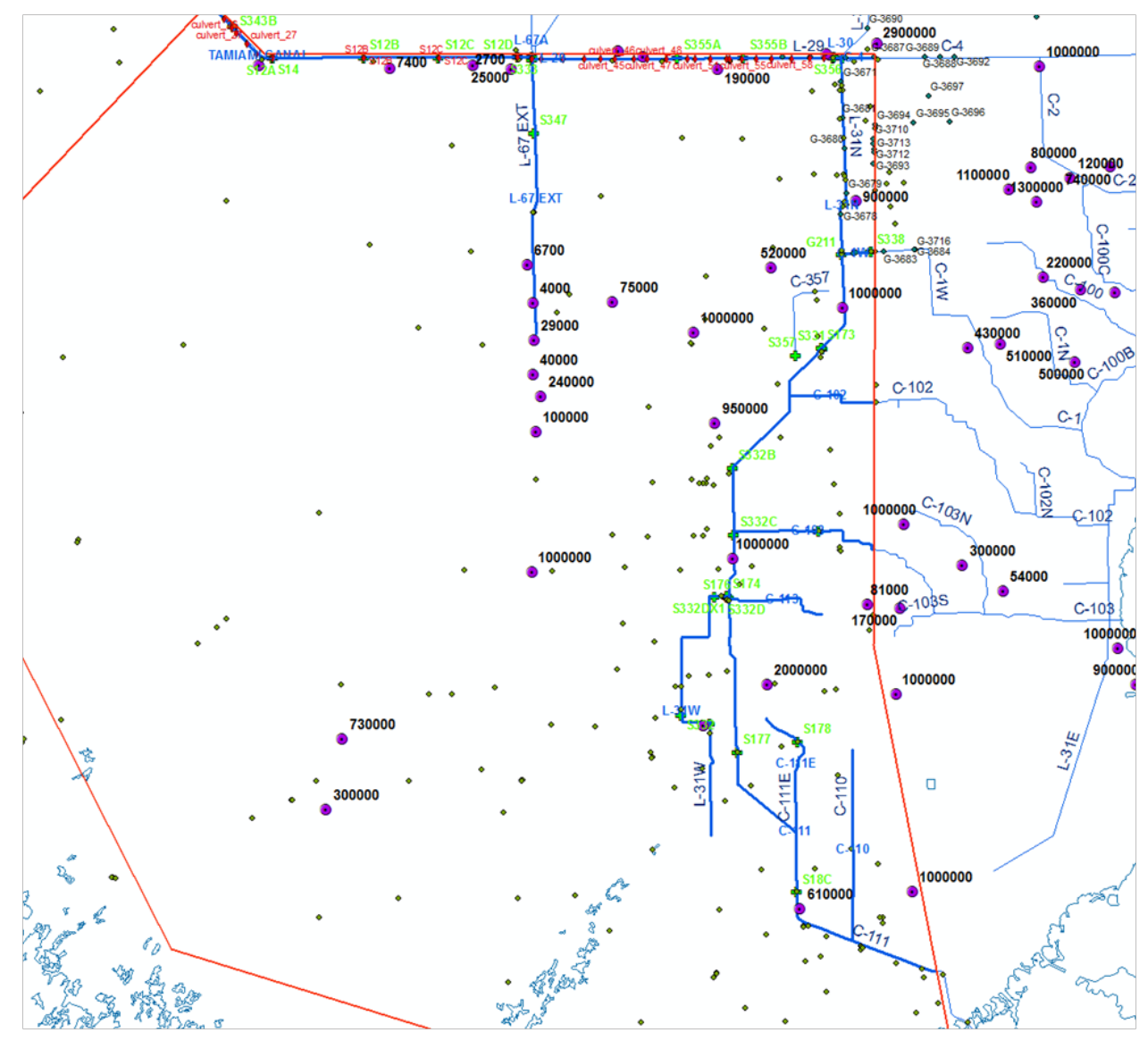

Figure 4.18: Location of pump tests used to generate the transmissivity of the SAS [9] 


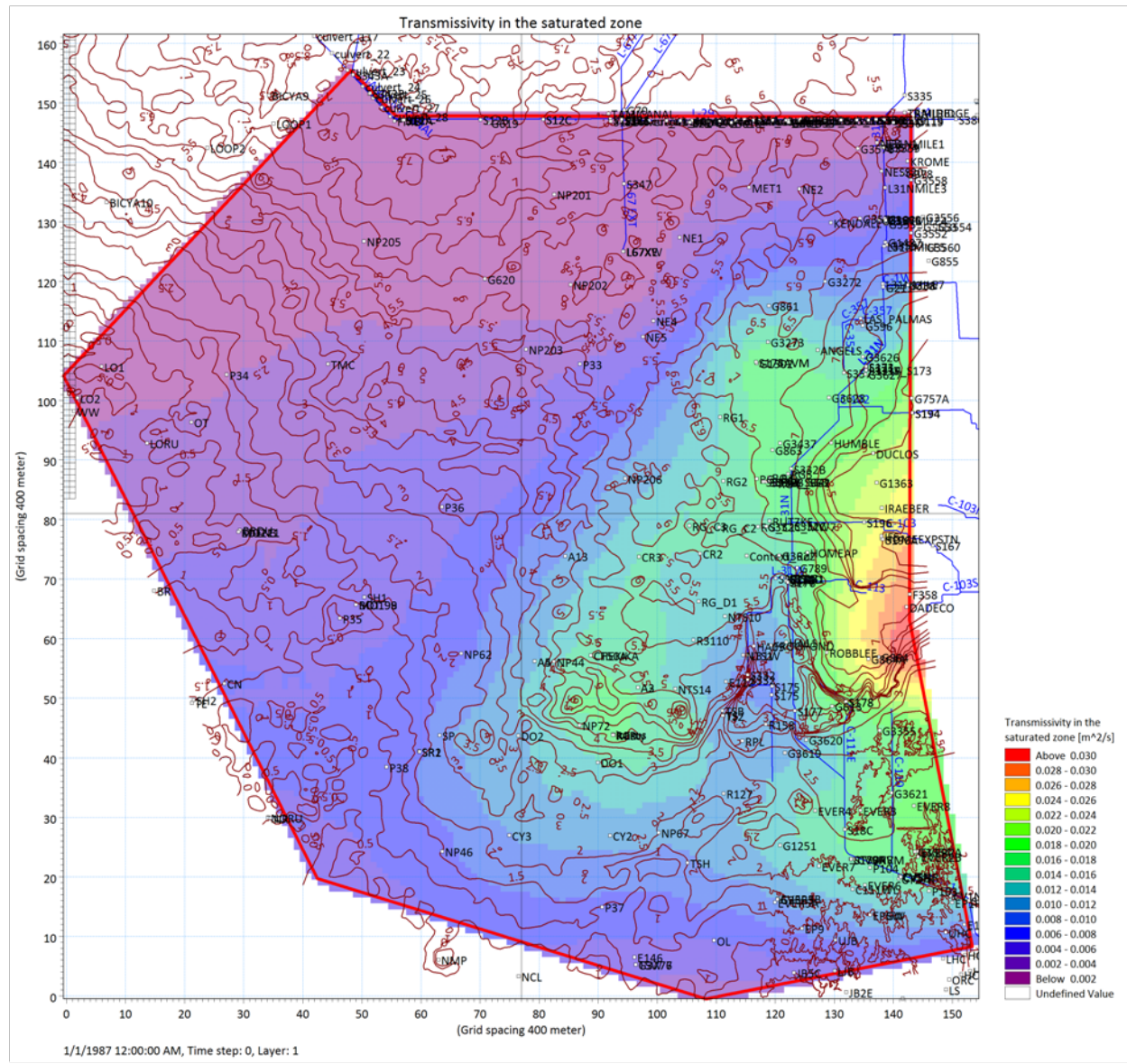

Figure 4.19: Transmissivity of layer 1-Miami Oolite 


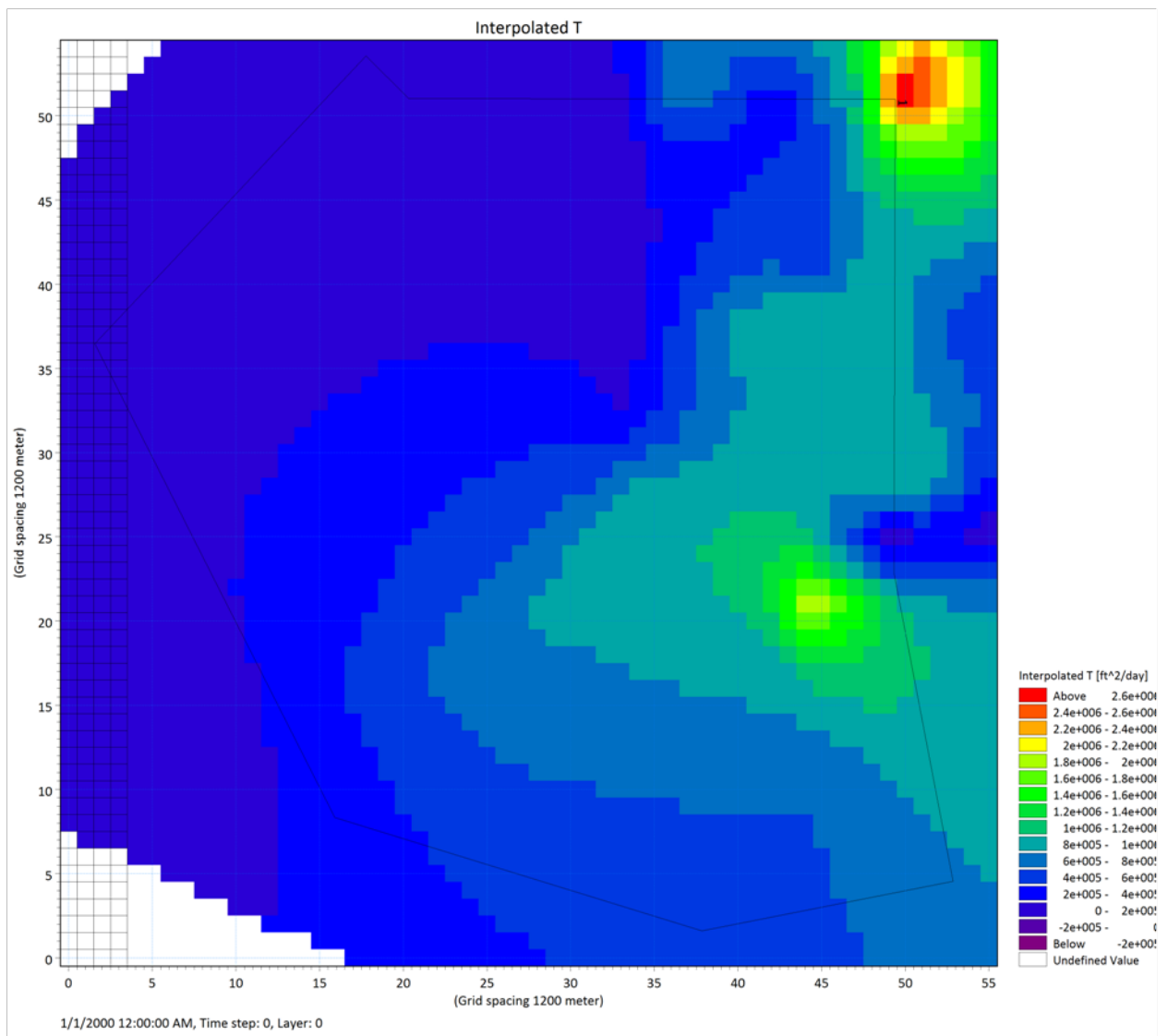

Figure 4.20: Interpolated transmissivity data for Layer 2-SAS (up to 2,000,000 $\mathrm{ft} /$ day) 


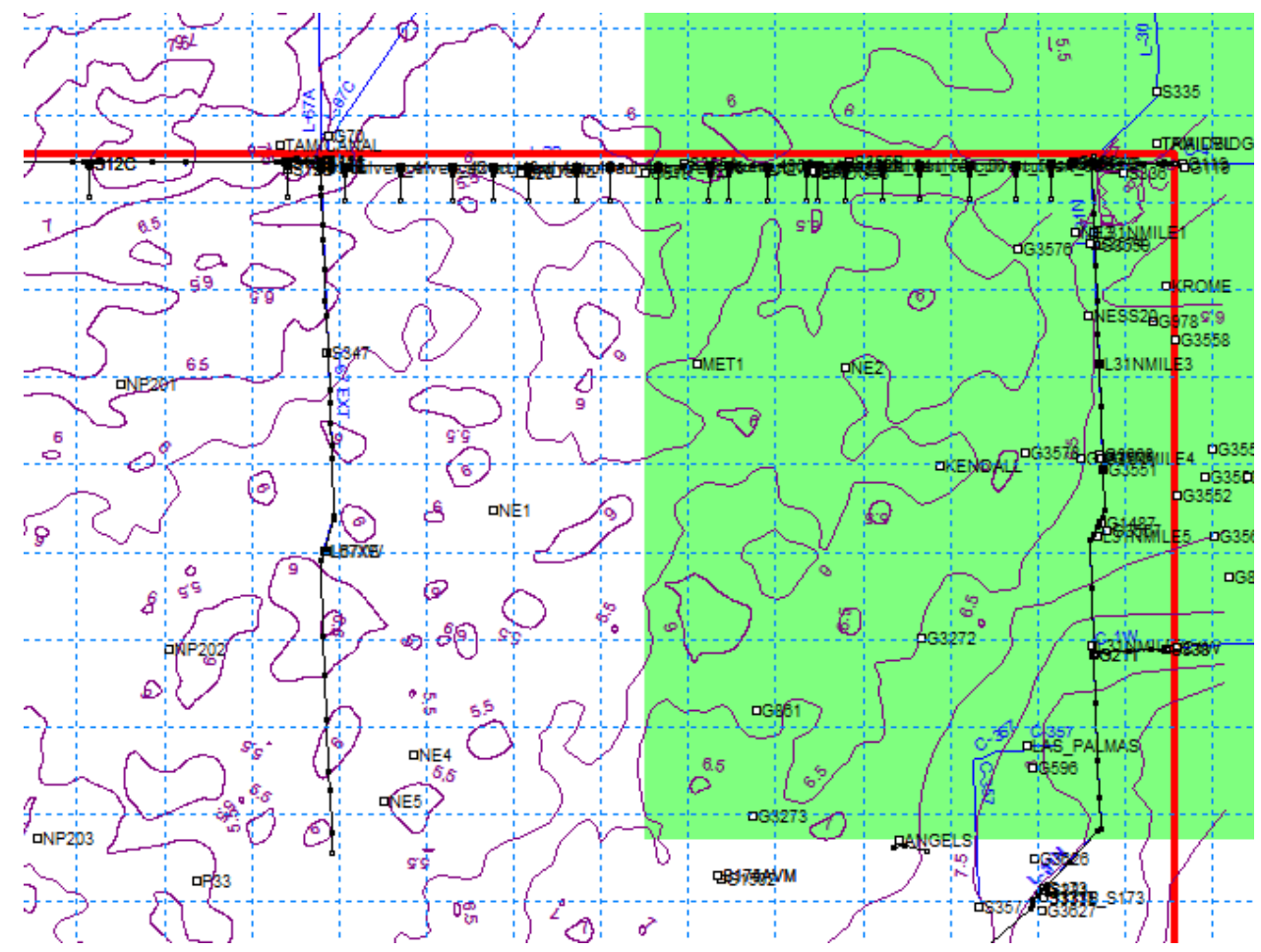

Figure 4.21: Geological lens layer Q5, implemented in the model as a one-foot lens with low conductivity 


\subsubsection{Boundary conditions}

Overland boundary conditions: No overland boundary conditions were used in the model. In general, the outer boundary condition for the overland flow solver is a specified head, based on the initial water depth in the outer nodes of the model domain. Thus, if the water depth inside the model domain is greater than the initial depth on the boundary, water will flow out of the model. If the water depth is less than the initial depth on the boundary, the boundary will act as a source of water.

Subsurface boundary conditions: Based on the hydrologic conditions, the subsurface boundaries were divided by zero flux, prescribed head time series, and prescribed gradients. Prescribed daily heads were determined from interpolating the water levels from adjacent stations for the simulation period. To determine the effect of the boundary conditions on the south and south east boundary (where limited data sets are available), a set of three simulations were conducted using different combinations of subsurface boundary conditions. Based on the model response, the following boundary conditions where used for model development:

- Prescribed head on the north boundary between S343A and S12A, using the tail water levels of S12A, S12B, S12C, and S12D

- Prescribed head along L-29 using the daily time series of L-29 water levels

- Prescribed head on the east boundary

- Prescribed head on the south and southwest section using $0 \mathrm{ft}$ head

- Zero flux on the west section of the domain where there is a natural hydrological divide

Daily observations from approximately 300 stage monitoring stations were used to create a gridded time series of the daily groundwater levels. The gridded data 
were then implemented for the boundary conditions along the domain perimeter. The same boundary conditions were prescribed for layer $1(\mathrm{Qm})$ and Layer 2 (SAS). As previously described, both layers are defined by the reduced conductivity of layer 2; however, there is no aquiclude between the two layers [9] and it is reasonable to assume that both layers are hydraulically connected for the entire domain.

Figure 4.22 shows the model domain along with the prescribed boundary conditions.

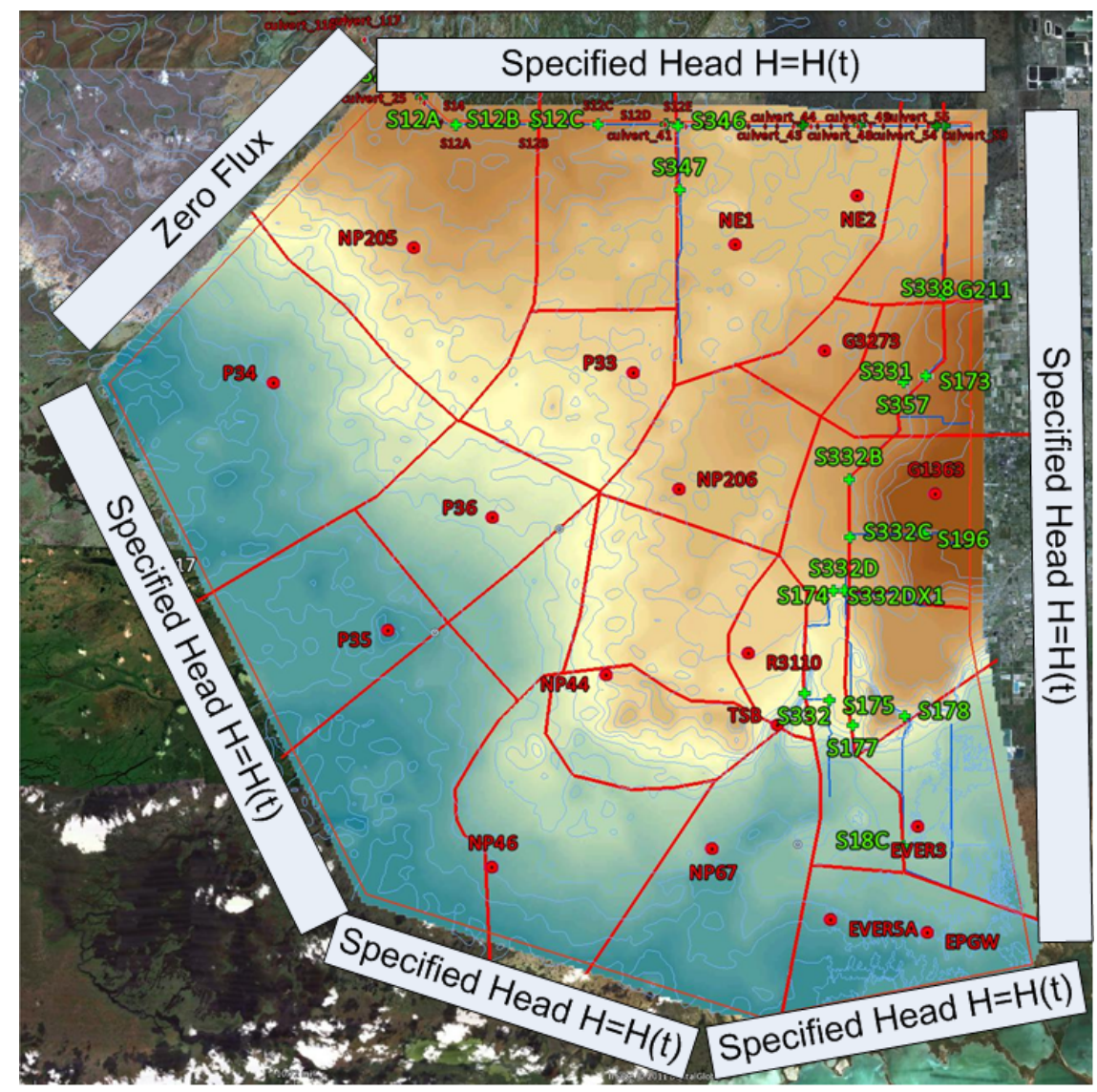

Figure 4.22: Prescribed subsurface boundary conditions 


\subsection{Model Calibration (1987-1997) and Validation (1998-2005)}

For model calibration, initial simulations were conducted to ensure that the model could successfully simulate the entire time period. If the model did not complete simulations, the model was examined to determine instabilities. Once the instabilities were corrected and the model completed simulations for the entire time period, simulations were completed for the model subdomains. These simulations used head boundary conditions for the saturated flow. Sixteen subdomains (including the entire MIKE 11 network) were used to determine the hydraulic conductivity and Manning's number for the subdomains, which provide the best fit of the time series and probability of exceedance. The initial simulations used prescribed internal boundary conditions for the MIKE 11 canals to reduce the number of calibration variables and focus on the parameters in MIKE SHE.

After determining best parameters for the subdomains, simulations for the entire domain provided information about model performance. Additional optimization of the model parameters was applied to improve the response of the model. After accomplishing a good response for the stages within the model domain, the internal boundary conditions in MIKE 11 were removed and structure operations were implemented. This resulted in the need for additional adjustment, mostly of the saturated conditions in the proximity of canals.

Once a satisfactory response was accomplished, a series of simulations varying the parameters shown in the green boxes of Figure 4.23 were completed. For data analysis, a series of MATLAB scripts were developed which were executed sequentially and provided an integrated analysis of observed and computed data from multiple simulations. The MATLAB script computed common statistical param-

eters and probability of exceedances provided a series of spatial maps which were 
used to determine the best approach for model calibration. Figure 4.23 shows the overall strategy for model calibration.

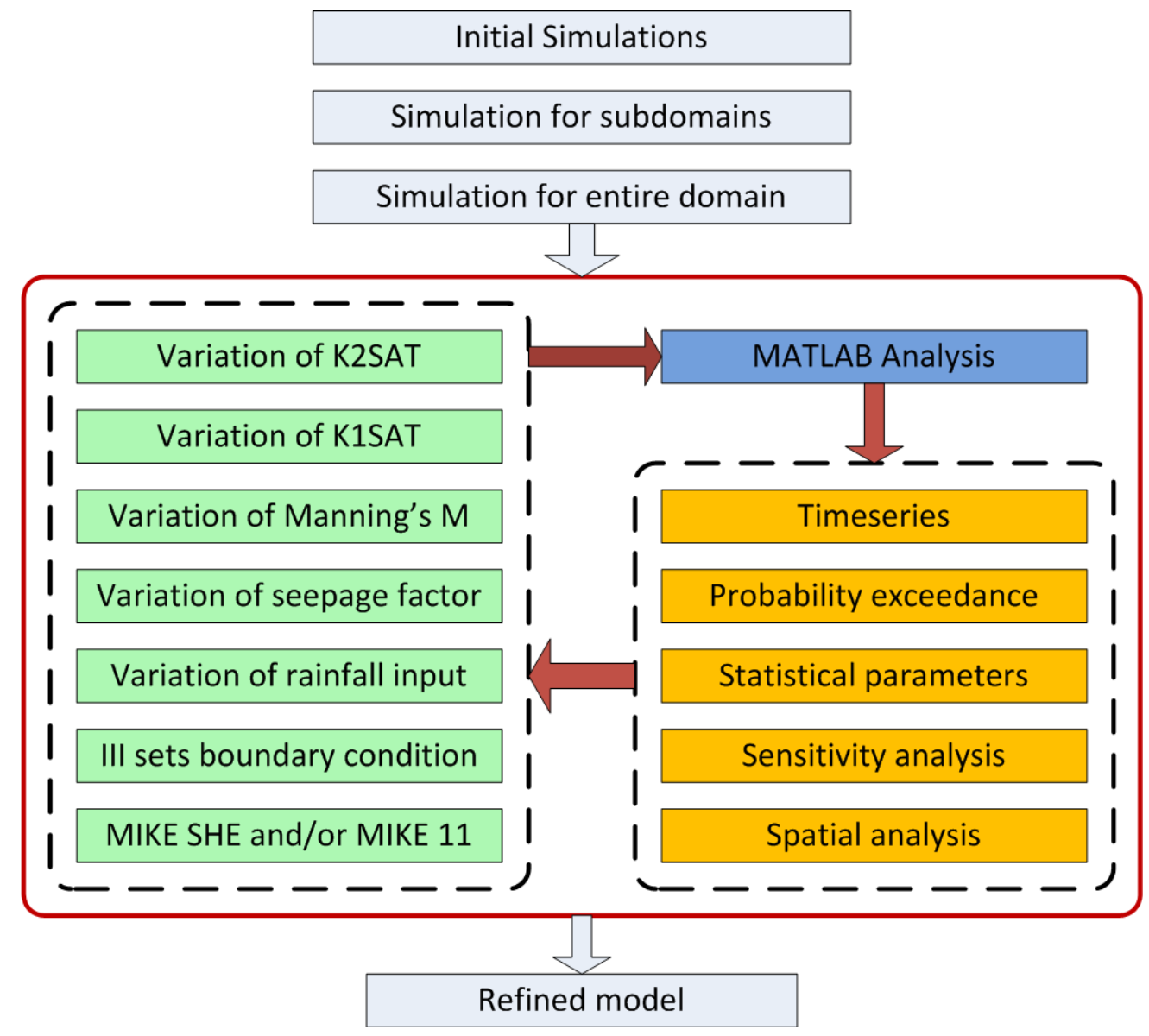

Figure 4.23: Flow chart of model calibration 
In sum, calibration simulations with the coupled model were conducted for the historical period of 1987-1997. Development of the model and calibration included:

- Development of the domain hydrogeology using two subsurface layers to represent the SAS. Published data for transmissivity was used to derive the hydraulic conductivity of each for the layers:

- Layer 1 represents the Qm geologic formation

- Layer 2 represents the zone from the bottom of the Qm to the bottom of the SAS

- Using a detailed map of the UZ to provide a better resolution of the subsurface. Calibration was performed by varying the van Genuchten parameters and the hydraulic conductivities.

- Using simplified vegetation and soil coverage, based on the parameter similarity, to improve the ET parameters, the overall response of the model, and the simulation run times.

- Using Manning's M, leakage coefficient, and horizontal conductivity of SAS to calibrate the model.

Using the optimized model parameters, the simulation period was extended to include the period for 1998-2005. Simulations with and without the detention areas were ran to determine the model performance for this period and to determine the effect on hydrology when detention areas are added to the model. Exploratory analysis, statistical analysis, and probability of exceedance were used to compare observed and computed data. 


\subsubsection{Manning's number}

Six simulations were completed by varying the Mannning's number by the following factors: $0.25,0.50,0.75,1.25,1.50,2.00$. After analyzing the resulting time series, an "optimized" manning's number (0.75 of the original) was determined. A set of seven simulations varying the "optimized" manning's coefficient by a factor of 0.25 , $0.50,0.75,1.25,1.50,1.75$, and 2.00 was completed for model validation.

\subsubsection{Conductivity of the Surficial Aquifer System}

Using the "optimized" Manning's number, the conductivity of the SAS was varied by a factor of $0.25,0.50,0.75,1.25,1.50,2.00$, and 4.00 in seven simulations. Adjustments to each subdomain were made based on exploratory analysis and the statistical analysis for each monitoring station.

\subsubsection{Leakage factor}

The leakage factor was varied in five simulations. The leakage factors for the simulations were $0.00005,0.0002,0.0001,0.001$, and 0.005 , respectively. The leakage factor had the greatest impact in cells with and adjacent to canals.

\subsection{Assumptions and Limitations}

The water stages across the entire domain are considerably accurate; however, additional adjustments would be required to provide a better representation with respect to local extremes (minimum and maximum stages). While the cyclic patterns of the water stages are well represented, there are some stage monitoring stations which follow the same pattern of the observed data, but do not match, this is possibly due to errors in the land elevations or errors within the monitoring station. In 
addition, some monitoring stations have limited data available due to the time of their construction, temporary mechanical malfunction, or destruction due to natural elements such as high winds.

The model resolution is also limitation. The model was developed with a $400 \mathrm{~m}$ resolution. While better than other models developed up to date, this still limits the level of detail the model can provide in some areas due to the dramatic changes in vegetation that found within a small area in ENP. In addition, there is observed data at discrete points within the domain, but it is assumed that the data is close to uniform within each $400 \mathrm{~m}$ cell. The Manning's M, conductivity of the SZ, soil and vegetation, and rainfall parameters are interpolated over the domain and simplified to minimize computational power and model run times. This interpolation is assumed to be accurate enough for the main objective of studying the areas hydrology and future restoration scenarios.

A large assumption made in the development of the model is the accuracy of published operation schedules of pumps and gates. The model operates based on the schedules printed by the USACOE [7] and SFWMD [6]. The majority of pumps and stations within the model domain are operated manually, or remotely by the USACOE Jacksonville office, and do not necessarily follow the operation schedule in an automated fashion as the pumps in the MIKE SHE/MIKE 11 model do. In addition, the opening and closing of gates in the MIKE SHE/MIKE 11 model is limited by the model time steps and gates take longer to open and close than in reality. Another limitation of the model is the lack of predictability for rainfall, as with any forecasting tool, therefore there is a limitation in the accuracy of predictions for future water levels and flows. 


\section{CHAPTER 5 \\ RESULTS AND DISCUSSION}

The model output was analyzed using the following approach:

1. Exploratory data analysis: Visual observation of observed and computed time series.

2. Analysis of statistical parameters: A number of statistical parameters were determined for the observed and computed time series.

3. Flow and stage duration curves Flow and stage duration curves were used to determine the model performance for time series with observed data. About 20 spatially distributed stage monitoring stations with accurate data were used to make model adjustments. Five key operating structures along L-31N and C-111 canals were also used in the model calibration.

4. Cumulative discharges Cumulative discharges from computed and observed data were used to investigate the water balance of the model.

Each simulation generates approximately 46 GB (for the period of 1987-2005) including the following time series of observed and computed data:

1. MIKE 11110 time series of daily discharge, headwater and tail water

2. MIKE SHE 170 time series of daily stages within model domain

3. Grid files 40 gridded data time series (subsurface and surface spatial hydrological quantities)

The data are accessible using a MATLAB toolbox provided by DHI and extended using few thousand lines of MATLAB code. 


\subsection{Exploratory Data Analysis}

For the purpose of exploratory data analysis, time series of computed and observed data were plotted on three representative figures for stage, discharge, and accumulated discharge. The figures were used to determine the effect of Manning's roughness coefficient on stage (Figure 5.1), discharge (Figure 5.2), and accumulated discharge (Figure 5.3). Figure 5.1-Figure 5.3 were used for the calibration period of 1987 through 1997. The same analysis was completed for each monitoring station within the domain. Similar figures were also generated for model validation for the time period of 1987 through 2005.

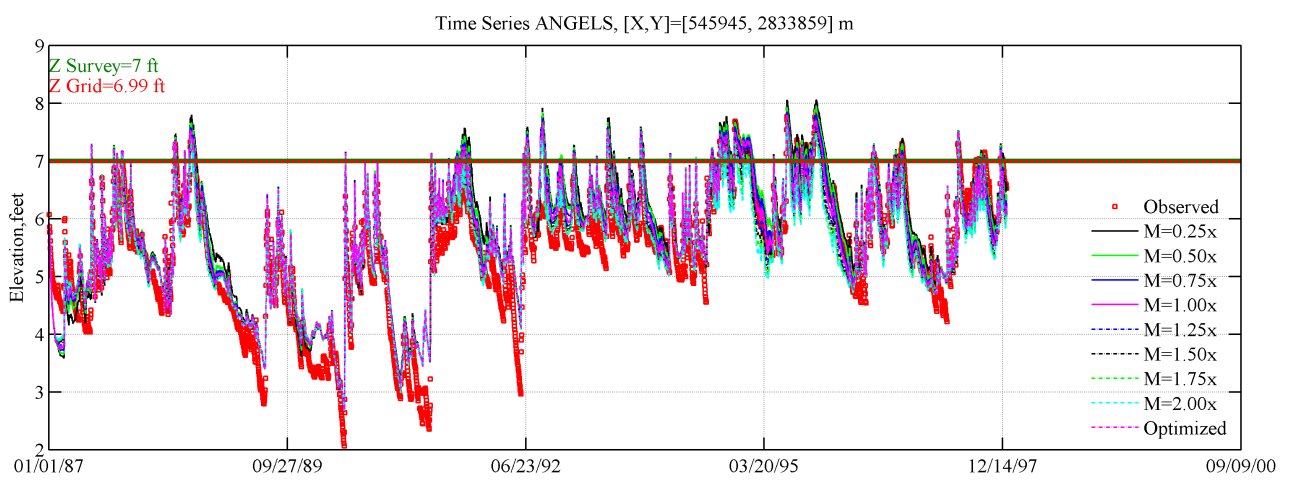

Figure 5.1: Example of stage time series for observed and computed data used to explore the general trends of model response with respect to hydrological events and the effect of different parameters on model response. The computed time series refer to a series of simulations which varied Manning's number, M to determine the best value in the vicinity of Angel's Well 


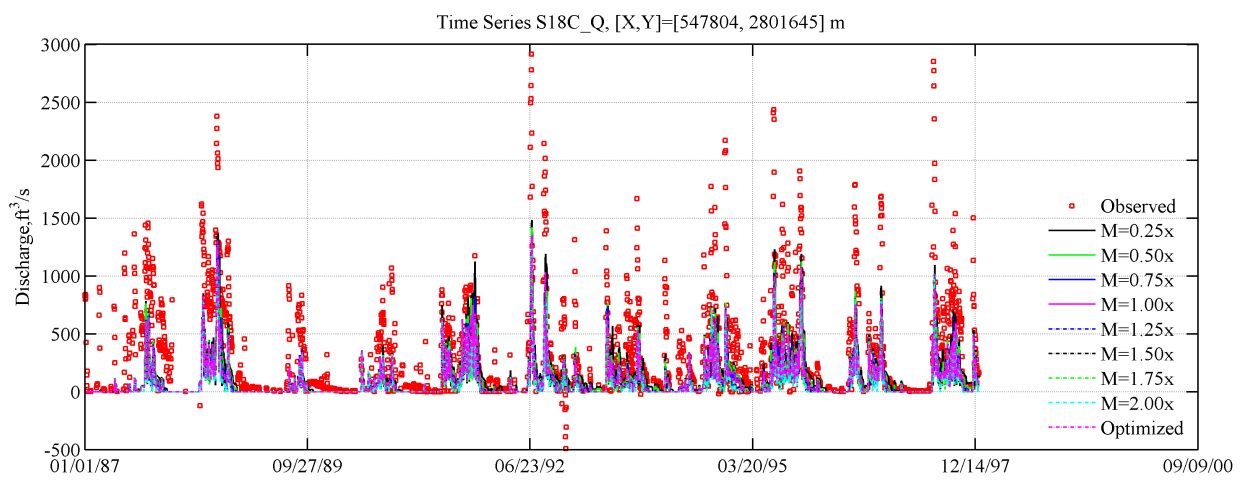

Figure 5.2: Example of discharge time series for observed and computed data, which provides information about the general trends of discharge through the structure. The time series response was used to modify and adjust structure operation rules

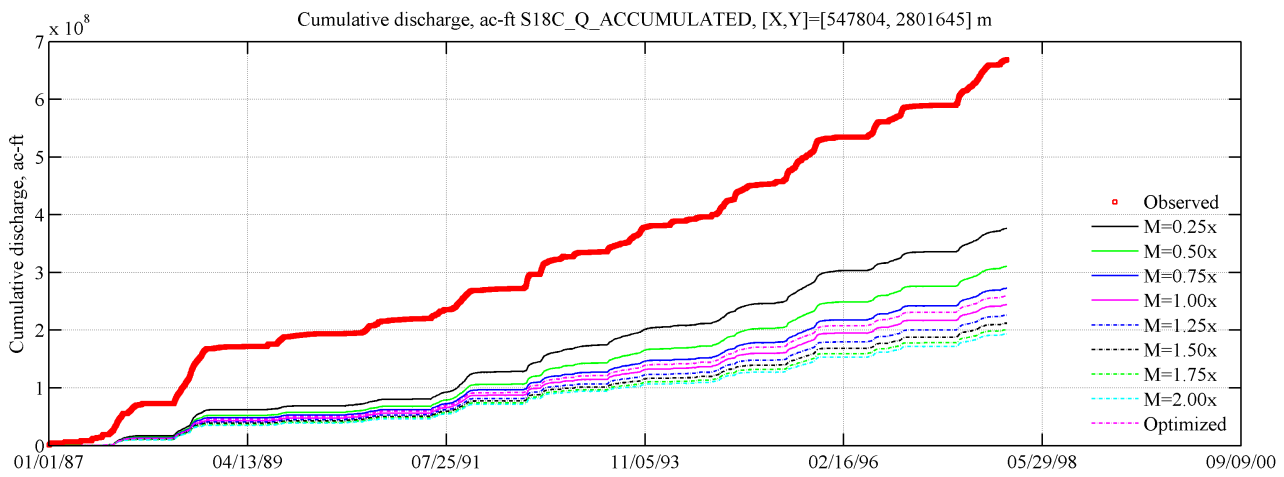

Figure 5.3: Example of accumulated discharges at structure S18C. The comparison was used to determine how the Manning's number, M impacts the discharge through the structure 


\subsection{Statistical Parameters}

For each simulation, and for each monitoring station with observed data, a set of statistical parameters was calculated, including:

1. ME: mean error equal to the sum of the difference of observed minus calculated, divided by the total number of samples

2. MAE: sum of the absolute difference of observed minus calculated, divided by the total number of samples

3. RMSE: root mean square of the observed minus computed

4. STD: standard deviation of the residual

5. NS: fraction of the error relative to the measured fluctuation

6. COVAR: standard deviation of the residual

7. COR: covariance of the observed and computed stage, divided by the product of the standard deviations

8. PEV: a measure of how two variables change with respect to each other, provided as a fraction rather than a percent

The results were summarized in tables and in figures generated by MATLAB and grouped by i) subdomain, ii) station, and iii) model run. For example, Table 5.1 provides the statistical parameters for stations in the vicinity of G3273 for simulations varying the Manning number. In this case, the table includes two wells. The first column in Table 5.1 lists the station, the second column lists the model run identifier $(\mathrm{M}=0.25 \mathrm{x}$, for example, refers to using a grid series that is one-quarter of the Manning value). The third column provides the number of data pairs, N, (observed and computed) which were used to determine the statistical parameters. 
Table 5.1: Statistical parameters for stations in the vicinity of G3273

\begin{tabular}{|c|c|c|c|c|c|c|c|c|c|c|}
\hline Station & Model Run & $\mathbf{N}$ & MA & MAE & RMSE & STD & NS & COVAR & COR & PEV \\
\hline \multirow[t]{9}{*}{ G3273 } & $\mathrm{M}=0.25 \mathrm{x}$ & 3514 & 0.48 & 0.55 & 0.01 & 0.01 & 0.69 & 1.22 & 0.94 & 0.88 \\
\hline & $\mathrm{M}=0.50 \mathrm{x}$ & 3514 & 0.38 & 0.44 & 0.01 & 0.01 & 0.79 & 1.16 & 0.95 & 0.90 \\
\hline & $M=0.75 x$ & 3514 & 0.30 & 0.36 & 0.01 & 0.01 & 0.83 & 1.10 & 0.95 & 0.90 \\
\hline & $\mathrm{M}=1.00 \mathrm{x}$ & 3514 & 0.24 & 0.34 & 0.01 & 0.01 & 0.85 & 1.07 & 0.95 & 0.90 \\
\hline & $\mathrm{M}=1.25 \mathrm{x}$ & 3514 & 0.19 & 0.33 & 0.01 & 0.01 & 0.86 & 1.03 & 0.94 & 0.89 \\
\hline & $\mathrm{M}=1.50 \mathrm{x}$ & 3514 & 0.15 & 0.33 & 0.01 & 0.01 & 0.86 & 1.01 & 0.94 & 0.88 \\
\hline & $M=1.75 \mathrm{x}$ & 3514 & 0.12 & 0.34 & 0.01 & 0.01 & 0.85 & 0.99 & 0.93 & 0.87 \\
\hline & $\mathrm{M}=2.00 \mathrm{x}$ & 3514 & 0.09 & 0.34 & 0.01 & 0.01 & 0.85 & 0.97 & 0.93 & 0.86 \\
\hline & Optimized & 3514 & 0.24 & 0.34 & 0.01 & 0.01 & 0.85 & 1.07 & 0.95 & 0.90 \\
\hline \multirow[t]{9}{*}{ G1502 } & $\mathrm{M}=0.25 \mathrm{x}$ & 3867 & 0.33 & 0.43 & 0.01 & 0.01 & 0.81 & 1.42 & 0.95 & 0.89 \\
\hline & $\mathrm{M}=0.50 \mathrm{x}$ & 3867 & 0.23 & 0.34 & 0.01 & 0.01 & 0.87 & 1.36 & 0.95 & 0.91 \\
\hline & $M=0.75 x$ & 3867 & 0.16 & 0.31 & 0.01 & 0.01 & 0.89 & 1.30 & 0.95 & 0.90 \\
\hline & $\mathrm{M}=1.00 \mathrm{x}$ & 3867 & 0.10 & 0.31 & 0.01 & 0.01 & 0.89 & 1.26 & 0.95 & 0.89 \\
\hline & $\mathrm{M}=1.25 \mathrm{x}$ & 3867 & 0.05 & 0.32 & 0.01 & 0.01 & 0.88 & 1.22 & 0.94 & 0.88 \\
\hline & $\mathrm{M}=1.50 \mathrm{x}$ & 3867 & 0.01 & 0.33 & 0.01 & 0.01 & 0.87 & 1.19 & 0.94 & 0.87 \\
\hline & $M=1.75 \mathrm{x}$ & 3867 & -0.02 & 0.34 & 0.01 & 0.01 & 0.86 & 1.16 & 0.93 & 0.86 \\
\hline & $\mathrm{M}=2.00 \mathrm{x}$ & 3867 & -0.05 & 0.36 & 0.01 & 0.01 & 0.85 & 1.14 & 0.93 & 0.85 \\
\hline & Optimized & 3867 & 0.10 & 0.31 & 0.01 & 0.01 & 0.89 & 1.26 & 0.95 & 0.90 \\
\hline
\end{tabular}

The scripts calculate the statistical parameters only when there are pairs of data (observed vs. computed). Similar tables were produced for more than 160 stations within the domain (including MIKE 11 flows and stages and MIKE SHE stages). 


\subsection{Probability of Exceedance}

In addition to listing the statistical parameters, the probability of exceedance was calculated for each station and displayed. Selected exceedance values $(0.01,0.05$, $0.10,0.20,0.50,0.80,0.90,0.95$ and 0.99 ) were extracted and explored in both table and chart format. Figure 5.4 shows the stage probability of exceedance for station NE5 and Figure 5.5 shows the probability of exceedance for discharge though structure S18C. The figures provided information about the statistical response of the model for the entire range of the hydrological regime. Elevation is displayed on the y-axis with a horizontal green line across the graph representing the ground surface elevation at the station or structure. For the response above ground level at monitoring stations, parameters effecting the overland flow, such as Manning's M were varied. For the subsurface response, parameters such as the hydraulic conductivities or leekage factors were varied.

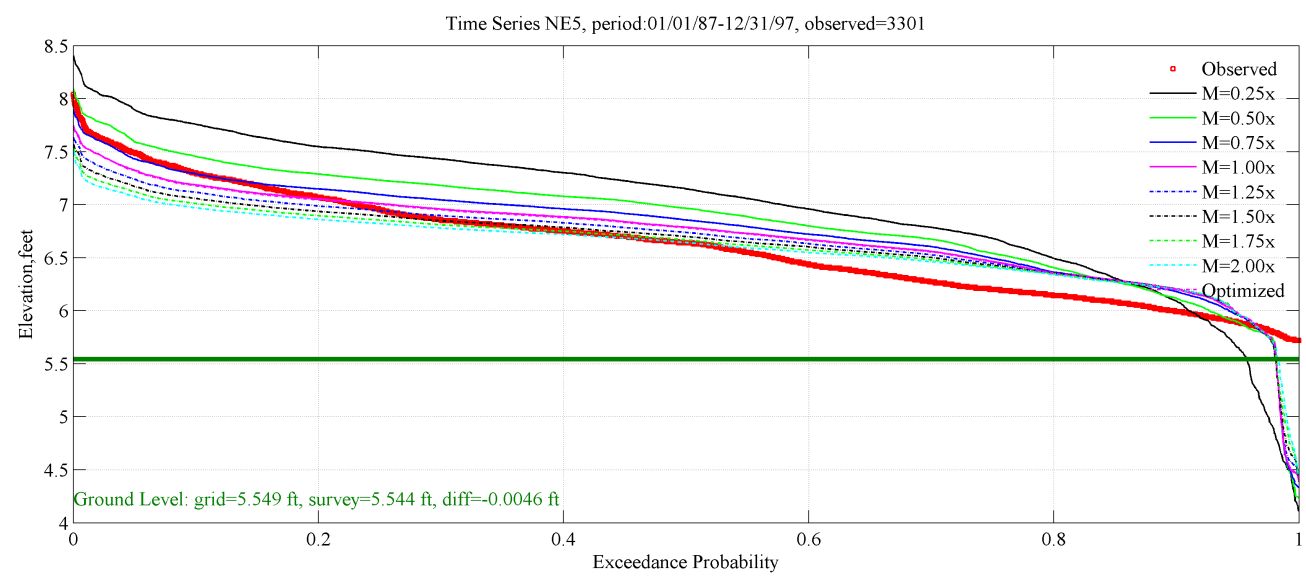

Figure 5.4: Example of stage exceedance probability ffor observed and computed data using monitoring station NE5

In addition, tables were extracted which showed the statistical difference between observed and computed data for the entire hydrological regime of the monitoring station. Table 5.2 shows an example of the exceedance probability for stations in 


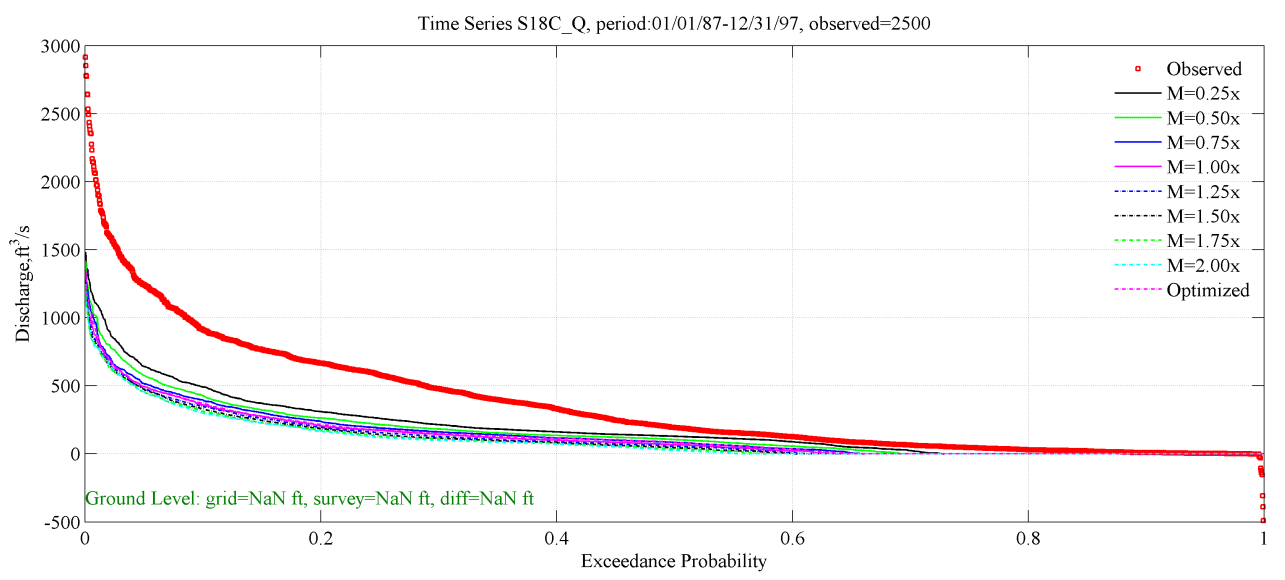

Figure 5.5: Example of exceedance probability for discharge through S18C

the vicinity of NE1. For this particular example, the adjustment of the Manning's number was made after simultaneous review and investigation of the time series, exceedance probability curves, and probability of exceedance tables for the difference of observed versus computed. 
Table 5.2: Exceedance probability for stations in the vicinity of NE1

\begin{tabular}{|c|c|c|c|c|c|c|c|c|c|c|}
\hline \multirow[b]{2}{*}{ Station } & \multirow[b]{2}{*}{ Model Run } & \multicolumn{9}{|c|}{ Exceedance Probability (Observed - Computed) } \\
\hline & & 0.01 & 0.05 & 0.10 & 0.20 & 0.50 & 0.80 & 0.90 & 0.95 & 0.99 \\
\hline \multirow[t]{9}{*}{ NE2 } & $\mathrm{M}=0.25 \mathrm{x}$ & 1.07 & 0.82 & 0.74 & 0.63 & 0.41 & 0.30 & 0.20 & -0.05 & -0.89 \\
\hline & $\mathrm{M}=0.50 \mathrm{x}$ & 1.07 & 0.64 & 0.55 & 0.47 & 0.24 & 0.13 & 0.06 & -0.05 & -0.82 \\
\hline & $\mathrm{M}=0.75 \mathrm{x}$ & 1.03 & 0.59 & 0.47 & 0.35 & 0.16 & 0.00 & -0.07 & -0.11 & -0.79 \\
\hline & $\mathrm{M}=1.00 \mathrm{x}$ & 1.02 & 0.59 & 0.43 & 0.28 & 0.09 & -0.08 & -0.16 & -0.20 & -0.76 \\
\hline & $\mathrm{M}=1.25 \mathrm{x}$ & 1.01 & 0.57 & 0.39 & 0.24 & 0.04 & -0.15 & -0.22 & -0.28 & -0.75 \\
\hline & $\mathrm{M}=1.50 \mathrm{x}$ & 1.01 & 0.56 & 0.37 & 0.21 & 0.01 & -0.20 & -0.28 & -0.35 & -0.75 \\
\hline & $\mathrm{M}=1.75 \mathrm{x}$ & 1.00 & 0.54 & 0.35 & 0.19 & -0.02 & -0.25 & -0.32 & -0.39 & -0.74 \\
\hline & $\mathrm{M}=2.00 \mathrm{x}$ & 1.00 & 0.53 & 0.33 & 0.18 & -0.04 & -0.28 & -0.36 & -0.43 & -0.75 \\
\hline & Optimized & 0.99 & 0.57 & 0.43 & 0.28 & 0.10 & -0.08 & -0.15 & -0.19 & -0.78 \\
\hline \multirow[t]{9}{*}{ NE4 } & $\mathrm{M}=0.25 \mathrm{x}$ & 0.62 & 0.52 & 0.47 & 0.42 & 0.28 & -0.01 & -0.19 & -0.89 & -1.94 \\
\hline & $\mathrm{M}=0.50 \mathrm{x}$ & 0.51 & 0.31 & 0.24 & 0.18 & 0.06 & -0.13 & -0.26 & -0.40 & -1.96 \\
\hline & $M=0.75 x$ & 0.53 & 0.26 & 0.16 & 0.07 & -0.07 & -0.20 & -0.31 & -0.43 & -1.91 \\
\hline & $\mathrm{M}=1.00 \mathrm{x}$ & 0.58 & 0.24 & 0.13 & 0.00 & -0.15 & -0.28 & -0.36 & -0.49 & -1.81 \\
\hline & $\mathrm{M}=1.25 \mathrm{x}$ & 0.59 & 0.23 & 0.11 & -0.03 & -0.20 & -0.34 & -0.44 & -0.55 & -1.75 \\
\hline & $\mathrm{M}=1.50 \mathrm{x}$ & 0.61 & 0.23 & 0.10 & -0.06 & -0.24 & -0.39 & -0.50 & -0.59 & -1.66 \\
\hline & $\mathrm{M}=1.75 \mathrm{x}$ & 0.60 & 0.23 & 0.09 & -0.08 & -0.27 & -0.43 & -0.54 & -0.61 & -1.58 \\
\hline & $\mathrm{M}=2.00 \mathrm{x}$ & 0.59 & 0.23 & 0.08 & -0.10 & -0.30 & -0.47 & -0.58 & -0.65 & -1.52 \\
\hline & Optimized & 0.59 & 0.25 & 0.14 & 0.01 & -0.14 & -0.28 & -0.35 & -0.48 & -1.80 \\
\hline \multicolumn{11}{|c|}{ Continued on Next Page. } \\
\hline
\end{tabular}


Table 5.2-Continued

\begin{tabular}{|c|c|c|c|c|c|c|c|c|c|c|}
\hline Station & Model Run & 0.01 & 0.05 & 0.10 & 0.20 & 0.50 & 0.80 & 0.90 & 0.95 & 0.99 \\
\hline \multirow[t]{9}{*}{ NE5 } & $\mathrm{M}=0.25 \mathrm{x}$ & 0.89 & 0.82 & 0.74 & 0.64 & 0.43 & 0.28 & 0.09 & -0.47 & -1.55 \\
\hline & $\mathrm{M}=0.50 \mathrm{x}$ & 0.67 & 0.59 & 0.54 & 0.47 & 0.23 & 0.07 & 0.01 & -0.05 & -1.53 \\
\hline & $M=0.75 x$ & 0.63 & 0.51 & 0.45 & 0.39 & 0.18 & -0.04 & -0.13 & -0.19 & -1.52 \\
\hline & $\mathrm{M}=1.00 \mathrm{x}$ & 0.60 & 0.47 & 0.41 & 0.33 & 0.14 & -0.14 & -0.23 & -0.31 & -1.48 \\
\hline & $\mathrm{M}=1.25 \mathrm{x}$ & 0.57 & 0.45 & 0.38 & 0.30 & 0.11 & -0.22 & -0.31 & -0.40 & -1.43 \\
\hline & $\mathrm{M}=1.50 \mathrm{x}$ & 0.55 & 0.43 & 0.36 & 0.27 & 0.08 & -0.28 & -0.38 & -0.47 & -1.36 \\
\hline & $\mathrm{M}=1.75 \mathrm{x}$ & 0.54 & 0.41 & 0.35 & 0.25 & 0.06 & -0.32 & -0.44 & -0.53 & -1.28 \\
\hline & $\mathrm{M}=2.00 \mathrm{x}$ & 0.53 & 0.40 & 0.34 & 0.24 & 0.04 & -0.35 & -0.48 & -0.58 & -1.17 \\
\hline & Optimized & 0.59 & 0.47 & 0.40 & 0.32 & 0.13 & -0.14 & -0.23 & -0.31 & -1.48 \\
\hline \multirow[t]{9}{*}{ BRDG53 } & $\mathrm{M}=0.25 \mathrm{x}$ & 0.60 & 0.50 & 0.40 & 0.25 & 0.12 & -0.02 & -0.08 & -0.14 & -0.25 \\
\hline & $\mathrm{M}=0.50 \mathrm{x}$ & 0.37 & 0.23 & 0.15 & 0.08 & -0.04 & -0.16 & -0.23 & -0.28 & -0.35 \\
\hline & $M=0.75 x$ & 0.25 & 0.14 & 0.07 & -0.00 & -0.14 & -0.24 & -0.33 & -0.39 & -0.46 \\
\hline & $\mathrm{M}=1.00 \mathrm{x}$ & 0.20 & 0.11 & 0.04 & -0.05 & -0.21 & -0.32 & -0.40 & -0.46 & -0.54 \\
\hline & $\mathrm{M}=1.25 \mathrm{x}$ & 0.20 & 0.09 & 0.00 & -0.09 & -0.26 & -0.38 & -0.46 & -0.52 & -0.59 \\
\hline & $\mathrm{M}=1.50 \mathrm{x}$ & 0.20 & 0.07 & -0.01 & -0.11 & -0.30 & -0.43 & -0.50 & -0.56 & -0.63 \\
\hline & $\mathrm{M}=1.75 \mathrm{x}$ & 0.19 & 0.07 & -0.03 & -0.13 & -0.34 & -0.47 & -0.54 & -0.60 & -0.67 \\
\hline & $\mathrm{M}=2.00 \mathrm{x}$ & 0.19 & 0.07 & -0.04 & -0.15 & -0.36 & -0.50 & -0.58 & -0.63 & -0.70 \\
\hline & Optimized & 0.21 & 0.12 & 0.04 & -0.04 & -0.19 & -0.30 & -0.38 & -0.44 & -0.51 \\
\hline \multirow[t]{9}{*}{ L67XW } & $\mathrm{M}=0.25 \mathrm{x}$ & 2.23 & 1.74 & 1.64 & 1.49 & 0.86 & 0.38 & 0.17 & -0.01 & -0.79 \\
\hline & $\mathrm{M}=0.50 \mathrm{x}$ & 1.45 & 1.09 & 0.97 & 0.82 & 0.45 & 0.12 & 0.01 & -0.11 & -0.62 \\
\hline & $\mathrm{M}=0.75 \mathrm{x}$ & 1.00 & 0.76 & 0.59 & 0.45 & 0.18 & -0.02 & -0.09 & -0.21 & -0.47 \\
\hline & $\mathrm{M}=1.00 \mathrm{x}$ & 0.88 & 0.52 & 0.40 & 0.29 & 0.01 & -0.13 & -0.20 & -0.30 & -0.53 \\
\hline & $\mathrm{M}=1.25 \mathrm{x}$ & 0.85 & 0.41 & 0.30 & 0.18 & -0.08 & -0.26 & -0.33 & -0.39 & -0.60 \\
\hline & $\mathrm{M}=1.50 \mathrm{x}$ & 0.87 & 0.32 & 0.24 & 0.11 & -0.15 & -0.36 & -0.46 & -0.53 & -0.69 \\
\hline & $\mathrm{M}=1.75 \mathrm{x}$ & 0.85 & 0.27 & 0.19 & 0.06 & -0.20 & -0.45 & -0.56 & -0.65 & -0.76 \\
\hline & $\mathrm{M}=2.00 \mathrm{x}$ & 0.82 & 0.24 & 0.15 & 0.01 & -0.23 & -0.53 & -0.66 & -0.75 & -0.86 \\
\hline & Optimized & 0.88 & 0.52 & 0.41 & 0.29 & 0.01 & -0.13 & -0.20 & -0.29 & -0.51 \\
\hline
\end{tabular}

Continued on Next Page... 
Table 5.2 - Continued

\begin{tabular}{llllllllllll}
\hline \hline Station & Model Run & $\mathbf{0 . 0 1}$ & $\mathbf{0 . 0 5}$ & $\mathbf{0 . 1 0}$ & $\mathbf{0 . 2 0}$ & $\mathbf{0 . 5 0}$ & $\mathbf{0 . 8 0}$ & $\mathbf{0 . 9 0}$ & $\mathbf{0 . 9 5}$ & $\mathbf{0 . 9 9}$ \\
\hline \multirow{2}{*}{ L67XE } & $\mathrm{M}=0.25 \mathrm{x}$ & 2.66 & 2.46 & 2.25 & 2.00 & 0.95 & 0.32 & 0.10 & -0.16 & -1.17 \\
& $\mathrm{M}=0.50 \mathrm{x}$ & 2.07 & 1.85 & 1.51 & 1.25 & 0.62 & 0.11 & -0.05 & -0.30 & -1.17 \\
& $\mathrm{M}=0.75 \mathrm{x}$ & 1.66 & 1.38 & 1.11 & 0.88 & 0.43 & -0.01 & -0.13 & -0.38 & -1.16 \\
& $\mathrm{M}=1.00 \mathrm{x}$ & 1.30 & 1.05 & 0.89 & 0.65 & 0.31 & -0.09 & -0.22 & -0.42 & -1.19 \\
& $\mathrm{M}=1.25 \mathrm{x}$ & 1.06 & 0.86 & 0.71 & 0.51 & 0.22 & -0.15 & -0.27 & -0.44 & -1.18 \\
& $\mathrm{M}=1.50 \mathrm{x}$ & 0.91 & 0.72 & 0.56 & 0.41 & 0.13 & -0.20 & -0.31 & -0.46 & -1.19 \\
& $\mathrm{M}=1.75 \mathrm{x}$ & 0.90 & 0.61 & 0.46 & 0.33 & 0.06 & -0.24 & -0.35 & -0.47 & -1.17 \\
& $\mathrm{M}=2.00 \mathrm{x}$ & 0.89 & 0.52 & 0.39 & 0.27 & -0.01 & -0.28 & -0.39 & -0.48 & -1.18 \\
& & & & & & & & & & & \\
& Optimized & 1.32 & 1.05 & 0.88 & 0.65 & 0.32 & -0.09 & -0.21 & -0.40 & -1.16 \\
\hline
\end{tabular}

\subsection{Water Balance}

The water balance for a simulation including detention areas (DA) and the water balance for a simulation without the detention areas implemented (NDA) were analyzed. The water balance data calculated in MIKE SHE for the entire domain for a simulation with detention areas is displayed in Figure 5.6. The simulation period was from January 1, 1987 through December 31, 2005. The model error is shown in the upper left side of the figure. The error indicates convergence problems in the model, in both simulations the error was 0. Table 5.3 summarizes the categories of storage components and the difference in the storage depth for each hydrological component for both simulations. It is assumed that the simulation without the detention areas is a more accurate representation of the current hydrology in ENP since the detention areas includes all features of the future C111 project area. Simu- 
lations with the detention areas serve for forecasting the effect of future restoration projects on hydrology in ENP, after the USACOE completes the C111 project.

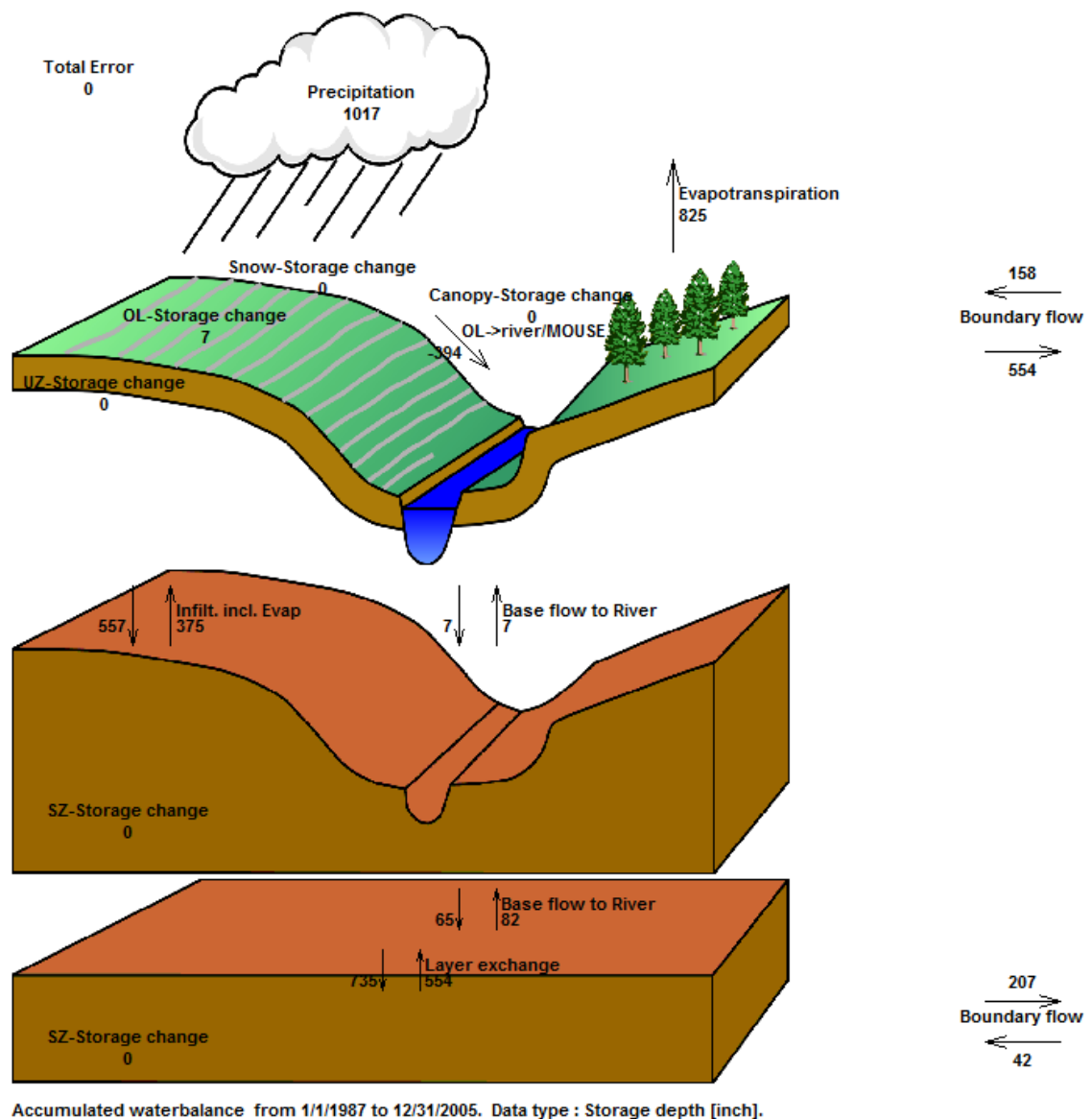

Figure 5.6: Water balance for the model with detention areas

From Figure 5.6, the greatest contribution of water entering the domain is from precipitation with a total of 1,017 inches over the 19 year simulation period. From Table 5.3 it can be seen that the greatest loss of water from the domain is in the form of evapotranspiration with an average of 826 inches for both simulations. This number is slightly lower than the average potential ET rate of $137 \mathrm{~cm}$ in ENP [31]. The greatest exchange of water takes place in the SZ, in the SAS. The total seepage from the canals is negligible and shows no overall change in the first layer of the SZ with the seepage to and from the canal being the same. Seepage from the SAS is 
more significant with an overall storage change of 62 inches from the canals and 82 inches seeping into the canals.

Table 5.3: Comparison of water storage data for simulations with no detention areas (NDA) and with detention areas implemented (DA). Storage depth measured in inches.

\begin{tabular}{lccc}
\hline Storage component & NDA, in & DA, in & Difference, in \\
\hline OL storage change & 7 & 7 & 0 \\
OL into canals & -394 & -392 & -2 \\
ET & 825 & 827 & -2 \\
Boundary flow into UZ & 158 & 162 & -4 \\
UZ flow out of the domain & 554 & 528 & 26 \\
Boundary flow into SZ & 42 & 52 & -10 \\
SZ flow out of the domain & 207 & 214 & -7 \\
UZ into SZ infiltration incl. evaporation & 557 & 618 & -61 \\
SZ infiltration to UZ incl. evaporation & 375 & 409 & -34 \\
SAS seepage into canals & 82 & 131 & -49 \\
Canal seepage into SAS & 65 & 84 & -19 \\
Miami Oolite seepage into canals & 7 & 10 & -3 \\
Canal seepage into Miami Oolite & 7 & 10 & -3 \\
SAS exchange to Miami Oolite & 554 & 586 & -30 \\
Miami Oolite exchange to SAS & 735 & 793 & -58 \\
\hline
\end{tabular}

\subsection{Sensitivity Analysis}

Sensitivity analysis was applied for selected output parameters (statistical parameters and probability of exceedance differences between observed and computed stage). The sensitivity analysis is available when at least two simulations are conducted which have modified input values. The sensitivity is computed as the first derivative of the model with respect to the hydrological quantity under consideration. For example, when the hydraulic conductivity of the SAS was modified in the vicinity of a selected station, the sensitivity was calculated as the first derivative of a given statistical parameter (either general parameters, such as Nash-Sutcliffe co- 


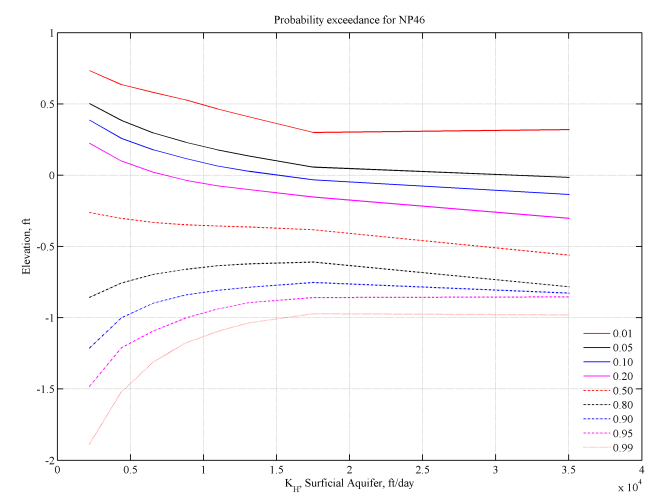

(a) NP46 Exceedance Probability

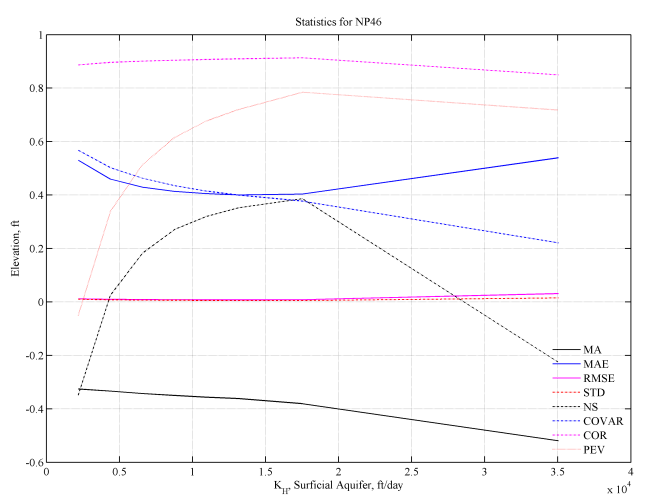

(b) NP46 Statistics

Figure 5.7: Sensitivity for hydraulic conductivity of the Surficial Aquifer System. Variations of probability exceedance and statistical parameters for observed and computed data at station NP46

efficient or selected exceedance probability, e.g. 0.05). Selected statistical variables were used to provide contour plots which display interpolated values of calculated statistical parameters, exceedance probability, and the corresponding sensitivity. Figure 5.7 provides the percent of exceedance and statistical analysis of the model for varied hydraulic conductivity in the SAS. The variations of the stage with respect to hydraulic conductivity were used to determine the sensitivity of the model in the vicinity of NP46. Figure 5.8 provides information about the sensitivity of the model for Manning's number. The figure shows that for increased Manning's number the simulations do not result in significant changes, i.e. model is not sensitive for Manning's values greater than 0.5 in the vicinity of NP46. 


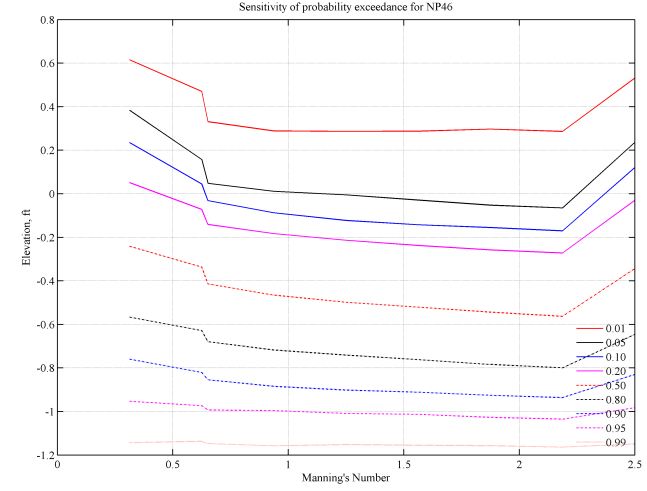

(a) Sensitivity of NP46 Exceedance Probability

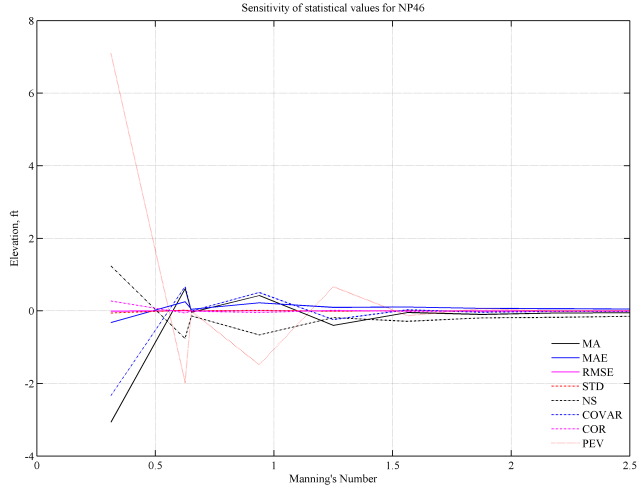

(b) Sensitivity of NP46 Statistics

Figure 5.8: Sensitivity of probability exceedance and statistical parameters for observed and computed data as function of the Manning's number at station NP46 


\subsection{Comparison with Other Models}

The computed water level data from stations common to the SFWMM and TIME were compared to the developed model. Monitoring stations were selected based on the availability of data and location. Stations with more than 70 percent of observed data available were considered for comparison. The comparisons are limited by data availability. The developed model includes the most recent topography and QA/QC'd data from ENP. This section displays the comparison for five selected stations representative for the basins within ENP: Western Marl Prairie, Shark Slough, Rocky Glades and Taylor Slough Basin.

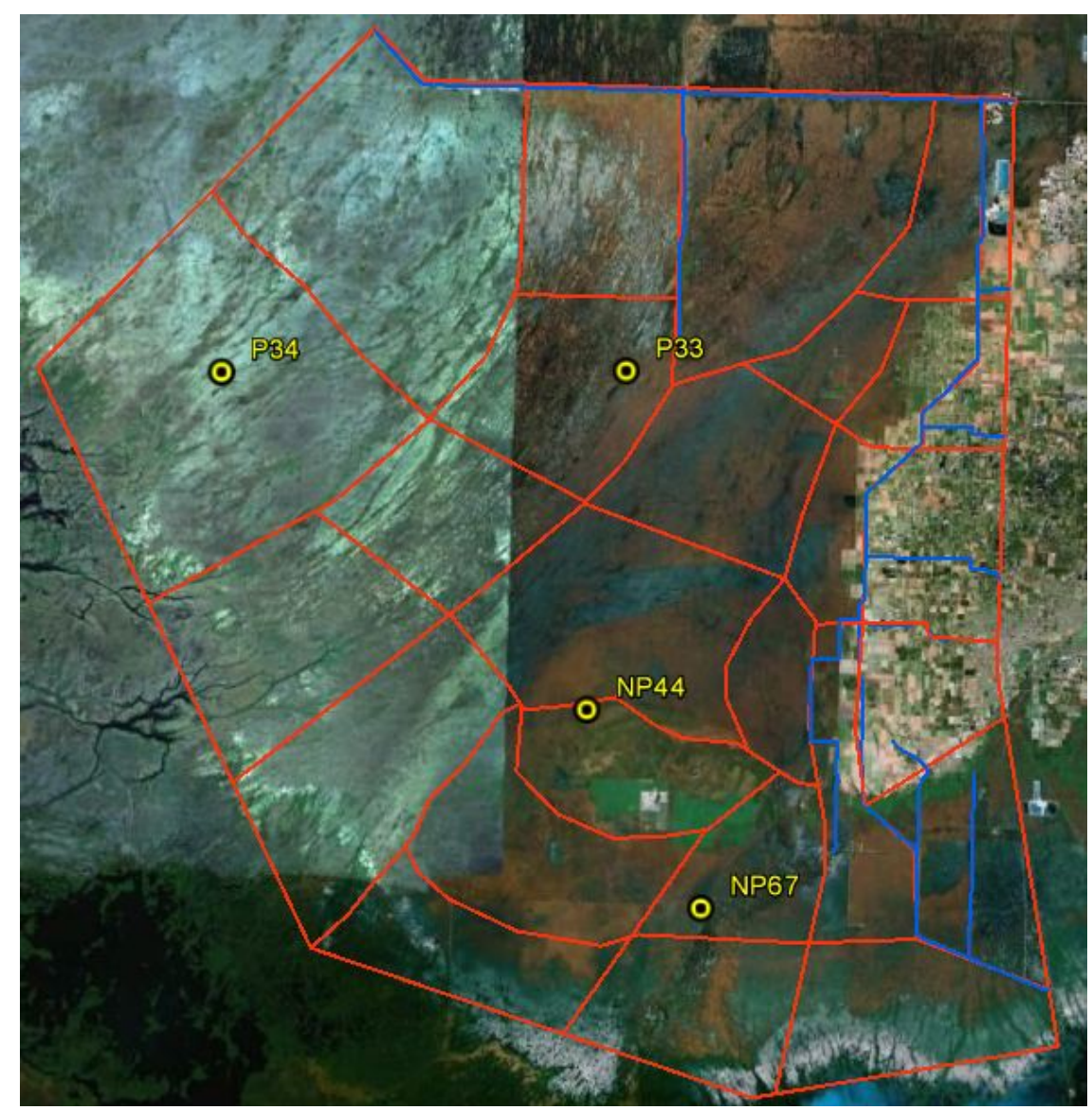

Figure 5.9: Location of stations used for comparison with other models 


\subsubsection{Western Marl Prairie}

This area is influenced by S12, S343A, and S343B discharges and contains some of the highest elevations in the Park. Station P34 was selected for comparison. Figure 5.10 shows the observed P34 time series and the computed time series from the SFWMM, TIME, and the developed model (M3ENP).

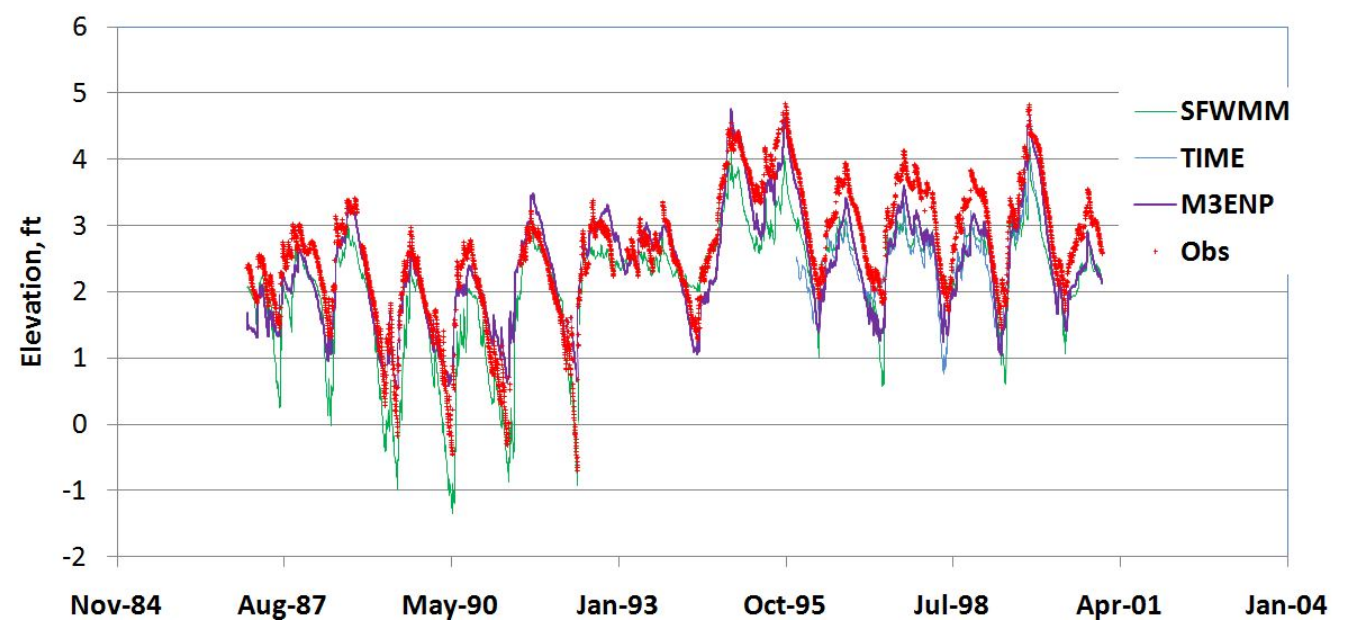

Figure 5.10: Comparison with other models: P34, Western Marl Prairie

\subsubsection{Shark Slough}

Water levels and flow are supplied by local rainfall and inflows through the Eastern Tamiami Trail culverts. Water in the Northeast Shark Slough is delivered through S333, which is generally kept closed when the water level at G3273 on the edge of the Rocky Glades reaches land surface. Water is distributed from S333 to Northeast Shark Slough via the L-29 borrow canal to the culverts. The central area of Shark Slough remains wet, except during drought periods. 


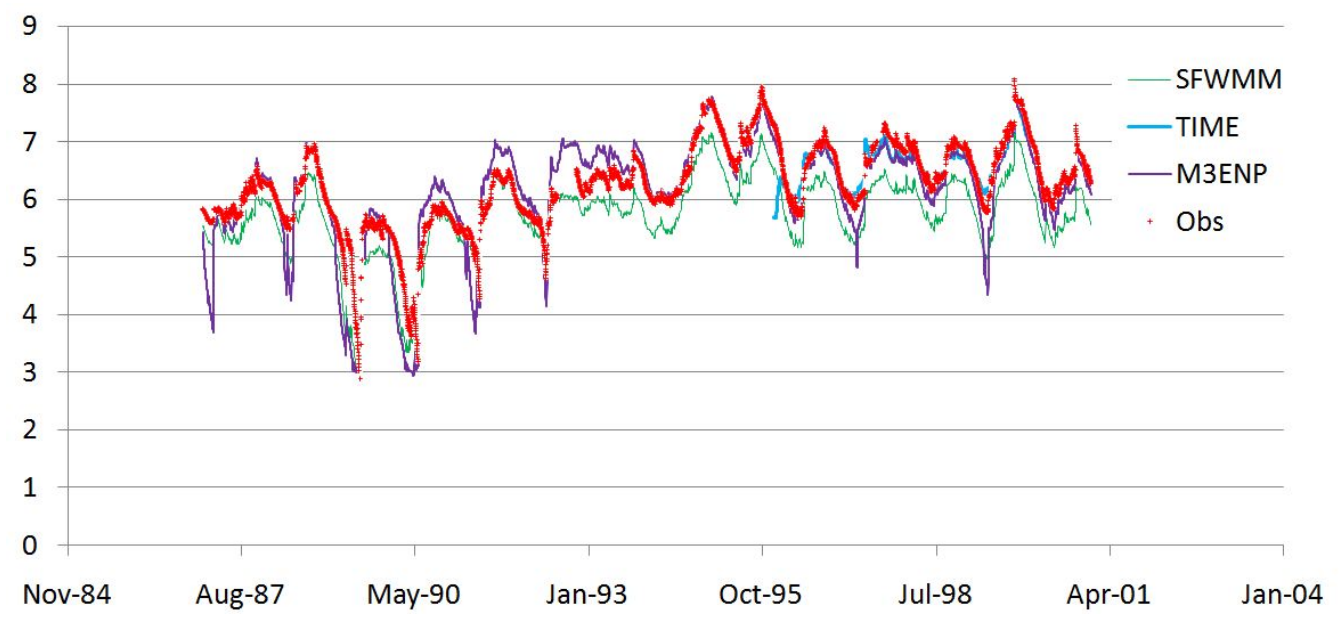

Figure 5.11: Comparison with other models: P33, Shark Slough. Y-axis represents the water elevation in feet.

\subsubsection{Rocky Glades}

In the northern Rocky Glades, local rainfall and water levels in L-31N determine the height of water levels. Pinelands in the south of the basin are more than a foot higher in elevation than the surrounding area. South of the Pinelands, the marsh vegetation is controlled by local rainfall and runoff from the Pinelands. Water management operations in the north have little effect on the hydrology. 


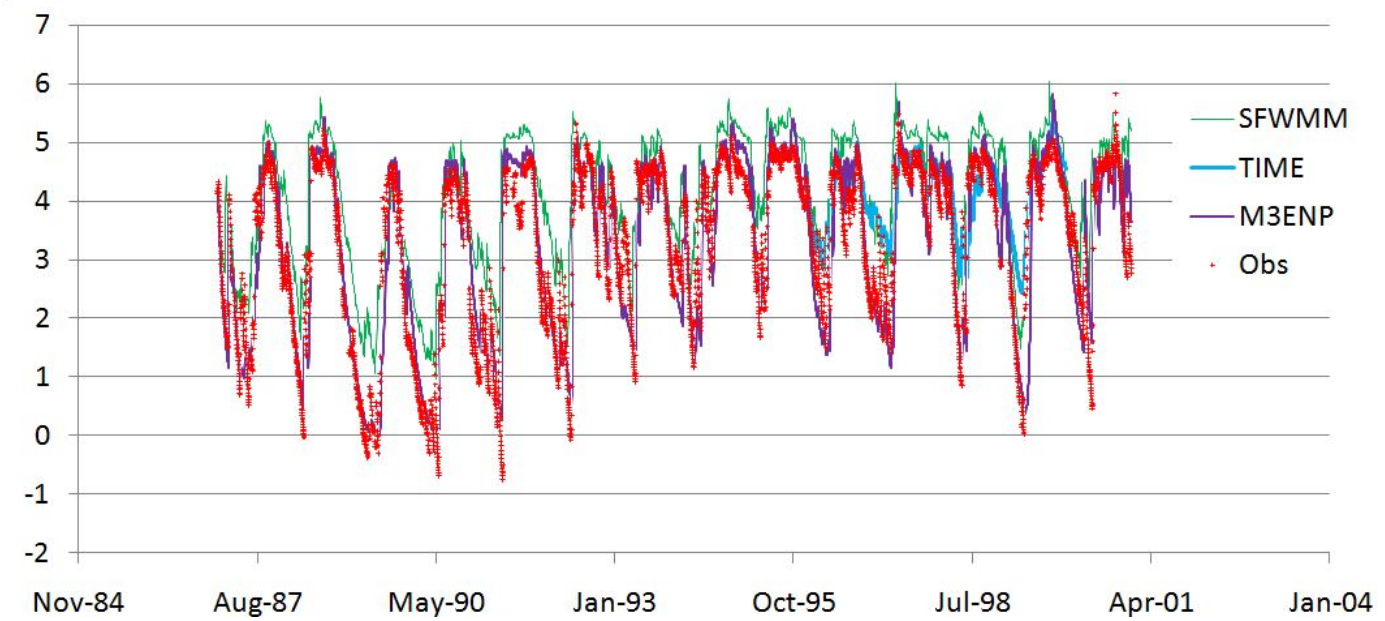

Figure 5.12: Comparison with other models: NP44, Rocky Glades. Y-axis represents the water elevation in feet.

\subsubsection{Taylor Slough Basin}

The Taylor Slough Basin is located west of southern Miami-Dade near the end of the South Dade Conveyance system. The basin receives discharge from L-31N via L-31W until S332 was moved to S332D. C-111 discharges to the East Panhandle of ENP. This area includes Park Road which impedes flow to the south. Taylor Slough discharges to the wetlands just north of Florida Bay.

The limitation that large grid cells introduce to studying ENP are shown Figure 5.13. The SFWMM has grid cells of 2 mile by 2 mile. The low resolution creates a limitation, especially at station NP67 in Taylor Slough, where there is natural shallow area bordered by higher elevations. Computer models assume uniform conditions over the area of each grid cell for calculations. For the large grid size of the SFWMM this means the computed water levels at NP67 are added to an elevation higher than station NP67. The SFWMM has a good match to the cyclic patterns of the observed data, but at higher levels. 


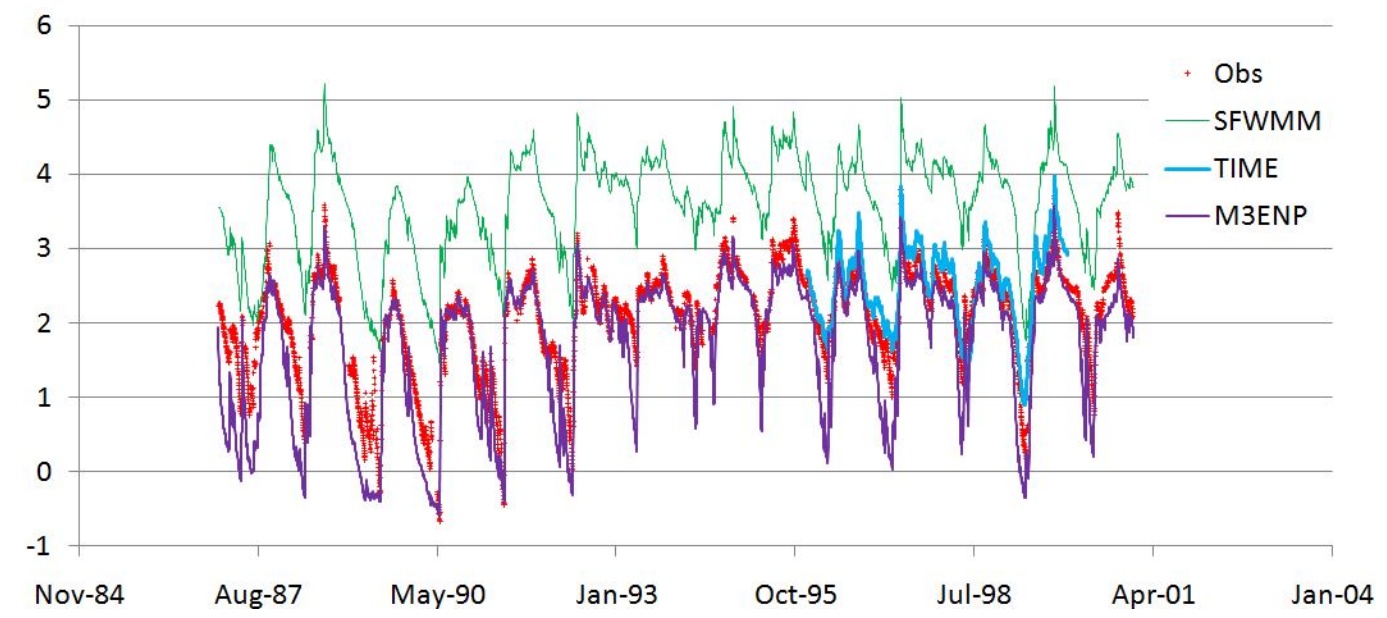

Figure 5.13: Comparison with other models: NP67, Taylor Slough Basin. Y-axis represents the water elevation in feet. 


\section{CHAPTER 6 CONCLUSIONS AND RECOMMENDATIONS}

This study resulted in the development of a modeling tool with an enhanced predictive capability, compared to other tools currently available, to simulate the flow regimes of ENP. The model includes a one-dimensional canal package with accurate cross sections, critical for the detention areas. Furthermore, the model includes detailed structure operation rules which control the primary water conveyance and drainage system in South Florida. The model addressed limitations of previously developed models by using a finer spatial resolution, a defined surface-subsurface interaction with known infiltration and seepage rates, and module for implementation of the canal network. The model has a $400 \mathrm{~m}$ grid resolution, control structures, a simplified subsurface system with only two layers, and a greater number of hydrological parameters impacting the the flow regime in ENP. In addition, the model run times were significantly reduced, compared to previous models, with simulations of 19 years being completed in approximately 12 hours. This hydrological model tool can be used to evaluate structural and operational alternatives important to ENP resources and restoration efforts.

Results of model simulations were used to answer a number of specific objectives. The models water balance accurately reproduced observed regional patterns and provided detailed daily time series of each component. First, the model showed the three main components which have the greatest influence on the regional hydrology are RF, the high hydraulic conductivity of the SZ, and ET. However, it also simulated that the degree of impact depends on the physical components of the area. For example, near the canal network, seepage has a greater impact than the ET compared to areas rich in vegetation. The model showed the subsurface flow components are largely lateral, into and out of the model domain. Horizontal 
flow is significantly larger and more critical than the vertical flow component to understanding the behavior of water within ENP. The water distribution between the surface and subsurface layers include the exchange of overland flow into and out of the canal network and the seepage of water in the canal network laterally and vertically into the subsurface. The current flow of water through ENP, according to daily hydrological events, such as RF and ET, and the vegetation and soil components in the model, predominantly follows a southwest path through a small portion of Shark Slough with significant seepage along the east side of the domain which flows out of the Park.

Recommendations include further implementation of restoration features and water quality components to enhance the representation of the physical system. This would include expansion of the model domain, incorporation of new structural features, such as the C-111 spreader project and the bridging of Tamiami Trail, including a water quality and sediment transport module, and increasing the simulation period to include time series from 2006 through 2010.

A water quality and sediment transport module would simulate water quality constituents, such as salinity and total phosphorus fluxes within ENP and relevant canals. The model could implement transport interactions between the rivers, canals, wetlands, reservoirs, detention areas, estuaries, and coastal waters, and simulate the spatial distribution of concentrations based on the chemical and physical processes. With the expansion of the model domain and inclusion of the water quality and sediment transport module, the model would provide a more comprehensive analysis on the hydrology and distribution of important chemical constituents.

Furthermore, the model can be applied to analyze the changing boundary conditions related to rising sea levels and greater tidal variations. Rising sea levels will impact the hydrology of the region and the spatial and temporal distribution of 
water fluxes between the surface/subsurface sub-domains of the hydrological cycle. Inland storms will create a greater flooding potential since the drainage system will have a more sluggish response. Information obtained from the model would provide a greater understanding of the flooding potential within the domain. The model can be used to determine the dynamics of the system for extreme hydrological events (extreme storms and precipitation). Based on the high permeability of the Biscayne Aquifer in the Miami-Dade County area, canals within the proposed domain have a direct impact on water levels in adjacent areas. Rising sea levels would affect the drainage capacity of the canals which manage the surface waters of ENP. Elevated sea levels will reduce the hydraulic slopes of the canals and decrease their conveyance capacity, which will require modification of structure operations. The model could aid in the decision making for the necessary modifications. 


\section{REFERENCES}

[1] United States Army Corps of Engineers (USACE). "Final Revised General Reevaluation Report/Second Supplemental Environmental Impact Statement (RGRR/SEIS) for the Tamiami Trail Modifications Modified Water Deliveries to Everglades National Park", 2005.

[2] Grunwald M. The Swamp: The Everglades, Florida, and the Politics of Paradise. New York, NY: Simon \& Schuster Paperbacks, 2006.

[3] Lodge T.E. The Everglades Handbook. CRC Press, Boca Routon, FL, 2nd edition, 2005.

[4] South Florida Water Management District. "Final Peer Review Report for the South Florida Water Managment Model Version 5.5". Technical report, Hydrologic \& Environment Systems Modeling Department, West Palm Beach, FL, 2005.

[5] United States Geological Survey. "The Tides and Inflows in the Mangroves of the Everglades (TIME) Interdisciplinary Project of the South Florida Ecosystem Program, Fact Sheet FS-031-01". Technical report, U.S. Department of the Interior and U.S. Geological Survey, 2001.

[6] South Florida Water Management District. Structure Books, Revised 6/15/94. Operations Control Center (OCC), West Palm Beach, Florida, 1994.

[7] Jacksonville District U.S. Army Corp Of Engineers. System Operating Manual. Jacksonville, Florida, December 2005.

[8] GOOGLE EARTH. "Everglades National Park, FL", January 2010.

[9] Fish J.E. and Stewart M.T. "hydrogeology of the Surficial Aquifer System, Dade County, Florida: U.S. Geological Survey Water-Resources Investigations Report 90-4108", 1991.

[10] Reese R.S. and Cunningham K.J. "Hydrogeology of the Gray Limestone Aquifer in Southern Florida: U.S. Geological Survey Water-Resources Investigations Report 99-4213", 2000.

[11] Nemeth M.S., Wilcox W.M., and Solo-Gabriele H.M. "Evaluation of the Use of Reach Transmissivity to Quantify Leakage Beneath Levee 31N, Miami-Dade 
County, Florida, Water-Resources Investigations Report 00-4066". Technical report, U.S. Geological Survey, 2000.

[12] Natural Resources Conservation Service Soil Survey Staff. United States Department of Agriculture. Soil Survey Geographic (SSURGO) Database for Miami-Dade County, Florida. http://soildatamart.nrcs.usda.gov.

[13] Natural Resources Conservation Service Soil Survey Staff. United States Department of Agriculture. U.S. General Soil Map (STATSGO2). http://soildatamart.nrcs.usda.gov.

[14] U.S. Geological Survey. Eastern Geographic Science Center, Miami-Dade County FL Soil Map. http://sofia.usgs.gov/exchange/jjones/jjones.html, 2006.

[15] Jones J.W. "Creation of GIS-Compatible, Historic Detailed Soil Data for Collier and Miami-Dade Counties, Florida: USGS Open-File Report 2006-1315, U.S. Geological Survey, Reston, VA", 2006.

[16] US Geological Survey. Gap Analysis Program (GAP), national land cover survey, 2010.

[17] Homer C., Huang C., Yang L., Wylie B., and Coan M. Development of a 2001 National Landcover Database for the United States. Photogrammetric Engineering and Remote Sensing, July 2004.

[18] Sklar F. H., Fitz H. C., Wu Y., van Zee R., and McVoy C. "South Florida: the Reality of Change and the Prospects for Sustainability: The Design of Ecological Landscape Models for Everglades Restoration". Ecological Economics, 37(3):379-401, June 2001.

[19] Brion L., Senarath S.U.S., Lal A.M.W., and Belnap M. "Application of the South Florida Regional Simulation Model in the Southern Everglades". Journal of Water Resources, Planning, and Management, 130(5):359, 2004.

[20] Walters C., Gunderson L., and Holling C. S. "Experimental Policies for Water Management in the Everglades". Ecological Applications, 2(2):189-202, May 1992.

[21] DeAngelis D. L., Gross L.J., Huston M.A., Wolff W.F., Fleming D.M., Comiskey E.J, and Sylvester S.M. "Landscape Modeling for Everglades Ecosystem Restoration". Ecosystems, 1(1):64-75, 1998. 
[22] Wilcox W. Geer 2008 Conference. "Regional Hydrologic Models 101 Modeling for Restoration Planning and Implementation, Use of the South Florida Water Management Model (SFWMM)". SFWMD, Naples, FL. 2008.

[23] Bahm K. and Fennema R. "Draft Application of the Time Model Version 2.0 to Everglades National Park Sea-Level Rise and Restoration Alternatives". South Florida Natural Resources Center, Everglades National Park, Homestead, FL, 2011.

[24] DHI Water \& Environment. MIKE 11, A Modelling System for Rivers and Channels, Reference Manual, 2011.

[25] Fennema R. and Bahm K. National Park Service, Personal Communication. Miami, FL. 2010-2012.

[26] U.S Army Corps of Engineers. "Design Modifications for the Canal 111 (C111) Project Miami-Dade County, Florida". Draft Environmental Assessment, Jacksonville Distict, June 2007.

[27] Harry Pepper and Associates Inc. "Record Drawing DACW17-02-C-0018 for IOP Emergency Contract Listin". Technical report, Deparment of the Army, Jacksonville Distict, Corps of Engineers, Jacksonville, Florida, April 2002.

[28] U.S Army Corps of Engineers. "C-111 Engineering Documentation Report". Technical report, U.S. Army Corps of Engineers, June 2007.

[29] DHI Water \& Environment. MIKE SHE User Manual Vol 2: Reference Guide, 2007.

[30] Kristensen K.J. and Jensen S.E. "A Model for Estimating Actual Evapotranspiration from Potential Evapotranspiration". Nordic Hydrology, 6:170-188, 1975 .

[31] Abtew W. "Evapotranspiration in the Everglades; Comparison of Bowen Ratio Measurements and Model Estimations". Technical report, South Florida Water Management District, July 2004. 